\title{
TECTONIC VERSUS VOLCANIC ORIGIN OF THE SUMMIT DEPRESSION AT MEDICINE LAKE VOLCANO, CALIFORNIA
}

by

\author{
Mark Leon Gwynn
}

A thesis submitted to the faculty of

The University of Utah

in partial fulfillment of the requirements for the degree of

\author{
Master of Science
}

Department of Geology and Geophysics

The University of Utah

May 2010 


\begin{abstract}
Medicine Lake Volcano is a Quaternary shield volcano located in a tectonically complex and active zone at the transition between the Basin and Range Province and the Cascade Range of the Pacific Province. The volcano is topped by a 7x12 km elliptical depression surrounded by a discontinuous constructional ring of basaltic to rhyolitic lava flows. This thesis explores the possibility that the depression may have formed due to regional extension (rift basin) or dextral shear (pull-apart basin) rather than through caldera collapse and examines the relationship between regional tectonics and localized volcanism. Existing data consisting of temperature and magnetotelluric surveys, alteration mineral studies, and core logging were compiled and supplemented with additional core logging, field observations, and fault striae studies in paleomagnetically oriented core samples. These results were then synthesized with regional fault data from existing maps and databases.

Faulting patterns near the caldera, extension directions derived from fault striae $\mathrm{P}$ and $\mathrm{T}$ axes, and three-dimensional temperature and alteration mineral models are consistent with slip across arcuate ring faults related to magma chamber deflation during flank eruptions and/or a pyroclastic eruption at about $180 \mathrm{ka}$. These results are not consistent with a rift or pull-apart basin. Limited subsidence can be attributed to the relatively small volume of ash-flow tuff released by the only known major pyroclastic eruption and is inconsistent with the observed topographic relief. The additional relief can be explained by constructional volcanism. Striae from unoriented and oriented core,
\end{abstract}


augmented by striae measurements in outcrop suggest that Walker Lane dextral shear, which can be reasonably projected from the southeast, has probably propagated into the Medicine Lake area. Most volcanic vents across Medicine Lake Volcano strike northsouth, suggesting they are controlled by crustal weakness related to Basin and Range extension. Interaction of dextral shear, Basin and Range extension, and the zone of crustal weakness expressed as the Mount Shasta-Medicine Lake volcanic highland controlled the location and initiation of Medicine Lake Volcano at about $500 \mathrm{ka}$. 


\section{CHAPTER 1}

\section{INTRODUCTION}

\section{$\underline{\text { Geologic Setting and Background }}$}

Medicine Lake Volcano (MLV) is a large Quaternary shield volcano located approximately $50 \mathrm{~km}$ ENE of Mt. Shasta on the eastern flank of the Cascade Range in northern California (Figs. 1.1; 1.2). The volcano lies atop older lavas of the Modoc Plateau, an extensive volcanic highland developed in an extensional setting at the transition between the Basin and Range Province and the Cascade Range of the Pacific Province (Fig. 1.2) (Lutz et al., 2000; Hildreth, 2007). No basement rocks are exposed on the Medicine Lake Highland (Hausback, 1984), but the basement beneath the Modoc Plateau is believed to consist of granitic and metamorphic rocks representing the roots of at least one magmatic arc (Fuis et al., 1987). This theory is supported by the crustal structure model proposed by Ritter and Evans (1997).

The summit of Medicine Lake Volcano and a large portion of the shield are encompassed by the Glass Mountain Known Geothermal Resource Area (KGRA). It is

the largest known commercially producible, yet undeveloped, geothermal resource in the United States (Moore, 2004). The area is leased by Calpine-Siskiyou Geothermal Partners LP, a subsidiary of Calpine Corporation (Moore, 2004). The KGRA covers an area of approximately $543 \mathrm{~km}^{2}$ (BLM, 1999). The $104 \mathrm{~km}^{2}$ Glass Mountain Federal Geothermal Unit is located at the summit of MLV and is enclosed by the KGRA (BLM, 1999). 


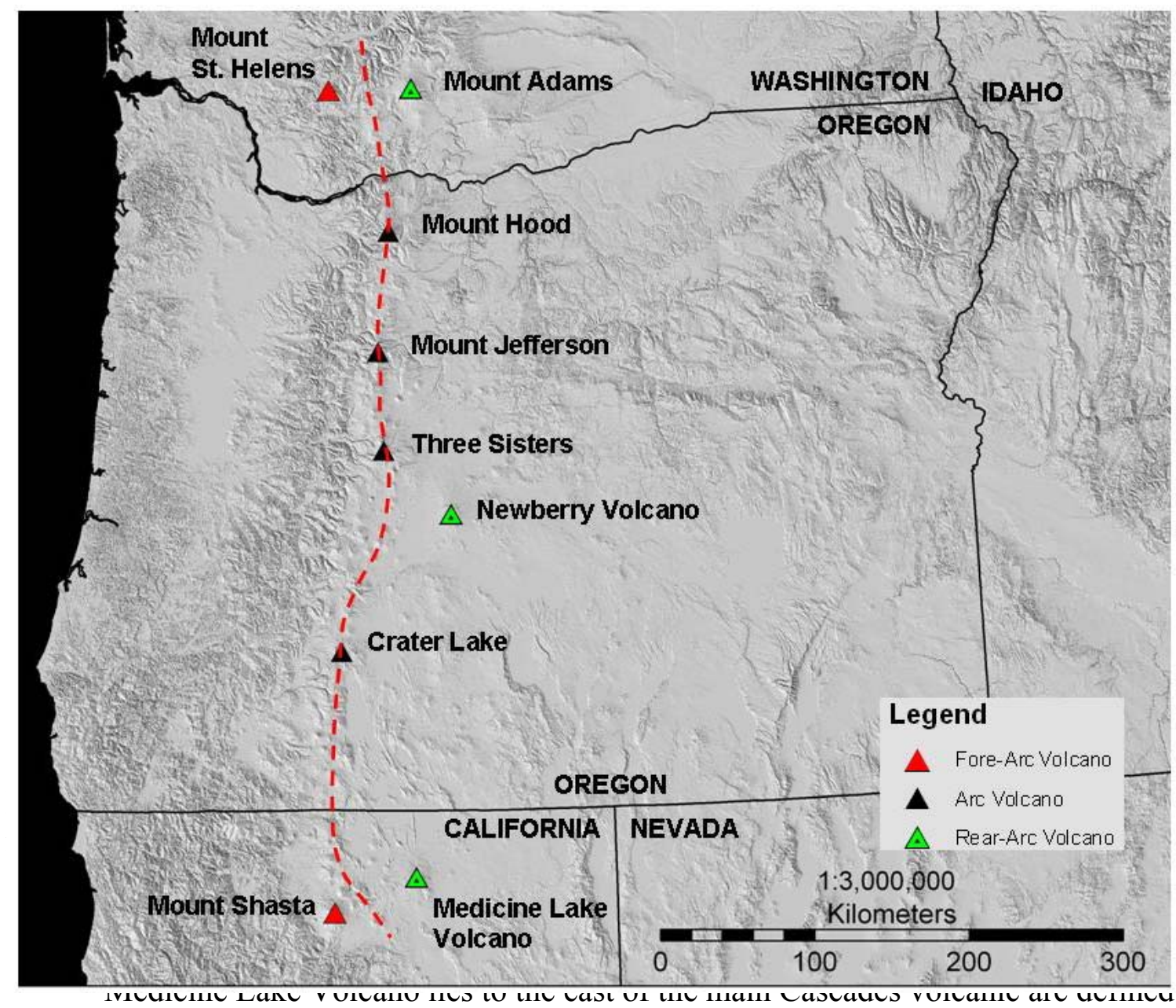

by the linear alignment of primarily mafic cones, shields, and stratovolcanoes of the

Cascade Range (Fig. 1.1) (Donnelly-Nolan et al., 2008). Because of this association, Donnelly-Nolan et al. (2008) classify MLV as a Cascades rear-arc volcano. In contrast, Hildreth (2007) believes the volcano is more properly classified as a rear-arc volcanic field related to Basin and Range extension. Much of this conflict relates to the existence at MLV of basalts with chemical compositions related to both subduction zone volcanism 


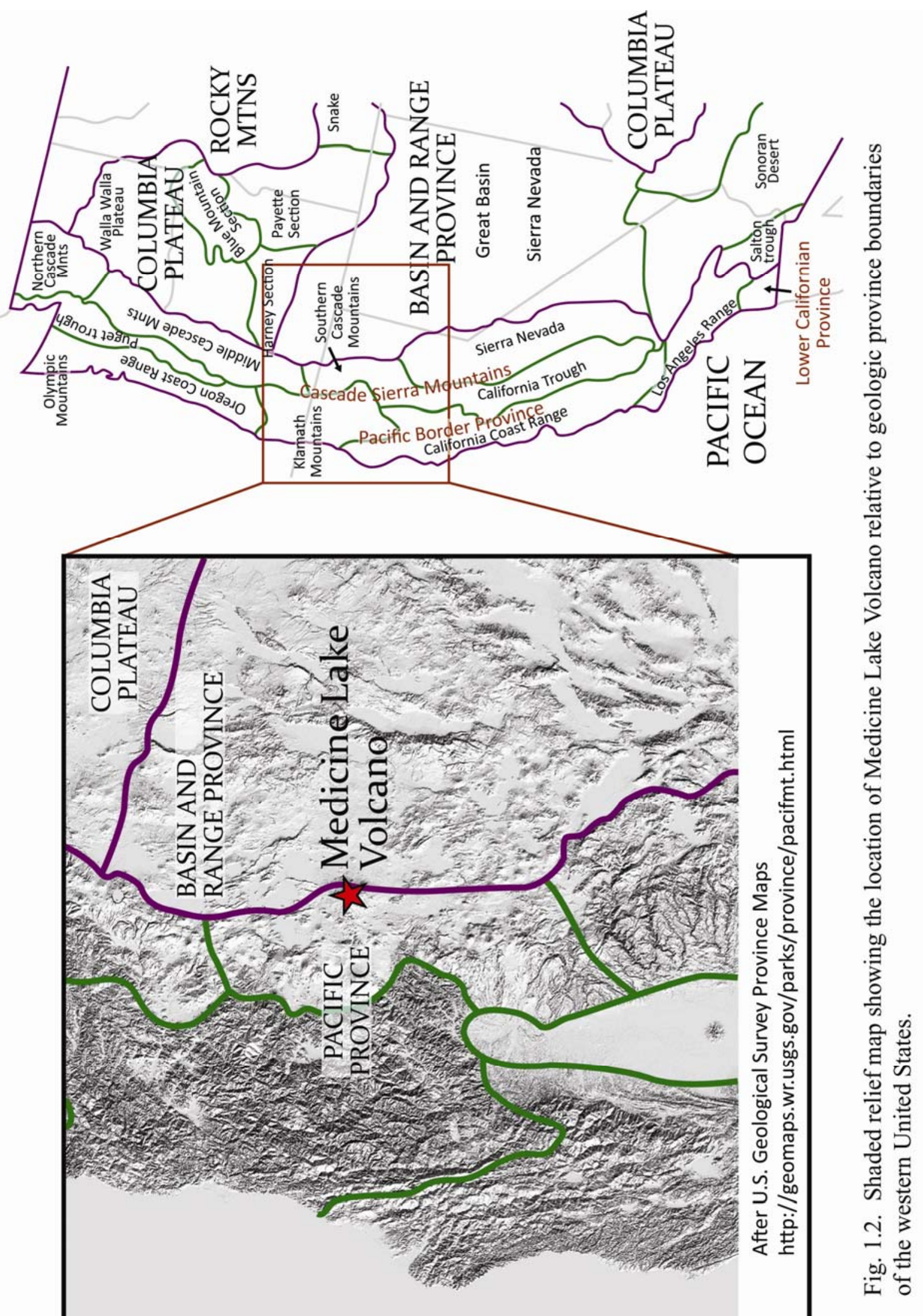


and extensional volcanism. Calcalkaline basalts containing trace element signatures and high pre-eruptive water contents suggest a subduction origin (Donnelly-Nolan et al., 2008). However, low- $\mathrm{K}_{2} \mathrm{O}$ primitive high-alumina olivine tholeiite (HAOT) basalts, associated with Basin and Range extension, are also found (Donnelly-Nolan et al., 2008). Certainly, there are differences between MLV and the typical Cascades volcano. Anderson (1941) noted that “... Medicine Lake volcano differs in many respects from the main cones of the High Cascades, and is more similar to the Newberry volcano of central Oregon, which is also built upon a lava plateau to the east of the High Cascades." Donnelly-Nolan et al. (2008) concur that Newberry Volcano, along with Mount Adams, are analogous to MLV. The extensive linear arrays of vents at Medicine Lake Volcano appear to be related to extensional faulting, and are an important parts of Hildreth's (2007) interpretation. Newberry and Medicine Lake volcanoes may be subductionrelated, but have been greatly influenced by their location in an extensional tectonic environment (Donnelly-Nolan, 1990; Donnelly-Nolan et al., 2008).

Medicine Lake Volcano forms a broad shield with an area of about $2200 \mathrm{~km}^{2}$ (Donnelly-Nolan et al., 2008). The summit has an elevation of 2376 meters, some 1200 meters above the surrounding Modoc Plateau (Dzurisin et al., 1991). The volcano is topped by a shallow elliptical depression measuring approximately $7 \times 12$ kilometers. The summit depression contains Medicine Lake and is surrounded by a discontinuous constructional ring of basaltic to rhyolitic flows (Lutz et al., 2000). Although there is no visible outlet, the water of Medicine Lake is fresh, apparently seeping through the floor of the basin (Anderson, 1941). Measurements from thermal gradient boreholes and production-temperature wells define an area of approximately $104 \mathrm{~km}^{2}$ with temperatures 
in the range of $260^{\circ} \mathrm{C}$ at depths of less than $1220 \mathrm{~m}$ (Moore, 2004). Despite the large area and high temperatures, the only surficial manifestation of the geothermal system is a weak fumarole known as the Hot Spot (Fig. 1.3) (Moore, 2004).

The lavas of the volcano extend more than $80 \mathrm{~km}$ on a north-south line with an east-west dimension slightly under $50 \mathrm{~km}$ (Donnelly-Nolan et al., 2007). These lavas are assigned to 208 mapped volcanic rock units that cover over $95 \%$ of the MLV area (Smith and Donnelly-Nolan, 2005; Donnelly-Nolan et al., 2008).

Smith and Donnelly-Nolan (2005) mapped 525 volcanic vents 0-2 Ma in age in the MLV area. They also concluded that the vents for an additional 56 volcanic rock units are unknown or buried. Since most mapped units were linked to multiple vents (Smith and Donnelly-Nolan, 2005), it is likely that the total number of vents greatly exceeds 600. The vents cover an area of about $55 \mathrm{~km} \mathrm{~N}-\mathrm{S}$ and $40 \mathrm{~km} \mathrm{E-W}$, although vents related to post-glacial eruptions are roughly $34 \mathrm{~km} \mathrm{~N}-\mathrm{S}$ and $19 \mathrm{~km} \mathrm{E-W}$ (DonnellyNolan et al., 2008). Groups of multiple vents are commonly aligned parallel or subparallel to faults and regional structures, resulting in the majority being aligned within $30^{\circ}$ of north (Donnelly-Nolan et al., 1990). This association implies tectonic control of vent location. However, the alignment of some vents on the southwestern flank trend $045^{\circ}-055^{\circ}$ and may be related to the volcanic highland between Mount Shasta and Medicine Lake Volcano (Donnelly-Nolan et al., 1990). Additionally, the alignment of some vents appears to be controlled by localized edifice effects (Hildreth, 2007). The oldest known Medicine Lake Volcano lavas were erupted about 500 ka (DonnellyNolan and Lanphere, 2005), and hundreds of eruptions have occurred since then (Donnelly-Nolan et al., 2007). The most recent eruptive period spans the last 12,000 


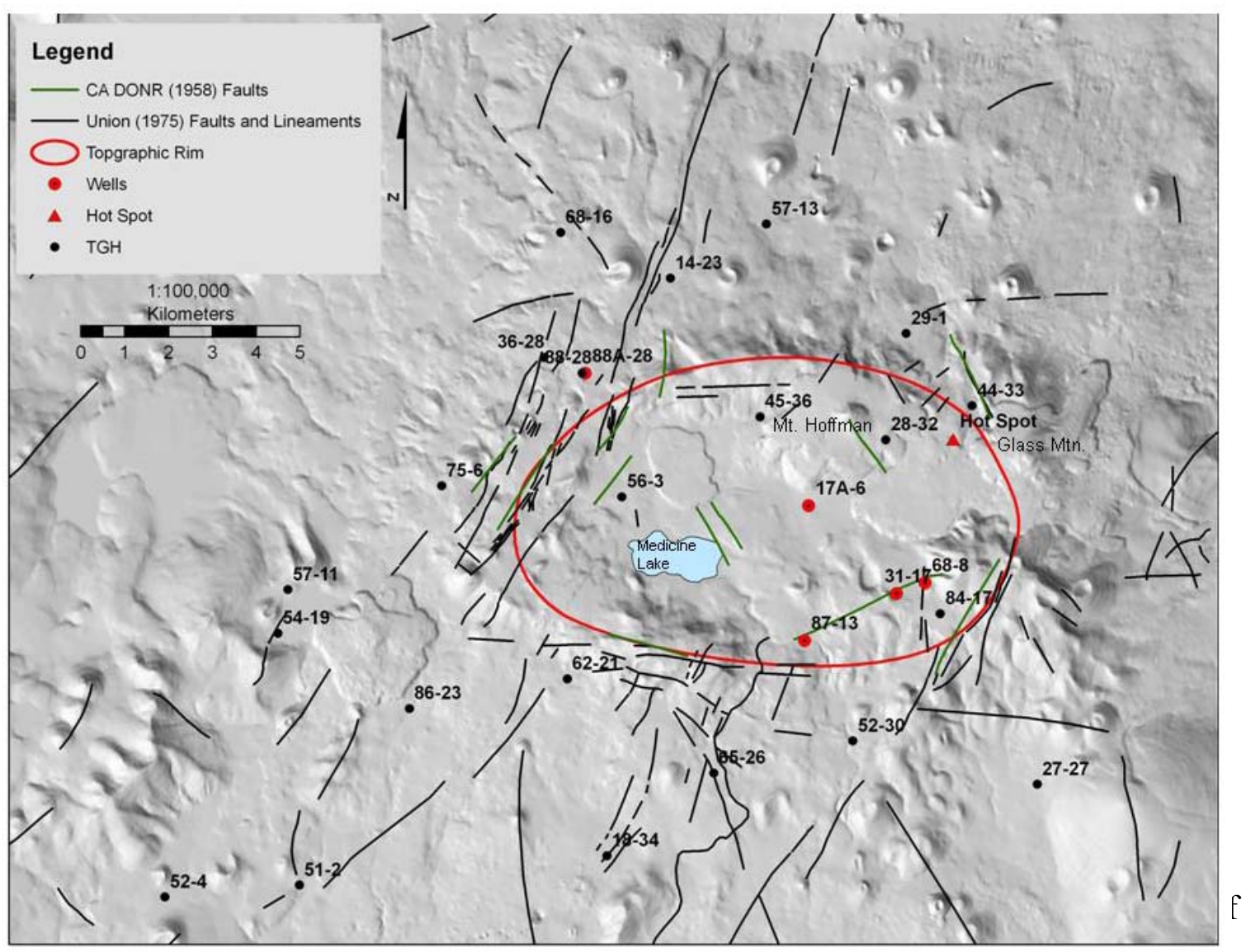

the mapped rock units (Donnelly-Nolan, 1990). Nine of these events occurred in the last

5,200 years, yielding one of the highest eruption frequencies among the volcanoes of the Cascade Range (Donnelly-Nolan et al., 2007). Lava composition ranges from basalt to rhyolite (Donnelly-Nolan et al., 2007). High-silica rhyolites and dacites have generally been erupted from the upper portions of the volcano, while mafic flows of basalt, basaltic andesite, and andesitic compositions are more common around the flanks of the volcano (Donnelly-Nolan et al., 2007). The silicic flows were viscous and typically advanced no more than a few kilometers, whereas the mafic flows were more fluid and when erupted from multiple vents may cover up to $300 \mathrm{~km}^{2}$ (Donnelly-Nolan, et al., 2007). Although the mafic lavas typically flowed smoothly, the initial eruptive period was often characterized by pyroclastic activity that formed cinder or spatter cones (Donnelly-Nolan 
et al., 2007). The volume of MLV lavas is estimated to be $600 \mathrm{~km}^{3}$ (Donnelly-Nolan, 1988), greater than the largest Cascades stratocone, Mt. Shasta (Donnelly-Nolan, 1990). The shield appears to be composed largely of mafic lavas, but drillhole data show there is more rhyolite present than geologic mapping indicates (Donnelly-Nolan, 1990).

Shallow plutonic granodiorite was penetrated by well GMF 17A-6 (Carrier, 1989a). Granodiorite is found as dikes and sills in well GMF 31-17 (Carrier, 1989a). Studies of hydrothermally altered granodiorite from GMF 31-17, along with altered and unaltered granitoid xenoliths from volcanic units at MLV, led Lowenstern et al. (2003) to conclude that an approximately $320 \mathrm{ka}$ granitic intrusion, possibly greater than $6 \mathrm{~km}$ in diameter, may be present beneath the volcano. Based on the spatial distribution of lava flows containing granitic inclusions and the drilled thickness, Donnelly-Nolan et al. (2008) estimate the intrusive body to be larger than the topographic rim with a volume that may exceed $200 \mathrm{~km}^{3}$. This estimate agrees with the gravity model of Finn and Williams (1982), who infer a shallow intrusive body with a possible areal extent of $28 \mathrm{~km}$ on an E-W line and $15 \mathrm{~km}$ on a N-S line is present. Uranium-Thorium disequilibrium ages of zircons from six unaltered granitoid xenoliths found in lavas around the MLV summit suggest that multiple intrusions have been emplaced over the last 0-200 ka (Lowenstern et al., 2003). Additionally, seismic refraction, magnetotelluric, and tomographic methods have been used by a number of geoscientists to infer the presence of shallow plutonic rocks beneath the volcano (Donnelly-Nolan et al., 2008).

The silicic flows at the summit of the dominantly mafic volcano have led some researchers to conclude that a moderately large silicic magma chamber may be present beneath MLV. Eichelberger (1981) proposes a long-lived magma chamber at less than 
$10 \mathrm{~km}$ depth based on apparent mixing of mafic and silicic magmas that were extruded at Glass Mountain. Low-velocity features inferred through seismic tomography studies suggest a small stratified magma chamber is present on the eastern side of the summit depression at about 3-5 km depth (Evans and Zucca, 1988; Chiarabba et al., 1995). Two recent long-period earthquakes at 13-15 km depth beneath MLV may indicate magma migration (Dzurisin, 1991; Pitt et al., 2002 as cited in Donnelly-Nolan et al., 2007). There is evidence that there is some degree of dextral shear, likely an extension of the Eastern California Shear Zone and Walker Lane belt (Figs. 1.4; 1.5), present in the MLV area. The Likely Fault Zone southeast of MLV primarily accommodates dextral shear (Sawyer and Bryant, 1995). Blakely et al. (1997) compared regional gravity anomalies, fault orientations, and vent density and location to infer that the northwest trending faults reflect the propagation of dextral shear strain from the Walker Lane belt into the Cascades arc in Oregon. Field measurements based largely on striated fractures in the MLV area indicate substantial components of primarily dextral strike slip shear (Nemčok, Energy and Geoscience Institute, unpublished data, 2006). However, Wesnousky (2005) states he is unaware of any estimates of dextral offset for the Northern California Shear Zone where MLV resides. Faulds et al. (2005) believe that the approximately 50-100 km of dextral offset observed in southern California essentially drops to zero at the northwestern terminus of the Walker Lane belt, roughly $100 \mathrm{~km}$ south of MLV. 


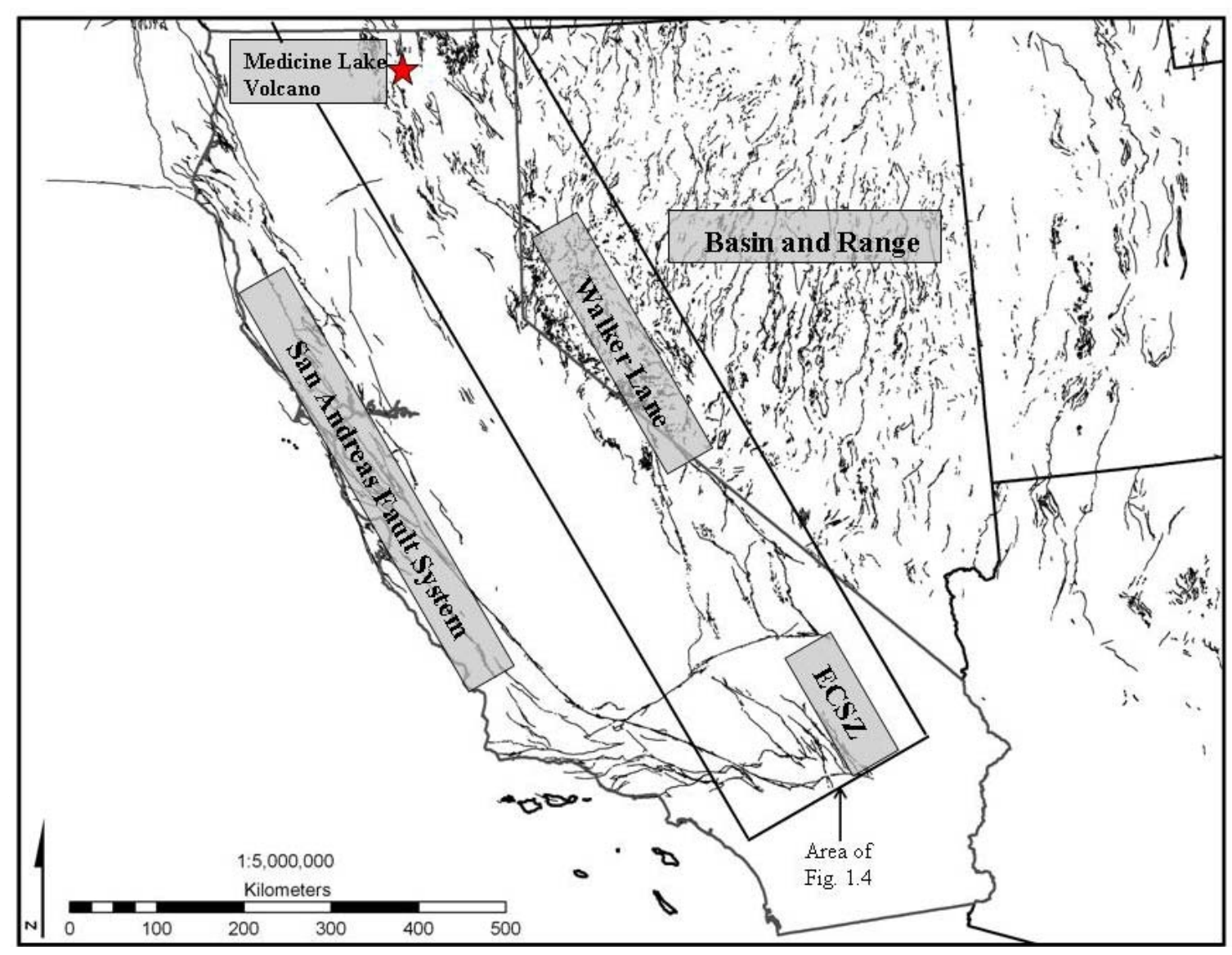




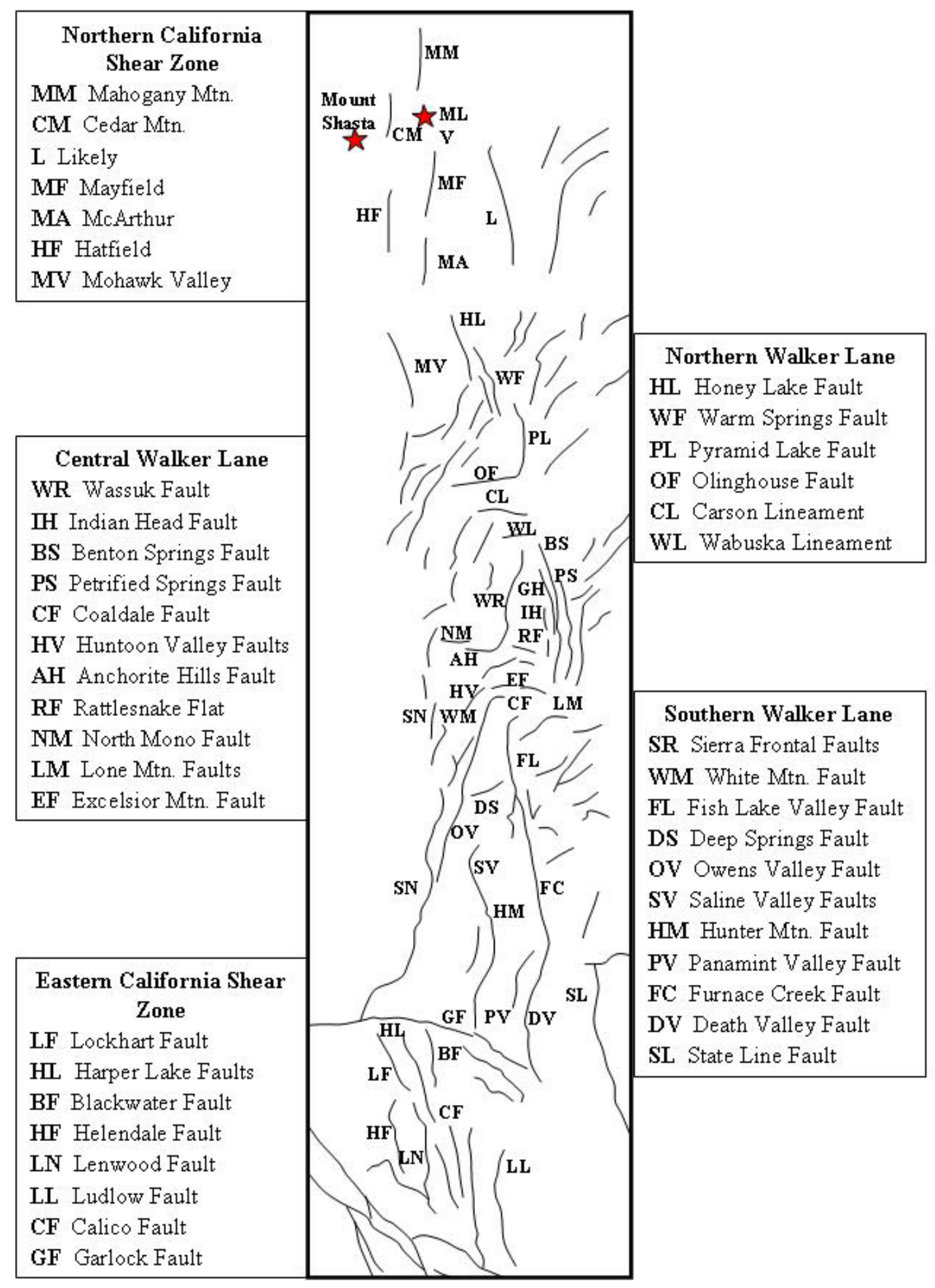

Figure 1.5. Active faults of the Walker Lane fault system (after Wesnousky, 2005). 


\section{$\underline{\text { Previous Work and Data Sources }}$}

Studies by Peacock (1931) and Powers (1932), followed by Anderson's classic 1941 study constitute much of the early geologic and petrologic work on Medicine Lake Volcano (Donnelly-Nolan, 1988). A three-decade hiatus then followed before new geological and geophysical techniques contributed to renewed geologic interest in the area (Donnelly-Nolan et al., 2008). The potential for Medicine Lake Volcano to become an economically viable source for geothermal power generation was a major factor in the renewed effort, although research into the possibility of renewed volcanic activity and other motives were also involved. However, the robust exploration and pre-production drilling programs driven by the energy industry have yielded the majority of the new data.

The California Division of Oil, Gas, and Geothermal Resources electronic database (http://www.conservation.ca.gov) lists 59 boreholes in the MLV area. Of these, most are Temperature Gradient Holes (TGH), although several other types, including production-capable wells, are listed. Three additional TGH wells and another exploratory water test hole have been proposed. Known spud dates (commencement of drilling operations) range from October 9, 1981 to July 21, 2002, with most drilled during the 1980's. By convention, wells and boreholes using the designation of "GMF" were drilled within the Glass Mountain Federal Geothermal unit, while those with an "ML" designation were drilled elsewhere in the Glass Mountain KGRA. Figure 1.3 depicts the TGH and wells used in this study.

Core from 18 of the Medicine Lake area boreholes is stored at the sample library of the Energy and Geoscience Institute (EGI) at the University of Utah. This collection 
contains over 17,500 $\mathrm{m}$ of core and cuttings from the Medicine Lake Volcano area. In addition to core and cuttings, a vast and comprehensive suite of data is available, including various downhole surveys, well test data, geochemical analyses, geophysical surveys, and other geologic data (Moore, 2004). Most of the data were collected by Union Oil Co., Phillips Petroleum Co., CalEnergy Co., and the Calpine Corporation (Moore, 2004). A significant portion of these data sets is proprietary, but was released to EGI for U.S. Department of Energy (DOE) funded research projects, of which this thesis is a component (Moore, 2004).

\section{Hypotheses for the Origin of the Summit Basin of MLV}

The most common explanation for the formation of the summit depression is that it is a caldera (Anderson, 1941; Eichelberger, 1981; and Donnelly-Nolan et al., 2008). Others have challenged this interpretation. Hulen and Lutz (1999) acknowledge the traditional interpretation, but find little evidence of large-scale collapse despite obvious ring-fracture volcanism based on drilling data. Nordquist and Thompson (1990) believe there is no significant evidence for the required subsurface offset beneath the volcanic rim and that the minimal accumulations of tuff do not support a collapse hypothesis. They do propose, however, that the elliptical pattern of vents around the central intrusion may indicate incipient caldera collapse. The 180 ka dacite ash-flow tuff of Antelope Well is the only tuff known to have erupted from MLV (Donnelly-Nolan et al., 2007, 2008). According to Donnelly-Nolan et al. (2007), the single large pyroclastic eruption that generated this tuff contributed to caldera formation and formed deposits that are present in all areas of MLV. A rough estimate of the volume of the tuff is $2 \mathrm{~km}^{3}$ (DonnellyNolan, 1983 as cited in Hausback, 1984). This volume is small enough to contradict a 
major collapse as the mechanism responsible for the summit depression (Hausback, 1984; Joseph Moore, Energy and Geoscience Institute, personal communication). If the summit depression was not formed by caldera collapse, then it must have formed through a tectonic mechanism. Medicine Lake Volcano is located near the boundary of the extensional Basin and Range province and north-south trending normal faults are present in and around the volcano (Donnelly-Nolan et al., 1990; Dzurisin, 1991; Blakely et al., 1997; Clausen et al., 2006). As noted previously, there may be a component of dextral shear across the MLV area. Indeed, the Walker Lane belt of dextral shear can reasonably be projected into the Medicine Lake area. Therefore, it is reasonable to hypothesize that the depression could be caused by east-west extension, northwestsoutheast trending strike-slip movement resulting in a pull-apart basin, or a combination of these.

Therefore, five hypotheses for the origin of the observed structure were developed and tested in this thesis: 1) simple collapse caldera, 2) orthogonal rift basin, 3) orthogonal rift dominated by a caldera, 4) pull-apart basin, and 5) pull-apart basin dominated by a caldera. Each of these possible structural hypotheses will produce a different fault pattern and stress distribution.

Fault patterns are an important part of determining the relationship between regional tectonics and the formation of the topographic rim at MLV. Unfortunately, the lavas flowing from a fault-related vent tend to cover adjacent fault segments (Dzurisin et al., 1991). It is also important to determine fault-related structures at depth. This work integrates a number of models and data sets to help determine the location of faults that may be covered, characterize the probable fault orientations at depth, and examine the 
kinematic signatures beneath the MLV summit in order to determine which hypothesis is most correct.

The primary data sets include: 1) Core logging from nine TGH and wells in the Glass Mountain KGRA. 2) Fracture orientations from selected paleomagnetically oriented intervals of the logged cores. From these, the contraction $(\mathrm{P})$ and dilation $(\mathrm{T})$ axes are used to determine the kinematics of the fracture zones. 3) Field measurements and observations made by Dr. Michal Nemčok and Dr. Joseph Moore of EGI. 4) Calculations of expected fault dips based on the bulk lithology observed during core logging. 5) Magnetotelluric (MT) maps created for selected elevation slices through the volcano. 6) Regional fault data from the USGS Quaternary Fault and Fold database and various geologic maps.

The models include: 1) A 3-D model of six isothermal temperature zones at depth. Interpretation of this model is based on the premise that faults and fracture zones allow heated fluids to migrate toward the surface, creating high-temperature perturbations at shallower depths. Cooling intrusions may also produce such perturbations. Since such intrusions are likely to migrate upward along zones of weakness, they may delineate fault zones in the same manner. +2) A 3-D model based on the shallowest occurrences of a number of hydrothermal alteration minerals. The idea behind this model is similar to the temperature models in that fracture and fault zones create localized zones of increased permeability that allow heated fluids to flow and to precipitate minerals. 


\section{CHAPTER 2}

\section{METHODS}

\section{Quality Checks of Existing Data}

The first geothermal exploration well on Medicine Lake Volcano was drilled in 1981. Since then, many other wells and coreholes have been drilled, providing large volumes of many types of data, including X-Ray Diffraction (XRD), rock core, and temperature-depth profiles. These datasets represent a large portion of the data used in this thesis.

Several scientists and students at EGI have previously compiled much of this data into spreadsheets for entry into various computer programs. When the temperature surface models using Petrel (Schlumberger, 2007, Version 2007.1.2) were constructed using data from some of these spreadsheets, several unusual and geologically unrealistic results were discovered. The problems were traced to a "cut-and-paste" error in a source spreadsheet. Additionally, the source of the original data was not noted on many of the spreadsheets. Therefore, it was critical to perform quality control checks to assure data integrity and properly document data sources. Consequently, the data sets for all pertinent wells were reviewed and crosschecked for accuracy using original documentation, once determined, as well as reports from earlier studies. A small number of additional typographical or "cut-and-paste" errors were discovered and corrected. 


\section{Core Logging}

Nearly 9,300 meters of core from 9 wells within the Glass Mountain KGRA were analyzed for the DOE-funded project of which this thesis is a part. Core logging was accomplished over a period of several years by EGI scientists and students including Jeffrey Hulen, Michal Nemčok, Joseph Moore, Steven Clausen, Emily Jackson, and Mark Gwynn. The wells were selected based on their locations with respect to anticipated rift or pull-apart bounding faults and inner and outer portions of the inferred caldera (Figs. 1.3 and 2.1). The wells were logged with emphasis on lithology, fracture orientation and density, degree and type of pore and fracture mineralization, evidence of fracture reactivation, and slip type (dip, strike, or oblique) defined by shear striae. Core segments suitable for paleomagnetic orientation were also identified. Each fracture was evaluated to determine whether it was natural or drilling-induced. Mineralized fracture surfaces and those with slip striae were interpreted to be natural, while those lacking either of these features were interpreted to be the result of drilling and were excluded from the dataset.

\section{Fracture Measurements in Paleomagnetically Oriented Core}

Continuous core segments with at least four shear fractures were identified during the core logging study by Steven Clausen. Ten of these core intervals from GMF 88-28, GMF 28-32, ML 14-23, GMF 87-13, and ML 62-21 were selected for paleomagnetic orientation by Dr. David Van Alstine of Applied Paleomagnetics, Inc. (Table 2.1). 


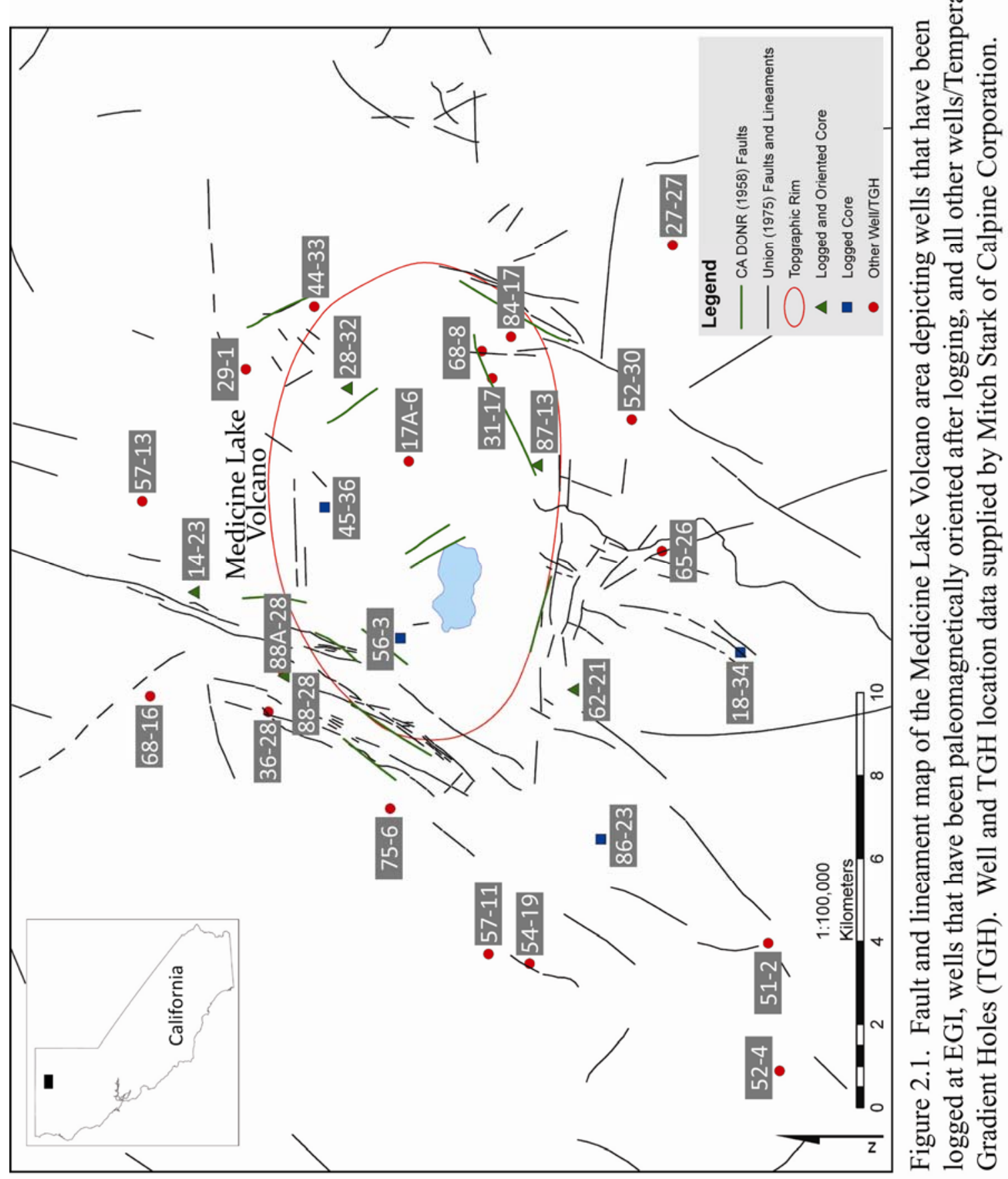


Table 2.1

Depth, elevation, and polarity of paleomagnetically orientated core intervals.

\begin{tabular}{lllll}
\hline & & $\begin{array}{l}\text { Sample Interval } \\
\text { Depth (m) }\end{array}$ & $\begin{array}{l}\text { Sample Interval } \\
\text { Elevation } \\
\text { (m.a.s.l.) }\end{array}$ & Polarity \\
\hline $88-28$ & Wample & $298.6-300.4$ & $1813.6-1815.4$ & Normal \\
$88-28$ & W1-2 & $874.8-877.6$ & $1236.2-1239.0$ & Reversed \\
$28-32$ & W2-1 & $1097.5-1098.2$ & $1110.5-1111.3$ & Normal \\
$28-32$ & W2-2 & $1048.9-1050.4$ & $1158.3-1159.8$ & Normal \\
$14-23$ & W3-1 & $792.0-792.6$ & $1205.2-1205.8$ & Normal \\
$14-23$ & W3-2 & $793.4-794.8$ & $1203.0-1204.4$ & Normal \\
$14-23$ & W3-3 & $816.3-818.1$ & $1179.7-1181.5$ & Normal \\
$87-13$ & W4-1 & $1566.5-1568.0$ & $477.6-479.1$ & Reversed \\
$87-13$ & W4-2 & $1132.3-1135.1$ & $910.6-913.4$ & Reversed \\
$62-21$ & W5-1 & $510.5-511.2$ & $1501.7-1502.3$ & Reversed \\
\hline
\end{tabular}

Selection criteria included well location as described previously (Fig. 2.1), length of continuous interval, and the number of shear fractures with good shear-sense indicators.

Van Alstine and Butterworth (2002) describe the paleomagnetic core orientation procedures applied to the Medicine Lake core samples. The best continuous core intervals were marked with an axial Master Orientation Line (MOL) on the circumference of the core. The axial center of the core and the MOL define a vertical plane with an azimuth in the direction of the MOL relative to which shear fractures can be measured. The position of the MOL on the circumference of the core was selected so that the resulting plane was parallel to the predominant fracture strike within each interval so that core plugs drilled parallel and antiparallel to the MOL-defined plane 
would intersect the fewest fractures (Fig. 2.2). This reduces the possibility that a core plug being drilled will intersect a fracture, thereby complicating the drilling process as circulation of drilling fluid is lost. A suite of $2.5 \mathrm{~cm}$ diameter paleomagnetic plugs, divided evenly between parallel and antiparallel to the MOL-defined plane, were then drilled and prepared for measurement of their natural remanent magnetization (NRM). The plugs were subjected to progressive thermal demagnetization at temperature steps between $115^{\circ}$ and $405^{\circ} \mathrm{C}$, the optimum temperature range based on previous work on the thermally similar Tiwi geothermal field in the Philippines. This allowed the presentaxial-dipole field (PADF) viscous remanent magnetization (VRM) to be determined. Using PADF VRM, a secondary magnetization component of the total NRM, for the reference direction is desirable because it does not require the precise age of the rocks, reference apparent polar wander path, or the structural attitude. Finally, the paleomagnetically oriented core plugs allow the MOL to be referenced to present-day geographic north for each continuous core segment.

After the oriented core samples were returned to EGI, they were placed in a fixture to hold them vertically (Fig. 2.3). The MOL was aligned with the orientation azimuth specified by Van Alstine $(2006,2007)$ using a Brunton compass. The core samples were thus held in a stable position and oriented with respect to present-day geographic north as though they were in situ while the fractures were measured. The dip direction and dip of all natural fractures, along with the trend and plunge of any slipstriae, were measured and recorded. Drilling-induced fractures and fractures of ambiguous origin were ignored. The shear-sense criteria described by Petit (1987) were used to determine the displacement sense of the fracture. Although the 


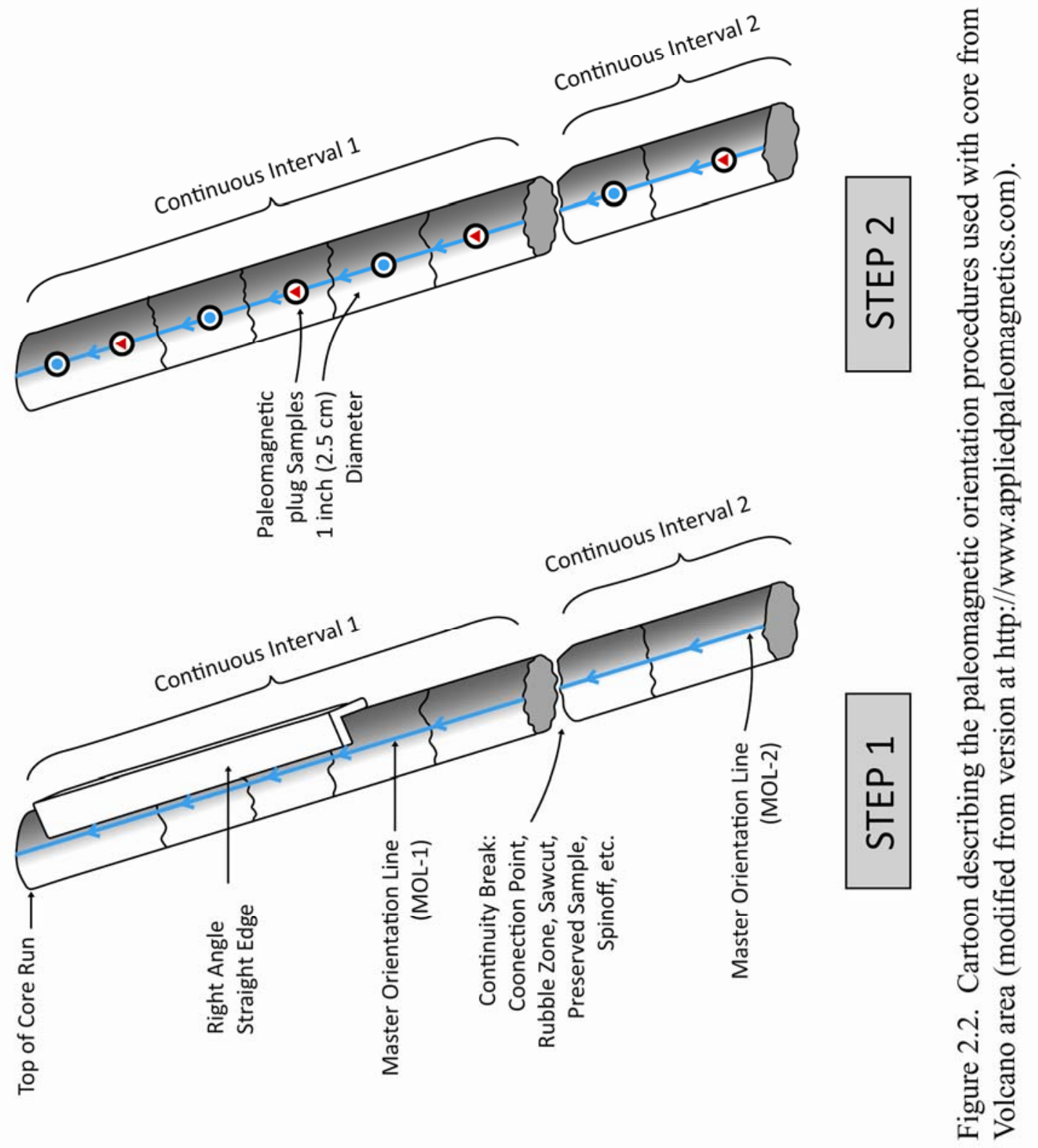




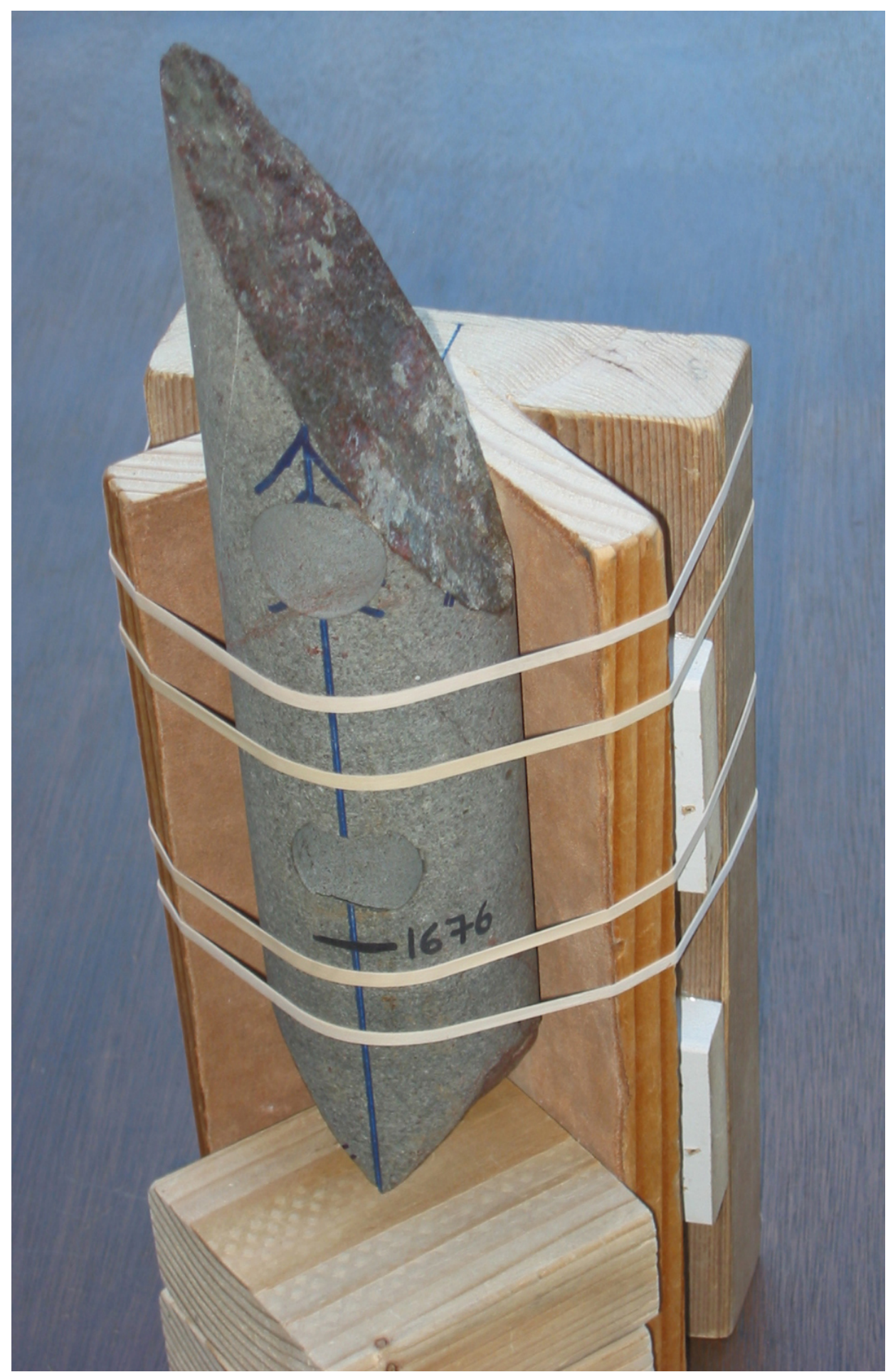

Figure 2.3. Photograph of $6.2 \mathrm{~cm}$ diameter oriented core segment from well 62-21 held in fixture for fracture and striation measurements. Note the two core plug holes from the paleomagnetic orientation process, the sample depth (in feet) and the blue MOL line. The upper core plug was drilled into the MOL and the lower core plug, exhibiting a rough irregular edge, was drilled from the opposite side. 
slip sense could not always be determined, the striae still provide information as to whether the shear was predominantly strike-slip or dip-slip. Confidence in the interpreted displacement sense was also recorded.

Rose diagrams and stereoplots of the shear fracture and striae orientations were constructed using SpheriStat (Pangaea Scientific, 1990, v2.2). Intervals W3-1 and W3-2 in ML 14-23 were nearly adjacent in depth and contained only four shear fractures each, so these intervals are represented by a single rose diagram and stereoplot. Some striae did not plot on the great circle representing the fracture plane. This situation occurred most often on moderate to steeply dipping planes. Because it is usually easier to measure the striation plunge more accurately than the trend on such planes, the assumption was made that the plunge is correct and the value for the trend in these cases was adjusted to place the striation point on the great circle. This was done by estimating a new trend using the existing stereoplots, changing the value for that striation in the SpheriStat spreadsheet file, and fine tuning the trend value as needed.

To better understand the faulting kinematics in and around MLV, the maximum contraction (P) and dilation (T) axes were plotted for each shear fracture. Additionally, determining the $\mathrm{P}$ and $\mathrm{T}$ axes provided a means to validate the slip sense of low confidence striae and to infer the slip sense of striae with an unknown sense by comparing them to the grouping of the axes of higher confidence striae. The $\mathrm{P}$ and $\mathrm{T}$ axes were plotted manually on a Schmidt stereonet. The trend and plunge for each axis point was then entered into SpheriStat. The SpheriStat program was also used to calculate the mean direction of extension and contraction for each well. The direction calculations are based on eigenvectors from a Bingham axial distribution. Such 
calculations were made for striae data separated into two categories, based on their slip sense, for each well. The first category uses only the highest confidence striae with an unambiguous slip sense. The second category adds striae with very low confidence unambiguous slip sense and the inferred slip sense, based on the overall pattern of $\mathrm{P}$ and $\mathrm{T}$ axes, of all striae with an ambiguous sense of slip.

\section{Field Work}

Outcrop measurements were made by Dr. Michal Nemčok at 20 locations over an area of approximately $1480 \mathrm{~km}^{2}$ encompassing Medicine Lake Volcano (Fig. 2.4). Orientation measurements of faults, fissures, joints, and shear fractures were recorded. Fracture measurements consisted of the dip direction and dip of the fracture plane and the trend and plunge of any visible striae. Shear sense and confidence levels were recorded using the same scheme described previously in the oriented core section. As with the fracture measurements in the oriented core, shear sense was not determinable in every case, but still provided an indicator on the type of slip. Finally, any other significant observations such as lithology, structure, and relationship to other locations were recorded. Photographs were taken as needed to help convey observations.

Rose diagrams and stereoplots of the field data were plotted as needed using SpheriStat in the same way they were created for the oriented core. The P and T axes were also plotted for Sites 14,15 , and 18, the only sites containing multiple fractures and striae with determinable slip sense. The $\mathrm{P}$ and $\mathrm{T}$ axes were plotted and processed using the methods described in the oriented core section. 


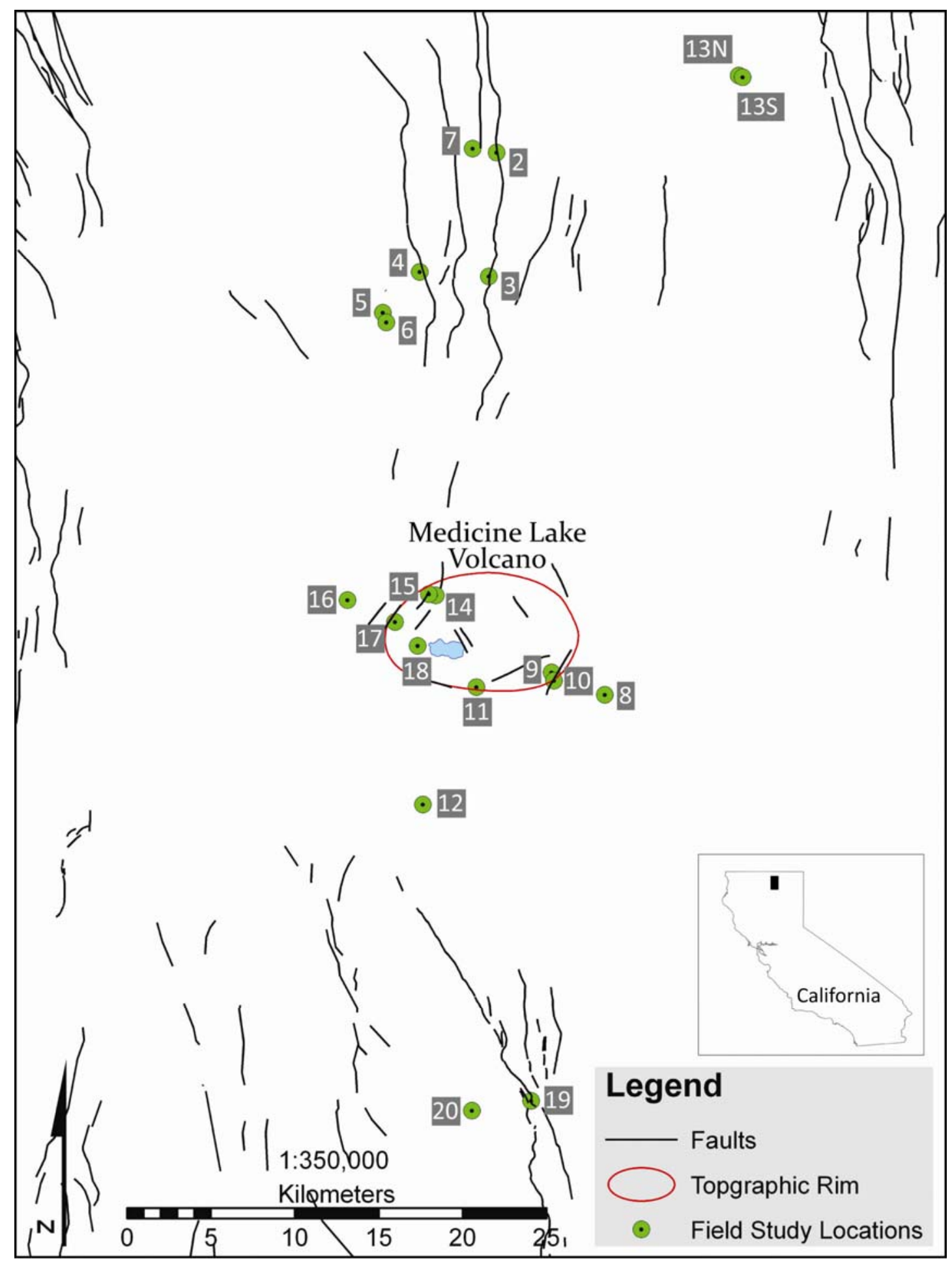

Figure 2.4. Fault map of the Medicine Lake Volcano area depicting the field sites that were studied by Dr. Michal Nemčok in 2006. Faults farther to the north and south of the topographic rim are from the USGS Quaternary Fault and Fold Database. Faults close to the topographic rim are from the Alturas sheet of the 1958 California Department of Natural Resources Geologic Map of California. 


\section{Magnetotelluric Mapping}

The magnetotelluric (MT) dataset from Cumming and Mackie (2007) was mapped for 11 selected elevation cuts ranging from -487 meters above sea level (masl) to 1912 masl to provide a subsurface framework to enable fault dips and directions around Medicine Lake Volcano to be inferred (Table 2.2). Each line of data consists of the resistivity value and the $\mathrm{X}, \mathrm{Y}$, and $\mathrm{Z}$ position values describing the location in threedimensional space. There are 42 increments of 400 meters in the " $X$ " direction denoted by UTM Northing coordinates, 58 increments of 400 meters kilometers in the "Y" direction denoted by UTM Easting coordinates, and 172 increments of 25 meters in the "Z" direction denoted by elevation in meters above sea level. Therefore, the database consists of 418,992 lines of data. Because the elevations of the blocks increase and decrease from the mean sea level zero point in 25 meter increments, the elevation of the centers of the blocks start at 12.5 meters above and below sea level. The elevation cuts shown in Table 2.2 are represented in this form, rounded to the nearest meter. The volume that these points occupy in space extends above and below the surface of the earth. Resistance values below the surface are about 0-250 Ohm-m, while those above the surface are essentially infinite. Therefore, the approximate topography is defined at elevation blocks that include data from above and below the earth's surface.

The elevation slices were selected to meet three key requirements. The first was to match the four elevation slices included in the Cumming and Mackie (2007) report, providing a quality check for the data processing. The second was to select a lowest boundary elevation that has been penetrated by the deepest wells to allow integration of 
Table 2.2

MT elevation slices.

\begin{tabular}{cc}
\hline Slice & Elevation (m.a.s.l.) \\
\hline 1 & 1912 \\
2 & $1712^{1}$ \\
3 & $1612^{1}$ \\
4 & 1312 \\
5 & $1012^{1}$ \\
6 & 712 \\
7 & 412 \\
8 & 112 \\
9 & $12^{1}$ \\
10 & -187 \\
11 & -487 \\
\hline${ }^{1}$ Slices approximately correspond \\
to maps published by Cumming \\
and Mackie (2007).
\end{tabular}

well-derived data with the MT data. The third was to provide a maximum elevation difference of 300 meters between maps to provide adequate resolution for correlation of mapped fault traces at the surface and the individual slices to infer fault orientations and dips at depth. The elevation difference between some maps is less than 300 meters because some of the quality control elevations fall between planned elevation slices. The dataset was imported into an Excel spreadsheet. Data from all but the elevations of interest were then excluded and the remaining 2436 lines of data for each of the 11 selected elevation slices were converted to dBase IV format and imported into ArcGIS. Several ArcGIS mapping algorithms were tested and compared to the maps published in the Cumming and Mackie (2007) report. The spline algorithm was found to provide the 
best match to the published maps and was adjusted to duplicate the color coding and resistivity ranges. The same procedure was then applied to the remaining elevation slices to produce eleven $16.8 \mathrm{~km} \times 23.2 \mathrm{~km}$ resistivity maps. Various other datasets such as fault traces (U. S. Geological Survey, 1971; Union, 1975), topographic and geologic map overlays (U. S. Geological Survey, 1988a, b, c; U. S. Geological Survey, 1993; State of California Department of Natural Resources, 1958), well locations, age data (DonnelyNolan and Lanphere, 2005; Van Alstine, 2006, 2007), field measurement locations and data (Nemčok, Energy and Geoscience Institute, unpublished data, 2006), and digital elevation models (DEM) (http://seamless.usgs.gov) were also added to the ArcGIS model so they could be used as needed to aid interpretation of the MT data.

The ArcGIS maps of the MT resistivity were also incorporated as images into the Petrel model after being sized with Adobe Photoshop so that all location data would match precisely. Sizing and location accuracy were checked by insuring that ArcGIS well locations on the MT maps precisely coincided with the well locations in the existing Petrel model, and that the corner coordinates of the MT maps were also correctly positioned at the corresponding coordinates in the Petrel model. Figure 2.5 depicts three of the MT resistivity maps $(-188,712$, and 1612 masl) and the well bores in the Petrel model to illustrate how the maps were used as a guide for inferring fault zone orientations at depth. The MT maps were also compared with other 3-D data sets in the Petrel model to infer sub-surface structures. 


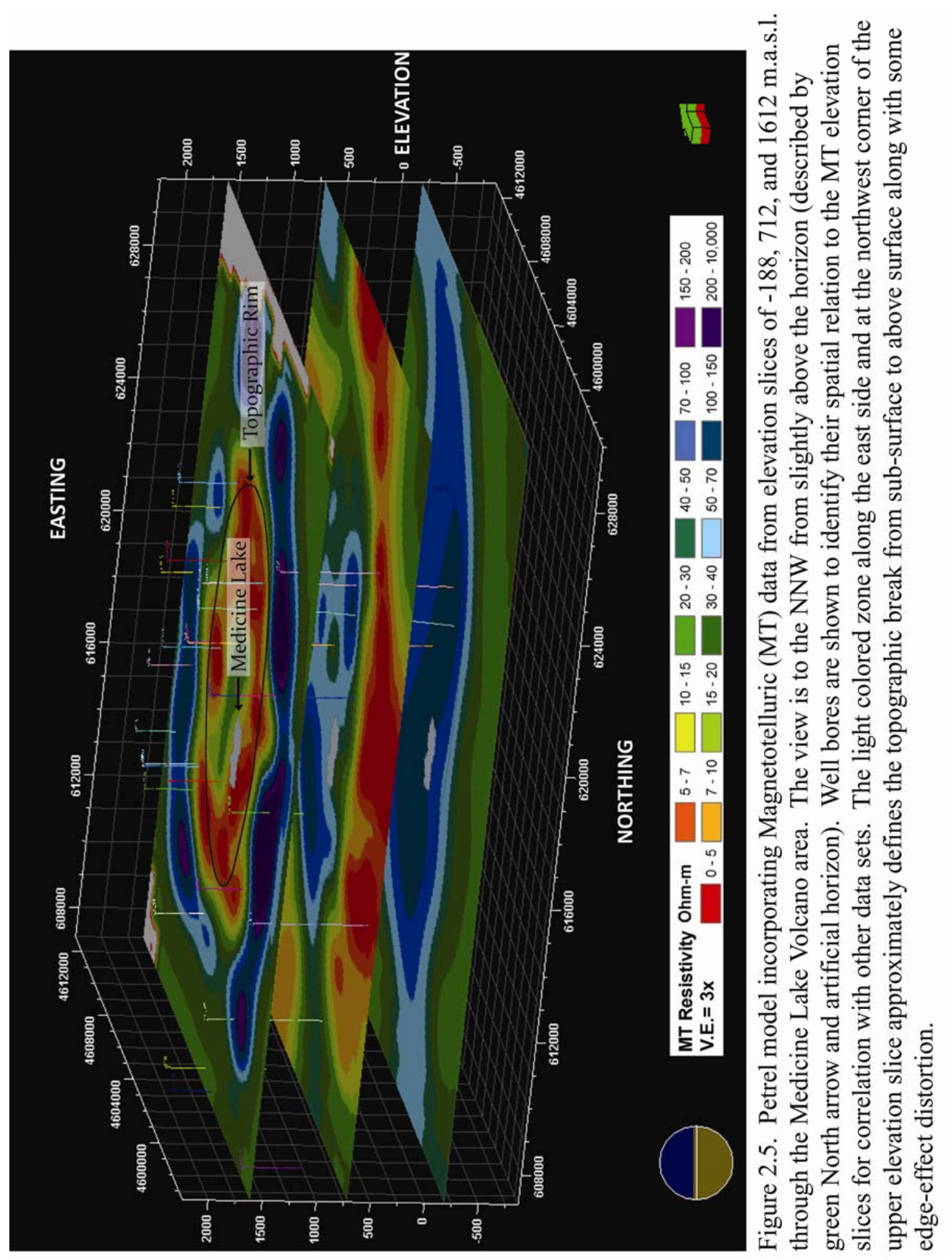




\section{Quaternary Fault and Fold Database}

The U.S. Geological Survey Quaternary Fault and Fold Database of the United States (http://earthquake.usgs.gov/regional/qfaults/) was used to establish regional faulting trends in the area around Medicine Lake Volcano based on fault locations and other fault parameters. The compiled data for the Quaternary faults found on the Alturas $1^{\circ} \times 2^{\circ}$ sheet that includes Medicine Lake, as well as the eight $1^{\circ} \times 2^{\circ}$ surrounding sheets, were examined and summarized for each sheet (Fig. 2.6). The sheets cover approximately 18,870 square kilometers between $40^{\circ}$ and $43^{\circ}$ North Latitude and $120^{\circ}$ and $124^{\circ}$ West Longitude. The Newberry ring faults from the Crescent $1^{\circ} \times 2^{\circ}$ sheet further north were also studied, bringing the total number of faults or fault zones in the studied area to 174 . Of these, no specific fault information, other than the mapped location, were available for 44 of the California faults because the database is incomplete. Some faults are completely absent from the database for the same reason (http://earthquake.usgs.gov/regional/qfaults/faq.php\#citation).

The compiled reports for all of the faults or fault zones contained in the area covered by the $1^{\circ} \times 2^{\circ}$ sheets were studied to determine the average strike and dip, displacement sense, location reliability, and any other relevant information.

\section{$\underline{\text { Temperature Surface Model }}$}

A three-dimensional temperature model of MLV was constructed using the Petrel program. The wellhead locations and well traces were first entered into the program and displayed in three-dimensional space. Then the depths corresponding to measured temperatures of $50^{\circ}, 100^{\circ}, 150^{\circ}, 200^{\circ}, 250^{\circ}$, and $275^{\circ} \mathrm{C}$ were entered for each well trace. 


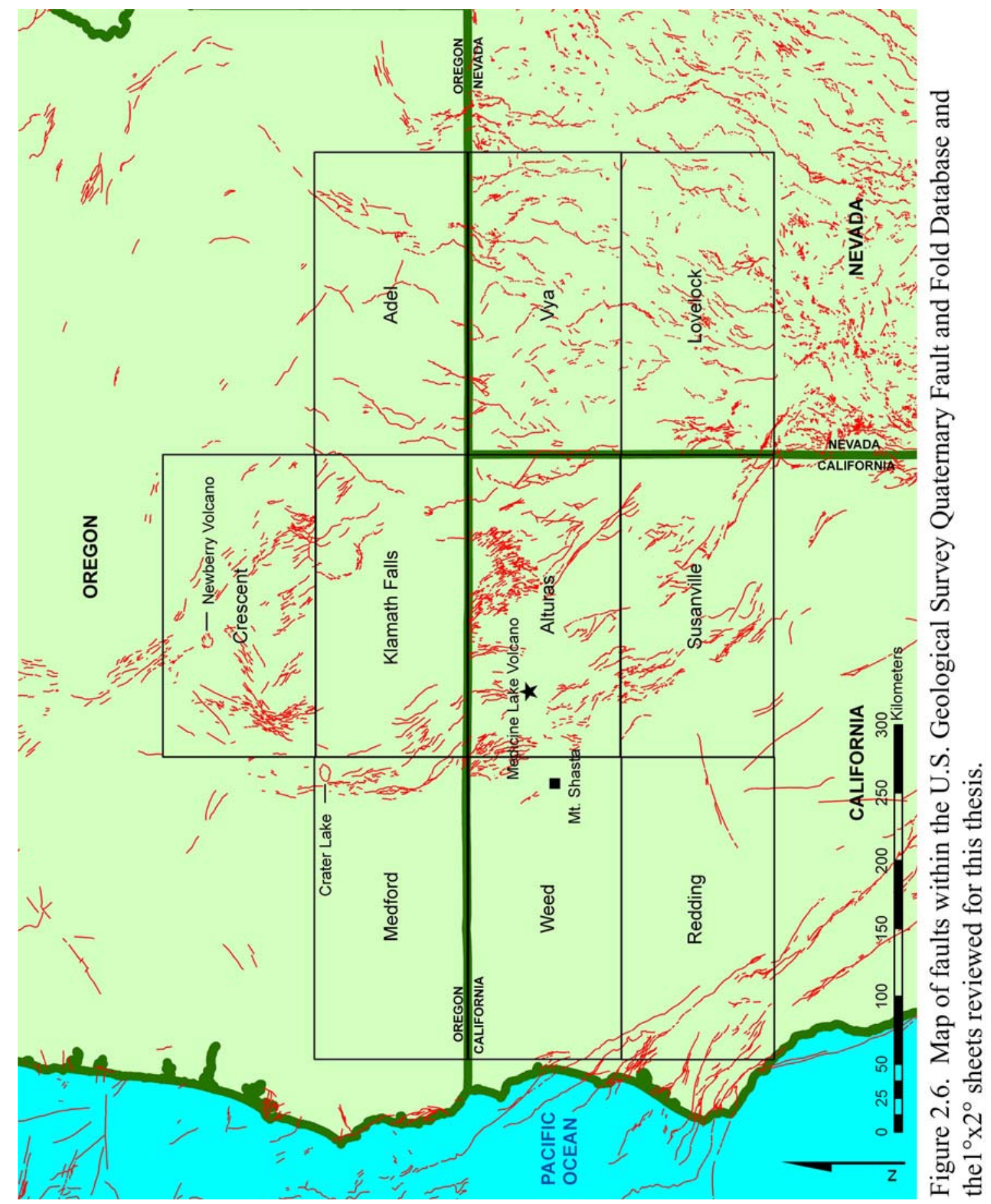


The temperature data were obtained from temperature surveys conducted in 17 wells (Table 2.3). The wells range in depth from 499 to 2678 meters, with eight exceeding 1000 meters. The data for 15 of the wells were taken from Temperature/Depth plots compiled by Carrier (1989b). Temperature data for GMF 88-28 (Jones, 1994) and GMF 31-17 (Stark, 2005) were taken directly from temperature-depth surveys. The temperature point data were then interpolated between the wells using the Convergent Interpolation algorithm in the Petrel software to generate three-dimensional surfaces for each of the six temperature values.

Thermal stability is usually attained within weeks for the shallow boreholes, but may take up to about six months for the deeper wells (Dr. Joseph Moore, Energy and Geoscience Institute, personal communication). While the time between well completion and the temperature surveys is not usually known for these wells, Carrier (1989b) compiled the most reliable data available. Therefore, it is assumed that most of the well data found in Carrier (1989b) are reasonably close to thermal equilibrium. An exception is GMF 68-8 which was noted to have not yet fully returned to undisturbed formation temperatures after being static for 33 days (Carrier, 1989b). GMF 88-28 was reported as static by Jones (1994) and is assumed to be at or near thermal equilibrium. The thermal stability of GMF 31-17 at the time of the 2002 survey (Stark, 2005) is not known. However, the comparison of several earlier temperature-depth plots (Carrier, 1989a; Carrier, 1989b; CalEnergy, 1998) suggests that the well was at or near thermal equilibrium. 
Table 2.3

Elevation of the shallowest occurrence of specific temperatures derived from downhole surveys in the Medicine Lake Volcano area.

\begin{tabular}{|c|c|c|c|c|c|c|c|c|}
\hline \multirow[b]{2}{*}{ Well } & \multirow[b]{2}{*}{$\mathrm{KB}$ (masl) } & \multirow[b]{2}{*}{$\mathrm{TD}(\mathrm{m})$} & \multicolumn{6}{|c|}{ Elevation of Indicated Temperature (m.a.s.1.) } \\
\hline & & & $50^{\circ} \mathrm{C}$ & $100^{\circ} \mathrm{C}$ & $150^{\circ} \mathrm{C}$ & $200^{\circ} \mathrm{C}$ & $250^{\circ} \mathrm{C}$ & $275^{\circ} \mathrm{C}$ \\
\hline $14-23$ & 1998 & 914 & 1236 & & & & & \\
\hline $17-6$ & 2062 & 1219 & 1413 & 1230 & 1185 & 1140 & 864 & \\
\hline $28-32$ & 2209 & 1372 & 1659 & 1394 & 1335 & 1210 & 990 & \\
\hline $29-1$ & 2029 & 939 & 1304 & & & & & \\
\hline $31-17$ & 2143 & 2678 & 1852 & 1762 & 1671 & 1555 & 1365 & \\
\hline $36-28$ & 2040 & 654 & 1491 & & & & & \\
\hline $44-33$ & 2120 & 690 & 1810 & 1738 & 1697 & 1663 & & \\
\hline $45-36$ & 2123 & 1219 & 1681 & 1544 & 1333 & & & \\
\hline $56-3$ & 2077 & 545 & 1544 & & & & & \\
\hline $57-13$ & 1876 & 915 & 994 & & & & & \\
\hline $62-21$ & 2013 & 653 & 1599 & 1526 & 1369 & & & \\
\hline $65-26$ & 1958 & 664 & 1374 & & & & & \\
\hline $68-8$ & 2138 & 2566 & & 1711 & 1650 & 1528 & 1132 & -15 \\
\hline $84-17$ & 2126 & 499 & 1785 & 1666 & & & & \\
\hline $86-23$ & 1858 & 1068 & 901 & & & & & \\
\hline $87-13$ & 2046 & 1809 & 1876 & 1849 & 1774 & & & \\
\hline $88-28$ & 2114 & 1347 & 1836 & 1697 & 1651 & 1298 & & \\
\hline
\end{tabular}

$\mathrm{KB}$ - Elevation $=$ Measured Depth 


\section{$\underline{\text { Alteration Mineral Surface Model }}$}

A three-dimensional mineral-alteration model was created in Petrel using methods similar to those described for the Temperature Model. This data was obtained from previously conducted X-Ray Diffraction studies by Dr. Jeffrey Hulen and Dr. Susan Lutz on 23 MLV wells (Table 2.4). The data were used to define the tops of hydrothermal mineral alteration zones for anhydrite, biotite, calcite, chlorite, epidote, illite, and smectite (Hulen, 1984, 1985a, 1985b; Lutz, 1988a, 1988b, 1990). Because the elevation for the first occurrence of calcite and chlorite from the X-Ray Diffraction data for GMF 17A-6 appeared unrealistically deep, data for these minerals was taken from Carrier (1989a).

\section{$\underline{\text { Faulting Theory Calculations }}$}

General faulting theory calculations were used to check whether fault dips inferred from other data sets are reasonable for their respective lithologies. Anderson's (1951) fault theory states that the angle of the normal to the fault plane $(\theta)$ relative to the maximum principal stress $\left(\sigma_{1}\right)$ varies with the angle of internal friction $(\varphi)$, a parameter specific to a given lithology (Fig. 2.7):

$$
\theta= \pm\left(45^{\circ}+\varphi / 2\right)
$$

In the case of normal faulting, where $\sigma_{1}$ is approximately vertical, the dip will be equal to $\theta$. Because the rock column between the surface and the lowest MT elevation slice consists of various volcanic rocks as well as some sedimentary horizons, the well logs from the eight completely logged wells were examined to determine the predominant 
Table 2.4

Elevation of the shallowest occurrence of specific mineral distributions derived from well cores in the Medicine Lake Volcano area.

\begin{tabular}{|c|c|c|c|c|c|c|c|c|c|}
\hline \multirow[b]{2}{*}{ Well } & \multirow[b]{2}{*}{ KB (masl) } & \multirow[b]{2}{*}{$\mathrm{TD}(\mathrm{m})$} & \multicolumn{7}{|c|}{ Elevation at Top of Indicated Mineral Surface (m.a.s.l.) } \\
\hline & & & Anhydrite & Biotite & Calcite & Chlorite & Epidote & Illite & Smectite \\
\hline $14-23$ & 1998 & 914 & & & & & & & 1552 \\
\hline $17 \mathrm{~A}-6$ & 2062 & 2932 & -17 & -17 & 1681 & 1086 & 654 & 861 & 1635 \\
\hline $18-34$ & 1791 & 1067 & & & 725 & & & 1613 & 1613 \\
\hline $27-27$ & 1773 & 914 & & & 998 & & & & 998 \\
\hline $28-32$ & 2209 & 1372 & 1453 & & 2075 & 1453 & 1132 & 1752 & 2075 \\
\hline $29-1$ & 2029 & 939 & & & & & & & 1634 \\
\hline $31-17$ & 2143 & 2678 & 1277 & 1159 & 1952 & 1643 & 1943 & & 2124 \\
\hline $36-28$ & 2040 & 654 & & & 1400 & & & & 1689 \\
\hline $44-33$ & 2120 & 690 & & & & & & & 2029 \\
\hline $45-36$ & 2123 & 1219 & 904 & & 1818 & 1395 & 1026 & 1556 & 1977 \\
\hline $52-4$ & 1721 & 1219 & & & 1121 & & & & 1121 \\
\hline $56-3$ & 2077 & 545 & & & 1642 & 1739 & & & 2014 \\
\hline $57-11$ & 1968 & 915 & & & & & & & 1725 \\
\hline $57-13$ & 1876 & 915 & & & 983 & & & 1242 & 1242 \\
\hline $62-21$ & 2013 & 653 & & & 1495 & & & & 1851 \\
\hline $65-26$ & 1958 & 664 & & & & & & 1394 & \\
\hline $68-16$ & 1956 & 896 & & & & & & 1390 & 1639 \\
\hline $68-8$ & 2138 & 2566 & & -400 & 1862 & 1576 & 1166 & 1568 & 2033 \\
\hline $75-6$ & 2047 & 609 & & & & & & & 1712 \\
\hline $84-17$ & 2126 & 499 & & & & & & & 1767 \\
\hline $86-23$ & 1858 & 1068 & & & & & & & 1646 \\
\hline $87-13$ & 2046 & 1809 & 1324 & & 1863 & & 1711 & & 1997 \\
\hline $88-28$ & 2114 & 1347 & 1077 & & 1901 & 1687 & 1196 & 878 & 1894 \\
\hline
\end{tabular}

KB - Elevation $=$ Measured Depth 


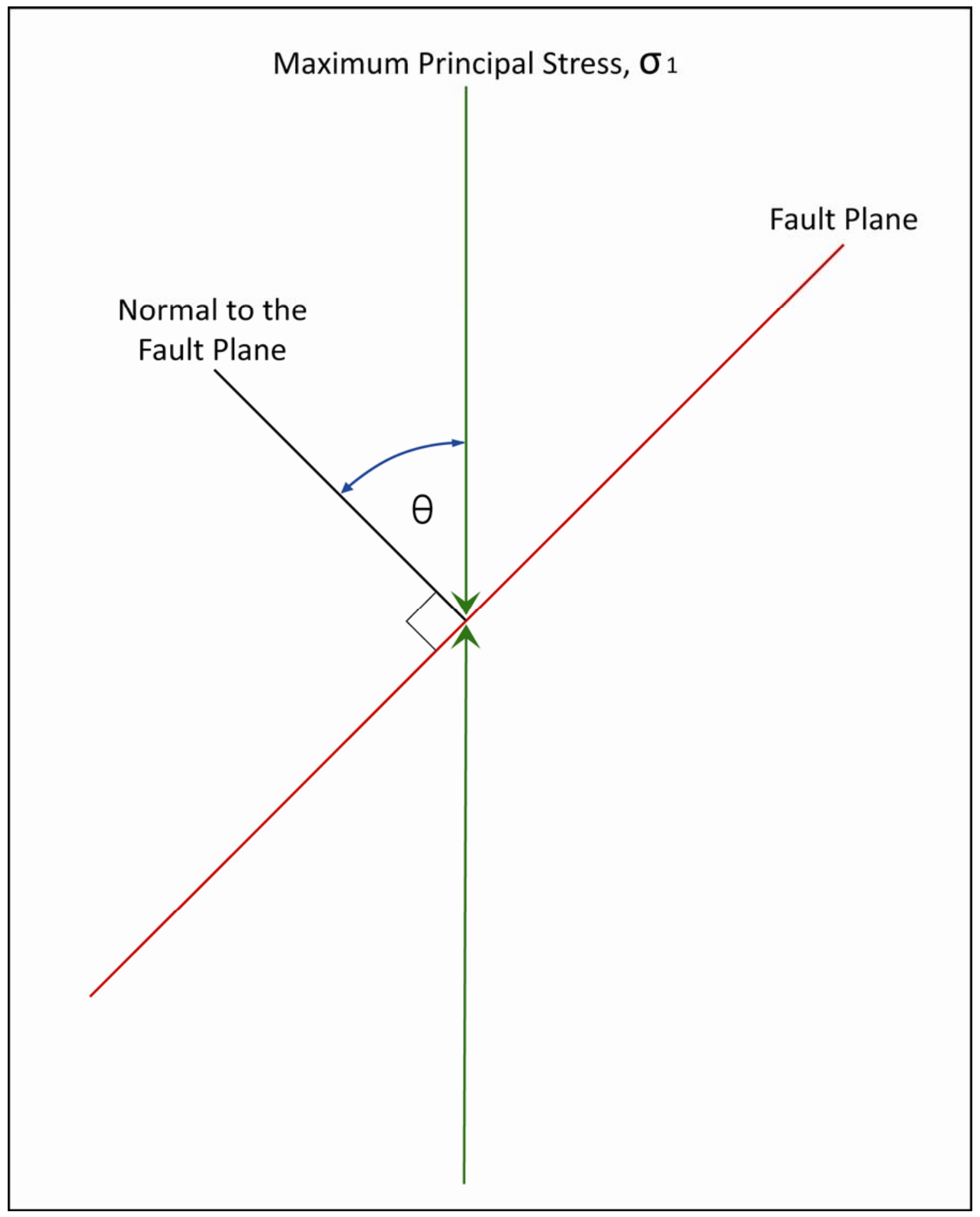

Figure 2.7. Diagram of the theoretical angle of a fault plane with respect to the maximum principal stress after Anderson (1951). 
rock types. The overall percentages of andesite, basalt, indeterminate andesite/basalt compositions, tuff/debris flows, and mixed felsic flows from these wells were then calculated to develop a general composite rock column for the Medicine Lake Volcano area. Values for the angle of internal friction were taken from Tables 7.1 and 7.2 of Toulokian et al. (1981). These tables do not include data for rhyolite. However, a friction angle for rhyolite was found in Konietzky (2004) that falls within the dacite friction angle range specified by Toulokian et al. (1981). Therefore, the mixed felsic flows category was treated as dacite. The theoretical range of dip angles was then computed. 


\section{CHAPTER 3}

\section{DATA}

\section{$\underline{\text { Introduction }}$}

This thesis integrates information of various types obtained from a wide range of sources. Some of the information is actual observations including core logs, fractures and striae in paleomagnetically oriented core, field measurements and observations, and fault data derived from geologic maps and the USGS Quaternary Fault and Fold Database. The magnetotelluric maps are not true data because some processing and interpretation of the original data have previously occurred. The temperature and mineral alteration sections report a combination of data and interpretation in the form of the interpolated Petrel surface models. Similarly, faulting theory calculations use true stratigraphic data combined with theoretical principles and assumed friction coefficients. This information forms the basis for the interpretation of structural features at Medicine Lake Volcano.

\section{$\underline{\text { Logged Core Fractures }}$}

About 26\% of the 1374 fractures examined in the logged core (Fig. 2.1, Table 3.1) contain discernable slip striae. The type of slip (dip, strike, or oblique) was recorded in unoriented cores in all coreholes/wells except for ML-86-23. The sense of slip was not, or could not, be determined for any of the striae. 
Table 3.1

Fracture and striation data obtained from unoriented core samples in the Medicine Lake Volcano area.

\begin{tabular}{cccccccc}
\hline & \multicolumn{3}{c}{$\begin{array}{c}\text { Number of Observed Fractures by } \\
\text { Slip Type }\end{array}$} & \multicolumn{2}{c}{$\begin{array}{c}\text { Fracture Dip Data } \\
\text { (Deg.) }\end{array}$} \\
Wel1/TGH & $\begin{array}{c}\text { Depth } \\
\text { (m) }\end{array}$ & Dip & Oblique & Strike & Unknown & Average & Range \\
\hline ML 14-23 & 914 & 19 & 14 & 5 & 39 & 48 & $5-85$ \\
GMF 88-28 & 1346 & 18 & 21 & 12 & 52 & 49 & $0-88$ \\
GMF 45-36 & 1219 & 55 & 23 & 6 & 494 & 44 & $3-85$ \\
GMF 28-32 & 1372 & 26 & 8 & 2 & 64 & 51 & $5-89$ \\
GMF 56-3 & 545 & 2 & 2 & 1 & 3 & 49 & $36-86$ \\
GMF 87-13 & 1809 & 44 & 27 & 7 & 0 & 60 & $5-89$ \\
ML 62-21 & 653 & 14 & 27 & 8 & 263 & 55 & $3-87$ \\
ML 18-34 & 1067 & 7 & 8 & 1 & 24 & 59 & $24-85$ \\
ML 86-23 & 1068 & & & & 78 & & \\
\hline
\end{tabular}

${ }^{1}$ No striae were recorded below $928 \mathrm{~m}$, although some may be present.

${ }^{2}$ Core was not recovered between $280 \mathrm{~m}$ and $960 \mathrm{~m}$ depth.

${ }^{3}$ Only the upper 350 meters were logged. No striae were recorded, although some may be present

Strike-slip and oblique-slip striae are more common in wells outside of the topographic ring than in wells within the ring (Fig. 3.1). Strike-slip or oblique-slip striae are between $50 \%$ and $71 \%$ of striae found within the exterior wells. In contrast, only $27-44 \%$ of striae in three interior wells indicate strike slip or oblique slip. The remaining interior well, GMF 56-3, is shallow and intersects only five striated fractures, three of which record strike slip or oblique slip. This result is therefore anomalous, but it is not robust. 


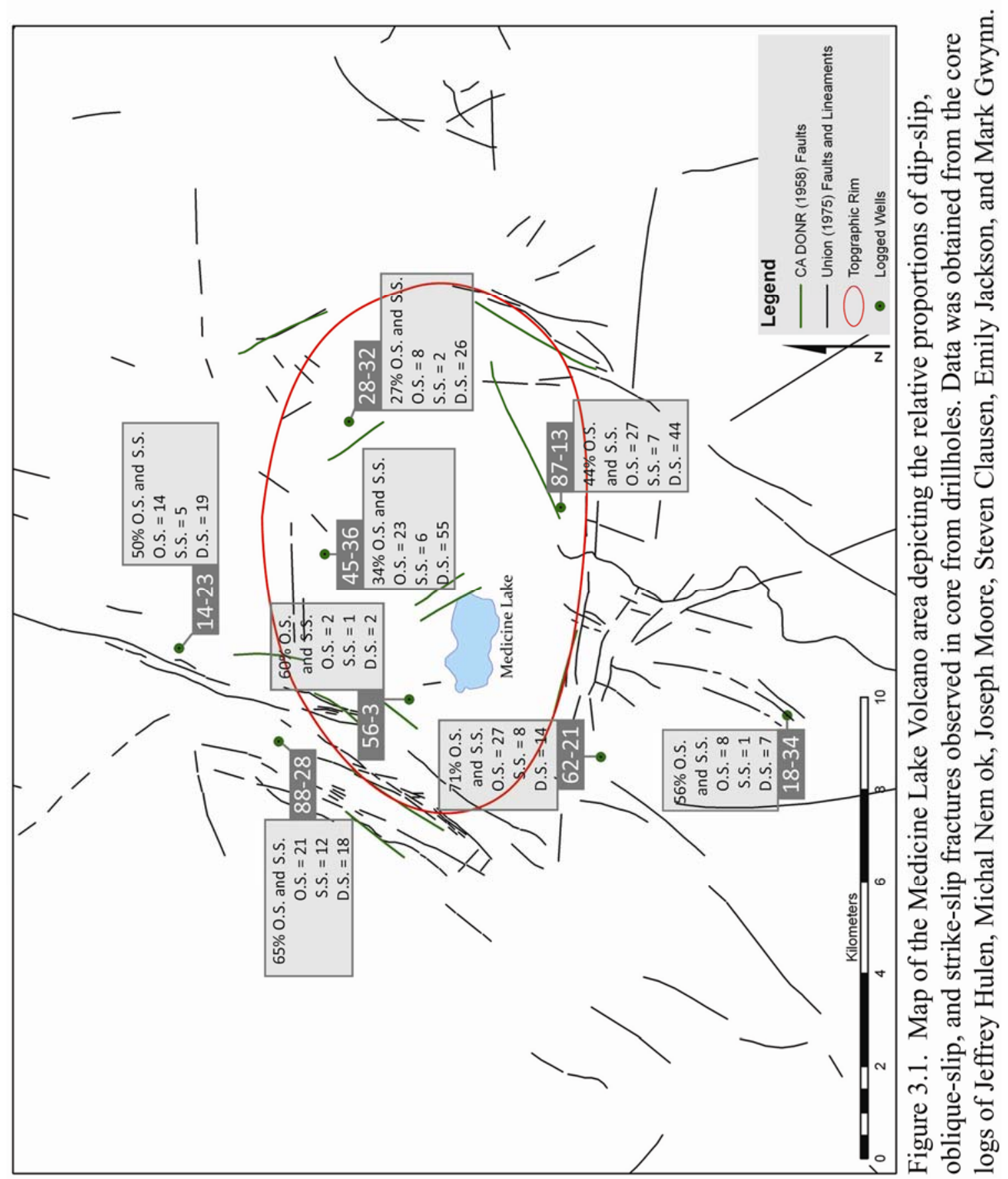


The distribution of each slip type does not vary with depth in GMF 28-32, GMF 87-13, and ML 62-21. In contrast, strike-slip movement tends to be more common at shallower depths in ML 14-23 (<790m), GMF 88-28 (<665m), and GMF 45-36 $(<500 \mathrm{~m})$. Dip slip in these wells predominates at greater depth. No meaningful observation of sliptype distribution can be made for GMF 56-3 (shallow depth and only five striated fractures) and ML 18-34 (most striated fractures observed in a 30 meter interval at about 1000 meters depth).

All of the wells show a broad range of fracture dips, but there are zones in ML 1423, ML 18-34, GMF 28-32, GMF 56-3, and GMF 87-13 (Fig. 3.2) where there are clusters of fractures that dip in the range of $50-70^{\circ}$.

\section{Fractures in Paleomagnetically Oriented Core}

The paleomagnetically oriented core samples from GMF 88-28, GMF 28-32, ML 14-23, GMF 87-13, and ML 62-21 yielded a dataset of 94 natural shear fractures (Fig. 2.1). Fifty-four of the fractures contain slip striae (Table 3.2a-e). All but three of the 54 fractures contain striae in a single orientation, representing monophase fractures. The remaining three fractures are polyphase; two of these fractures exhibit two generations of striae while the third contains three generations.

Stereoplots (Fig. 3.3) show orientations of shear fractures, striae, and slip senses in the oriented core samples. Plots of calculated P and T axes (Fig. 3.4) suggest the slip senses of four sets of striae that had been originally classified as "unknown" based on grouping of the $\mathrm{P}$ and $\mathrm{T}$ axes. Similarly, confidence in the slip sense for seven sets of striae with questionable slip senses was increased. The pattern of the $\mathrm{P}$ and $\mathrm{T}$ axes infer that the sense of three additional striae sets with questionable slip senses could be 
opposite to the observed sense and that two additional striae sets may also have a sense opposite to the observed sense. However, the observed senses of all unambiguous striae 

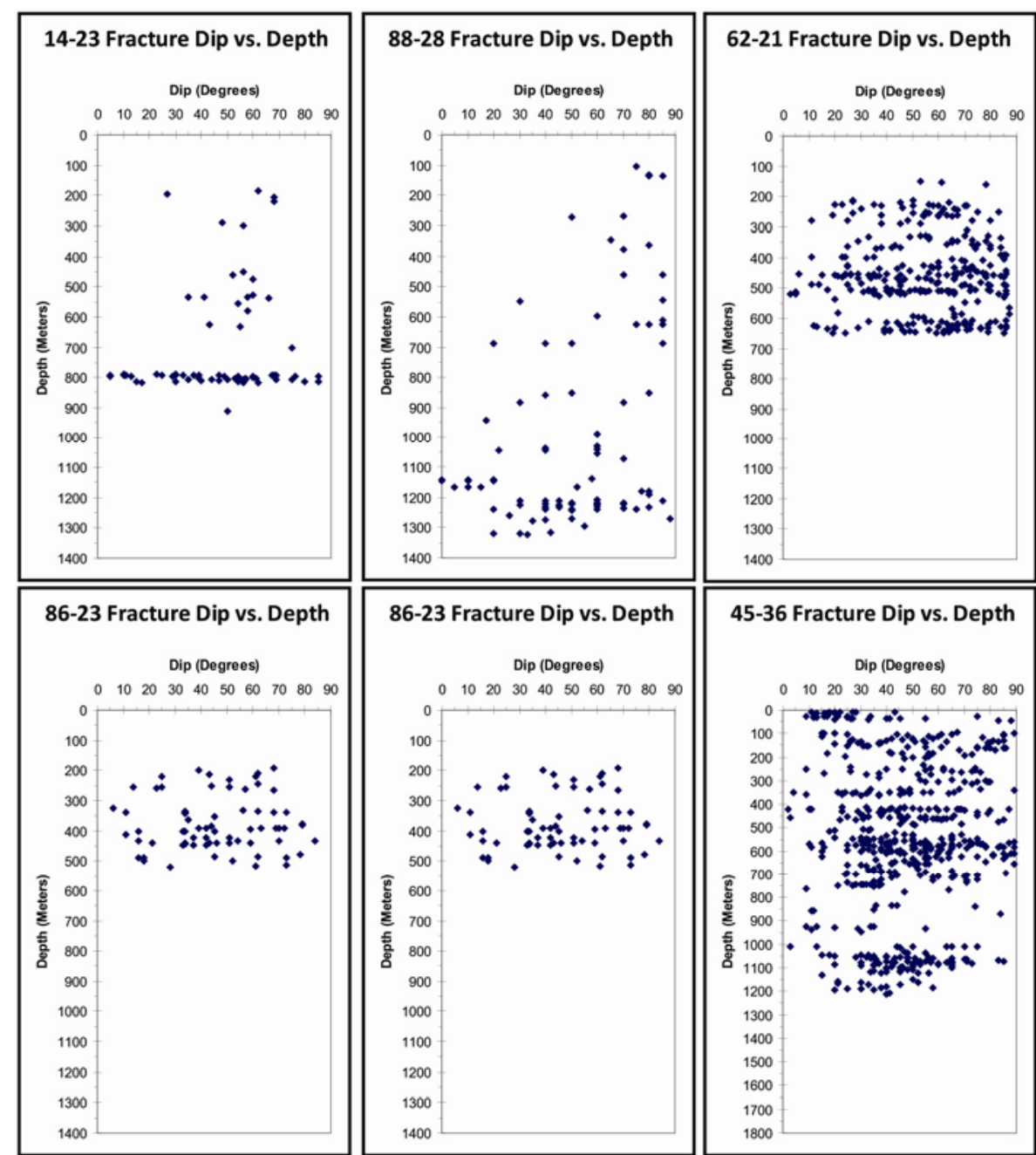

45-36 Fracture Dip vs. Depth
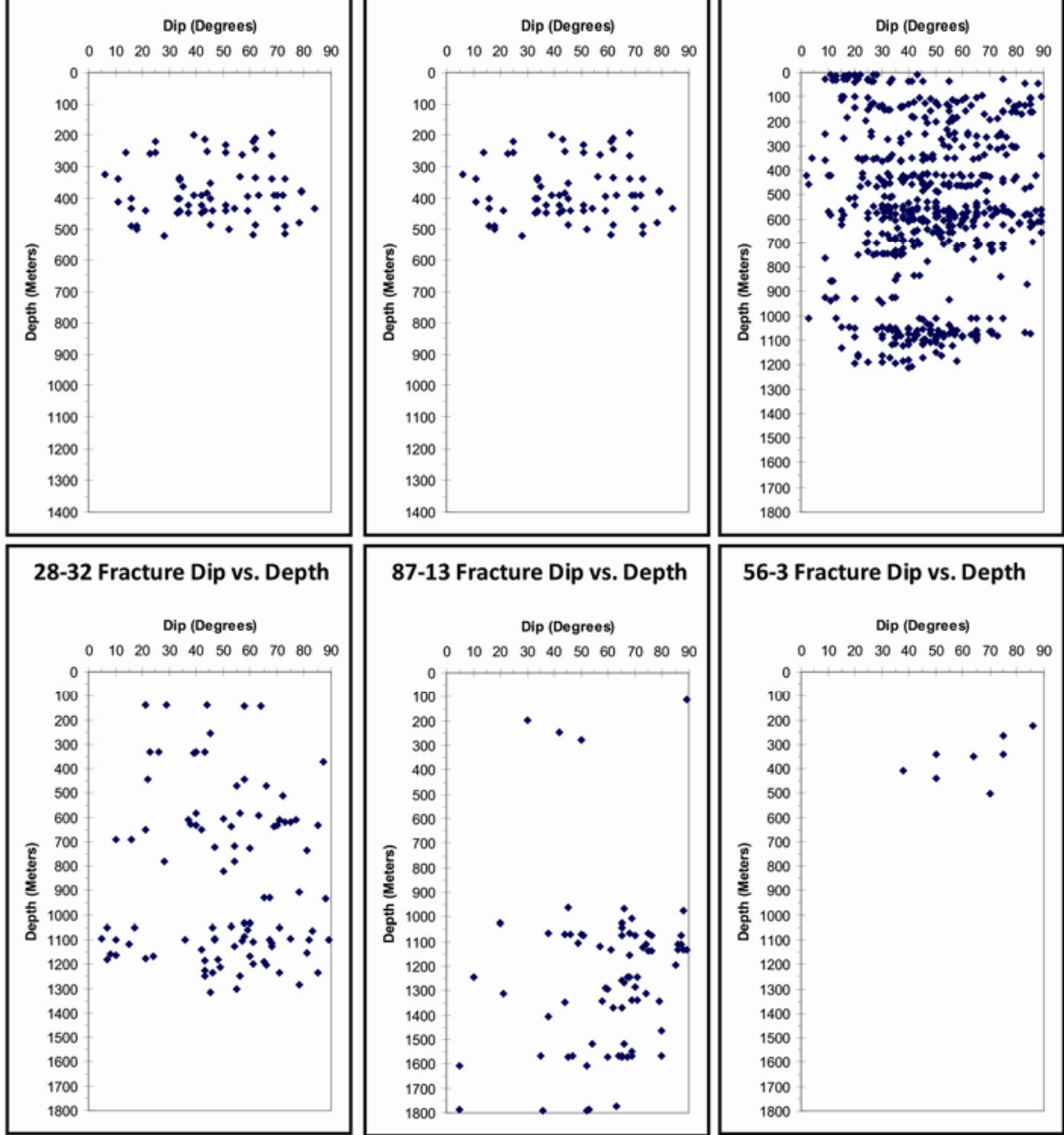

Figure 3.2. Distribution and quantity of fracture dips at indicated depths obtained from core logging of nine Medicine Lake Volcano wells. Data were obtained from the core logs of Jeffrey Hulen, Michal Nemčok, Joseph Moore, Steven Clausen, Emily Jackson, and Mark Gwynn. 
Table 3.2a

Depth, orientation, and slip sense of fractures exhibiting striae in paleomagnetically oriented core samples W1-1 and W1-2 from the Medicine Lake Volcano area.

\begin{tabular}{|c|c|c|c|c|c|c|c|c|}
\hline \multirow[b]{2}{*}{ Sample } & \multirow[b]{2}{*}{$\begin{array}{l}\text { Striae } \\
\text { Designator }\end{array}$} & \multirow[b]{2}{*}{$\begin{array}{l}\text { Depth } \\
\text { (m) }\end{array}$} & \multicolumn{2}{|c|}{ Fracture } & \multicolumn{2}{|r|}{ Striation } & \multirow[b]{2}{*}{$\begin{array}{l}\text { Observed } \\
\text { Sense }\end{array}$} & \multirow[b]{2}{*}{$\begin{array}{l}\text { P-T Inferred } \\
\text { Sense }\end{array}$} \\
\hline & & & $\begin{array}{l}\text { Dip } \\
\text { Azimuth } \\
\text { (Deg.) }\end{array}$ & Dip (Deg.) & $\begin{array}{l}\text { Trend } \\
(\text { Deg. })^{1}\end{array}$ & $\begin{array}{l}\text { Plunge } \\
\text { (Deg.) }\end{array}$ & & \\
\hline \multicolumn{9}{|c|}{ GMF 88-28 } \\
\hline W1-1 & $\mathrm{a}$ & 299.1 & 034 & 57 & 317 & 20 & Dextral & Sinistral \\
\hline W1-1 & $\mathrm{b}$ & 299.3 & 170 & 20 & 199 & 18 & Normal & Normal \\
\hline W1-1 & $\mathrm{c}$ & 300.4 & 229 & 5 & 217 & 5 & Normal & Normal \\
\hline W1-2 & $\mathrm{a}$ & 874.9 & 060 & 49 & 101 & 41 & Normal & Normal \\
\hline W1-2 & $\mathrm{b}$ & 874.9 & 030 & 38 & 045 & 37 & Normal & Normal \\
\hline W1-2 & c & 875.5 & 050 & 76 & 124 & 48 & Dextral & Dextral \\
\hline W1-2 & $\mathrm{d}$ & 875.6 & 109 & 59 & 102 & 59 & Normal & Normal \\
\hline W1-2 & e & 876.2 & 102 & 59 & 054 & 48 & Sinistral & Sinistral \\
\hline
\end{tabular}

${ }^{1}$ Some values have been adjusted slightly from original measurements to align striae with their great circle when plotted. 
Table $3.2 b$

Depth, orientation, and slip sense of fractures exhibiting striae in paleomagnetically oriented core samples W2-1 and W2-1 from the Medicine Lake Volcano area.

\begin{tabular}{|c|c|c|c|c|c|c|c|c|}
\hline \multirow[b]{2}{*}{ Sample } & \multirow[b]{2}{*}{$\begin{array}{l}\text { Striae } \\
\text { Designator }\end{array}$} & \multirow[b]{2}{*}{$\begin{array}{l}\text { Depth } \\
\text { (m) }\end{array}$} & \multicolumn{2}{|c|}{ Fracture } & \multicolumn{2}{|r|}{ Striation } & \multirow[b]{2}{*}{$\begin{array}{l}\text { Observed } \\
\text { Sense }\end{array}$} & \multirow[b]{2}{*}{$\begin{array}{l}\text { P-T Inferred } \\
\text { Sense }\end{array}$} \\
\hline & & & $\begin{array}{l}\text { Dip } \\
\text { Azimuth } \\
\text { (Deg.) }\end{array}$ & Dip (Deg.) & $\begin{array}{l}\text { Trend } \\
\text { (Deg.) })^{1}\end{array}$ & $\begin{array}{l}\text { Plunge } \\
\text { (Deg.) }\end{array}$ & & \\
\hline \multicolumn{9}{|c|}{ GMF 28-32 } \\
\hline W2-1 & $\mathrm{a}$ & 1097.5 & 135 & 18 & 203 & 7 & Unknown & Sinstral \\
\hline W2-1 & $\mathrm{b}$ & 1097.5 & 250 & 56 & 333 & 10 & Dextral & Dextral \\
\hline W2-1 & $\mathrm{c}$ & 1097.5 & 257 & 62 & 335 & 22 & Dextral & Dextral \\
\hline W2-1 & $\mathrm{d}$ & 1097.6 & 230 & 79 & 317 & 18 & Dextral & Dextral \\
\hline W2-1 & e & 1097.6 & 250 & 28 & 331 & 5 & Dextral & Dextral \\
\hline W2-1 & $\mathrm{f}$ & 1097.7 & 247 & 38 & 299 & 26 & Dextral & Dextral \\
\hline W2-1 & g & 1097.8 & 323 & 87 & 052 & 20 & Dextral? & Sinstral \\
\hline W2-1 & $\mathrm{h}$ & 1098.1 & 240 & 51 & 151 & 2 & Dextral & Dextral \\
\hline W2-2 & $\mathrm{a}$ & 1049.1 & 004 & 50 & 080 & 16 & Unknown & Normal \\
\hline W2-2 & $\mathrm{b}$ & 1050.0 & 047 & 21 & 093 & 15 & Normal & Normal \\
\hline W2-2 & $\mathrm{c}$ & 1050.1 & 010 & 57 & 086 & 23 & Normal & Normal \\
\hline W2-2 & $\mathrm{d}$ & 1050.2 & 014 & 25 & 052 & 20 & Normal & Normal \\
\hline W2-2 & $\mathrm{e}$ & 1050.3 & 017 & 32 & 049 & 28 & Normal & Normal \\
\hline
\end{tabular}

${ }^{1}$ Some values have been adjusted slightly from original measurements to align striae with their great circle when plotted. 
Table 3.2c

Depth, orientation, and slip sense of fractures exhibiting striae in paleomagnetically oriented core samples W3-1, W3-

2, and W3-3 from the Medicine Lake Volcano area.

\begin{tabular}{|c|c|c|c|c|c|c|c|c|}
\hline \multirow[b]{2}{*}{ Sample } & \multicolumn{5}{|c|}{ Fracture } & \multicolumn{3}{|l|}{ Striation } \\
\hline & $\begin{array}{l}\text { Striae } \\
\text { Designator }\end{array}$ & $\begin{array}{l}\text { Depth } \\
\text { (m) }\end{array}$ & $\begin{array}{l}\text { Dip } \\
\text { Azimuth } \\
\text { (Deg.) }\end{array}$ & Dip (Deg.) & $\begin{array}{l}\text { Trend } \\
(\text { Deg. })^{1}\end{array}$ & $\begin{array}{l}\text { Plunge } \\
\text { (Deg.) }\end{array}$ & $\begin{array}{l}\text { Observed } \\
\text { Sense }\end{array}$ & $\begin{array}{l}\text { P-T Inferred } \\
\text { Sense }\end{array}$ \\
\hline \multicolumn{9}{|c|}{ ML 14-23 } \\
\hline W3-1 & $\mathrm{a}$ & 792.1 & 345 & 30 & 017 & 26 & Dextral & Dextral \\
\hline W3-1 & $\mathrm{b}$ & 792.3 & 028 & 48 & 306 & 9 & Dextral & Dextral \\
\hline W3-1 & $\mathrm{c}$ & 792.3 & 253 & 19 & 213 & 15 & Unknown & Normal \\
\hline W3-1 & $\mathrm{d}$ & 792.7 & 310 & 17 & 269 & 13 & Unknown & Normal \\
\hline W3-2 & $\mathrm{a}$ & 793.5 & 134 & 27 & 076 & 15 & Normal & Normal \\
\hline W3-2 & $\mathrm{b}$ & 794.4 & 272 & 13 & 217 & 8 & Normal? & Normal \\
\hline W3-2 & $\mathrm{c}$ & 794.5 & 342 & 68 & 336 & 68 & Normal & Normal \\
\hline W3-2 & $\mathrm{d}$ & 794.5 & 012 & 63 & 331 & 56 & Normal & Normal \\
\hline W3-3 & $\mathrm{a}$ & 816.6 & 249 & 77 & 182 & 59 & Normal & Normal \\
\hline W3-3 & $\mathrm{b}$ & 816.8 & 266 & 68 & 331 & 46 & Normal? & Normal \\
\hline W3-3 & $\mathrm{c}$ & 816.9 & 116 & 17 & 158 & 13 & Dextral & Dextral \\
\hline W3-3 & $\mathrm{d}$ & 817.0 & 165 & 71 & 198 & 68 & Normal? & Normal \\
\hline W3-3 & e & 817.0 & 249 & 61 & 181 & 34 & Dextral? & Sinistral \\
\hline W3-3 & $\mathrm{f}$ & 817.2 & 071 & 73 & 136 & 54 & Normal & Normal \\
\hline W3-3 & $\mathrm{g}$ & 817.2 & 071 & 73 & 344 & 9 & Dextral? & Dextral \\
\hline
\end{tabular}

${ }^{1}$ Some values have been adjusted slightly from original measurements to align striae with their great circle when plotted. 
Table $3.2 \mathrm{~d}$

Depth, orientation, and slip sense of fractures exhibiting striae in paleomagnetically oriented core samples W4-1 and W4-2 from the Medicine Lake Volcano area.

\begin{tabular}{|c|c|c|c|c|c|c|c|c|}
\hline \multirow[b]{2}{*}{ Sample } & \multirow[b]{2}{*}{$\begin{array}{l}\text { Striae } \\
\text { Designator }\end{array}$} & \multirow[b]{2}{*}{$\begin{array}{l}\text { Depth } \\
\text { (m) }\end{array}$} & \multicolumn{2}{|c|}{ Fracture } & \multicolumn{2}{|r|}{ Striation } & \multirow[b]{2}{*}{$\begin{array}{l}\text { Observed } \\
\text { Sense }\end{array}$} & \multirow[b]{2}{*}{$\begin{array}{l}\text { P-T Inferred } \\
\text { Sense }\end{array}$} \\
\hline & & & $\begin{array}{l}\text { Dip } \\
\text { Azimuth } \\
\text { (Deg.) }\end{array}$ & Dip (Deg.) & $\begin{array}{l}\text { Trend } \\
(\text { Deg. })^{1}\end{array}$ & $\begin{array}{l}\text { Plunge } \\
\text { (Deg.) }\end{array}$ & & \\
\hline \multicolumn{9}{|c|}{ GMF 87-13 } \\
\hline W4-1 & $\mathrm{a}$ & 1566.6 & 067 & 47 & 028 & 40 & Reverse & Reverse \\
\hline W4-1 & $\mathrm{b}$ & 1566.7 & 127 & 53 & 163 & 47 & Reverse & Reverse \\
\hline W4-1 & $\mathrm{c}$ & 1567.1 & 351 & 57 & 356 & 57 & Reverse & Reverse \\
\hline W4-1 & $\mathrm{d}$ & 1567.2 & 070 & 39 & 078 & 35 & Reverse & Reverse \\
\hline W4-1 & e & 1567.3 & 042 & 43 & 047 & 43 & Reverse & Reverse \\
\hline W4-1 & $f$ & 1567.5 & 244 & 82 & 220 & 81 & Reverse? & Reverse \\
\hline W4-1 & g & 1567.6 & 310 & 56 & 262 & 45 & Reverse & Reverse \\
\hline W4-1 & $\mathrm{h}$ & 1568.0 & 061 & 65 & 061 & 65 & Reverse & Reverse \\
\hline W4-2 & $\mathrm{a}$ & 1132.9 & 225 & 70 & 267 & 64 & Normal & Normal \\
\hline W4-2 & $\mathrm{b}$ & 1133.6 & 274 & 75 & 355 & 31 & Sinistral? & Sinistral \\
\hline W4-2 & $\mathrm{c}$ & 1134.0 & 108 & 83 & 178 & 70 & Dextral & Dextral \\
\hline W4-2 & d & 1134.3 & 137 & 83 & 223 & 31 & Normal & Normal \\
\hline W4-2 & e & 1134.3 & 137 & 83 & 227 & 0 & Dextral & Dextral \\
\hline W4-2 & $f$ & 1134.6 & 316 & 87 & 233 & 64 & Normal & Normal \\
\hline W4-2 & $\mathrm{g}$ & 1135.1 & 312 & 86 & 230 & 64 & Normal & Normal \\
\hline
\end{tabular}

${ }^{1}$ Some values have been adjusted slightly from original measurements to align striae with their great circle when plotted. 
Table 3.2e

Depth, orientation, and slip sense of fractures exhibiting striae in paleomagnetically oriented core sample W5-1 from the Medicine Lake Volcano area.

\begin{tabular}{|c|c|c|c|c|c|c|c|c|}
\hline \multirow[b]{2}{*}{ Sample } & \multirow[b]{2}{*}{$\begin{array}{l}\text { Striae } \\
\text { Designator }\end{array}$} & \multirow[b]{2}{*}{$\begin{array}{l}\text { Depth } \\
\text { (m) }\end{array}$} & \multicolumn{2}{|c|}{ Fracture } & \multicolumn{2}{|r|}{ Striation } & \multirow[b]{2}{*}{$\begin{array}{l}\text { Observed } \\
\text { Sense }\end{array}$} & \multirow[b]{2}{*}{$\begin{array}{l}\text { P-T Inferred } \\
\text { Sense }\end{array}$} \\
\hline & & & $\begin{array}{l}\text { Dip } \\
\text { Azimuth } \\
\text { (Deg.) }\end{array}$ & Dip (Deg.) & $\begin{array}{l}\text { Trend } \\
(\text { Deg. })^{1}\end{array}$ & $\begin{array}{l}\text { Plunge } \\
\text { (Deg.) }\end{array}$ & & \\
\hline \multicolumn{9}{|c|}{ ML 62-21 } \\
\hline W5-1 & $\mathrm{a}$ & 510.6 & 276 & 59 & 216 & 40 & Normal? & Normal \\
\hline W5-1 & $\mathrm{b}$ & 510.6 & 286 & 76 & 014 & 8 & Sinistral & Dextral \\
\hline W5-1 & $\mathrm{c}$ & 510.7 & 282 & 65 & 008 & 9 & Sinistral? & Dextral \\
\hline W5-1 & $\mathrm{d}$ & 510.9 & 278 & 57 & 351 & 25 & Dextral & Dextral \\
\hline W5-1 & $\mathrm{e}$ & 510.9 & 278 & 57 & 287 & 57 & Normal & Normal \\
\hline W5-1 & $\mathrm{f}$ & 510.9 & 278 & 57 & 317 & 50 & Normal & Normal \\
\hline W5-1 & $\mathrm{g}$ & 511.1 & 272 & 63 & 358 & 8 & Dextral & Dextral \\
\hline
\end{tabular}

${ }^{1}$ Some values have been adjusted slightly from original measurements to align striae with their great circle when plotted. 
Figure 3.3. Stereoplots of shear fractures and straie observed in oriented core samples from five coreholes in the Medicine Lake Volcano area. The upper stereoplot contains all of the fractures found in the sample while the lower stereoplot contains only the fractures bearing striae. Slip vectors depicted by a solid arrow are based on the observed slip sense supported by the overall pattern of $\mathrm{P}$ and $\mathrm{T}$ axes. Slip vectors depicted by a dashed arrow indicate the slip sense inferred by the overall pattern of $\mathrm{P}$ and $\mathrm{T}$ axes when the slip sense was ambiguous. Slip vectors depicted by opposing solid and dashed arrows respectively indicate the very low confidence unambiguous observed sense and the contradictory inferred sense based on the overall pattern of P-T axes. Slip vectors depicted by opposing solid and dotted arrows respectively indicate the unambiguous observed sense and the contradictory inferred sense based on the overall pattern of P-T axes. 

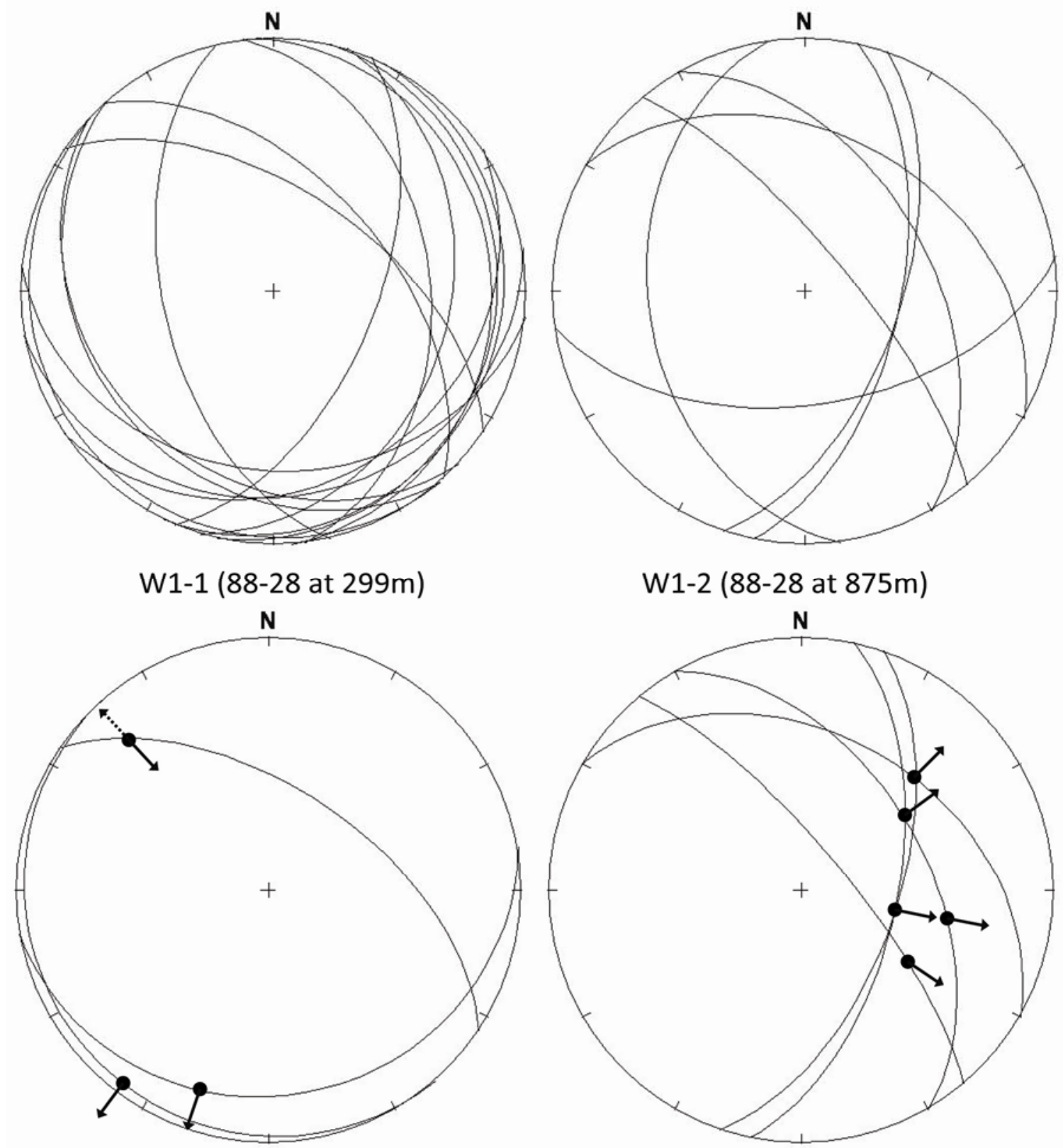

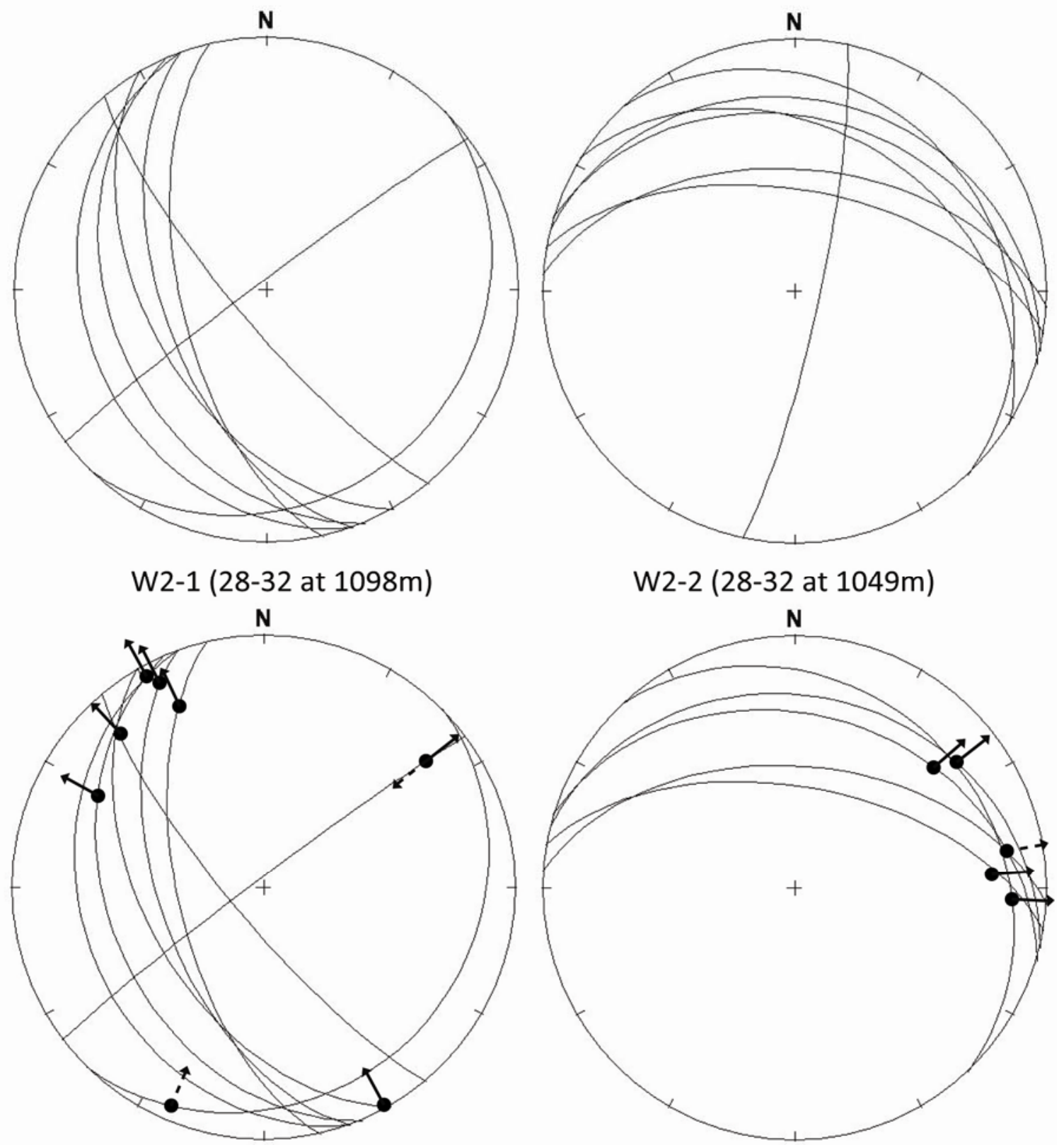

Figure 3.3 (continued) 


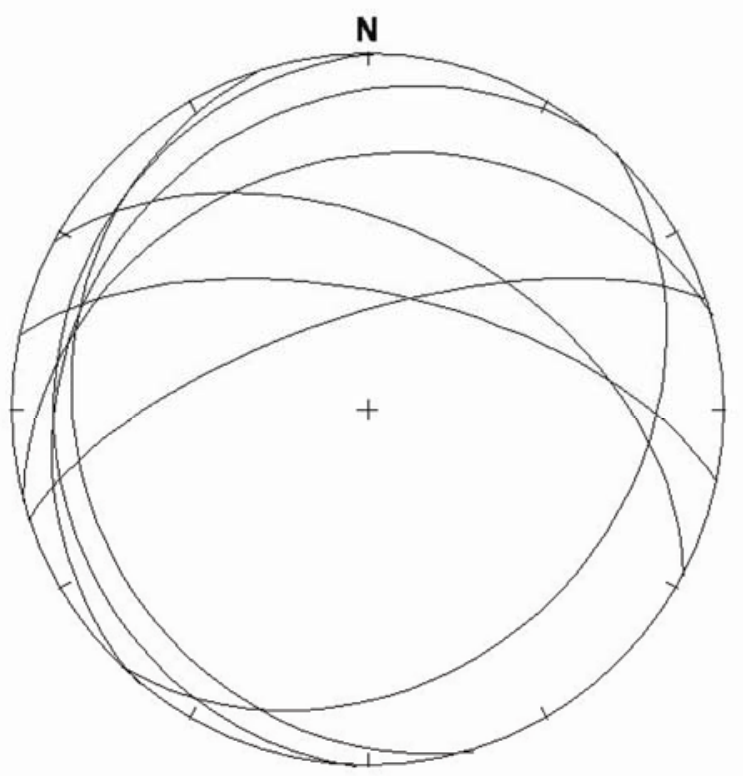

Combined W3-1 and W3-2 (14-23 at 792m)

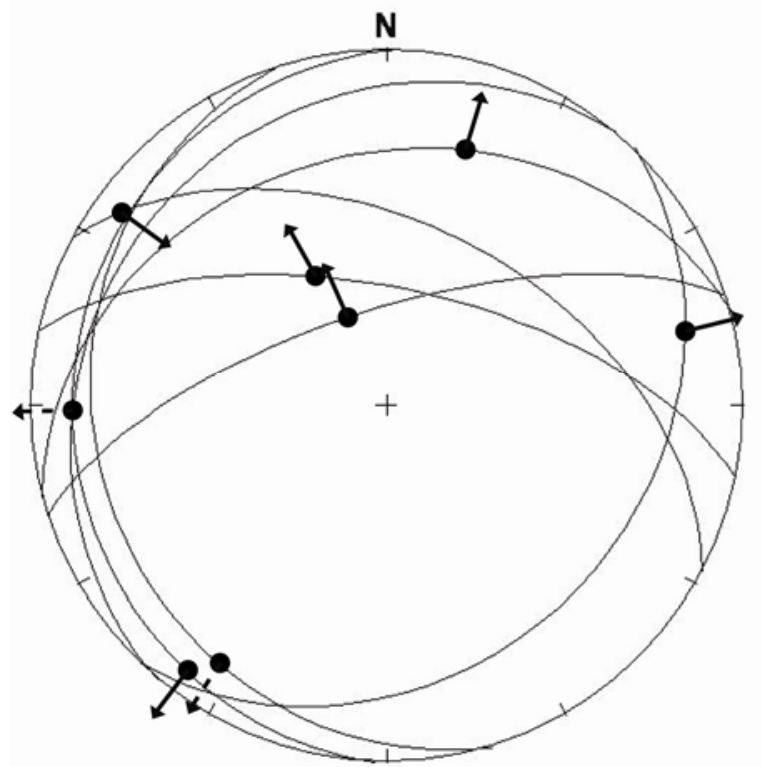

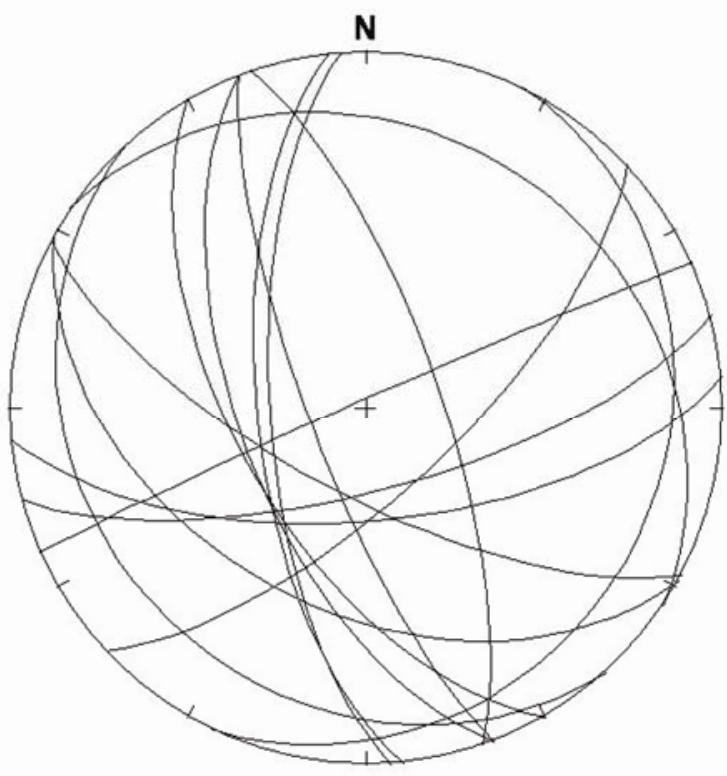

W3-3 (1423 at 816m)

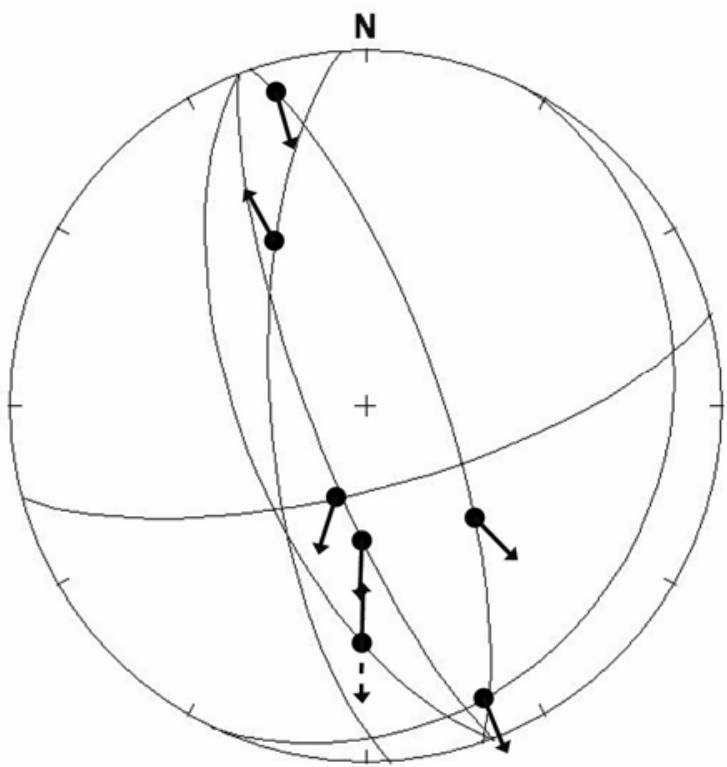

Figure 3.3 (continued) 

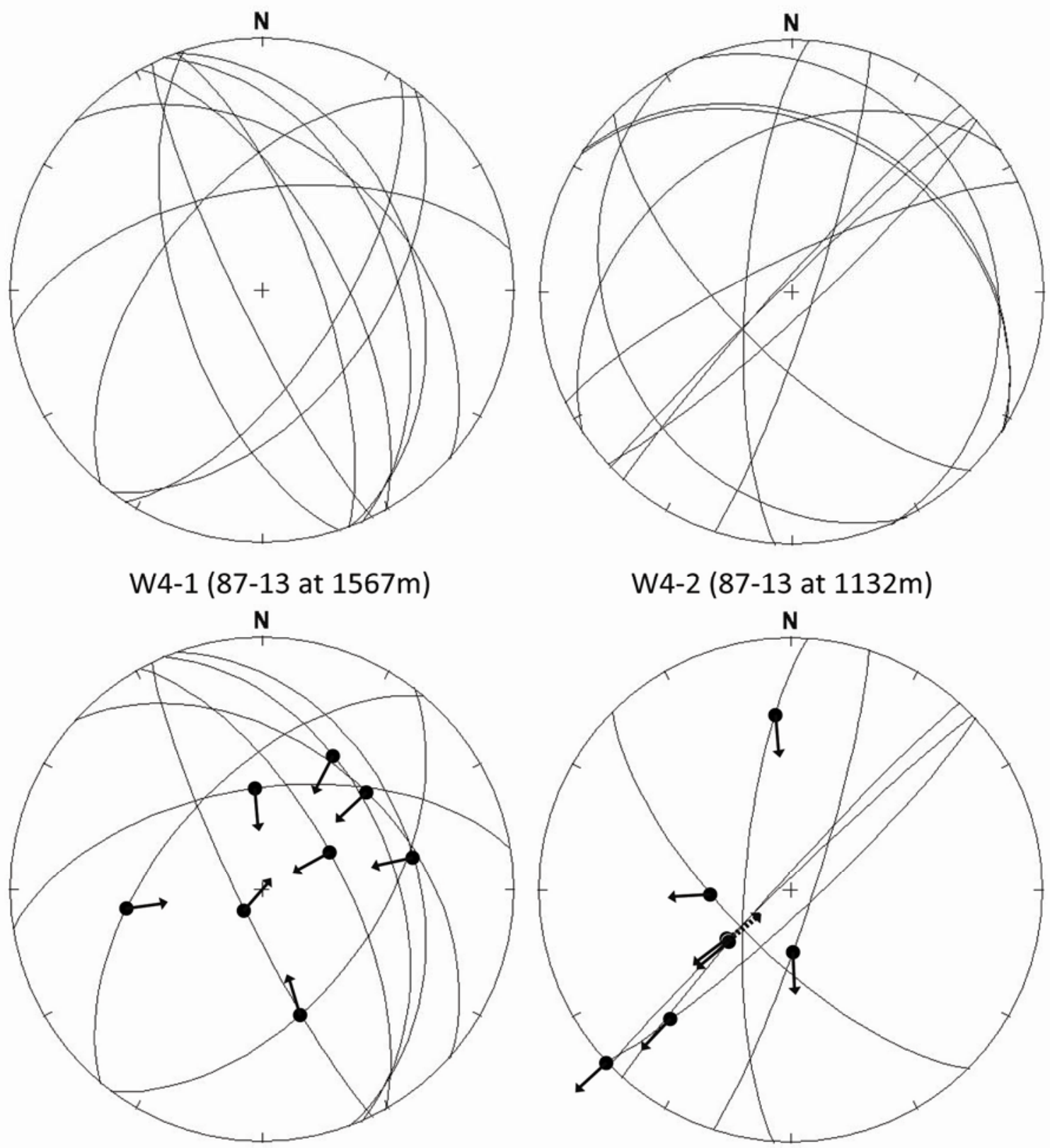

Figure 3.3 (continued) 

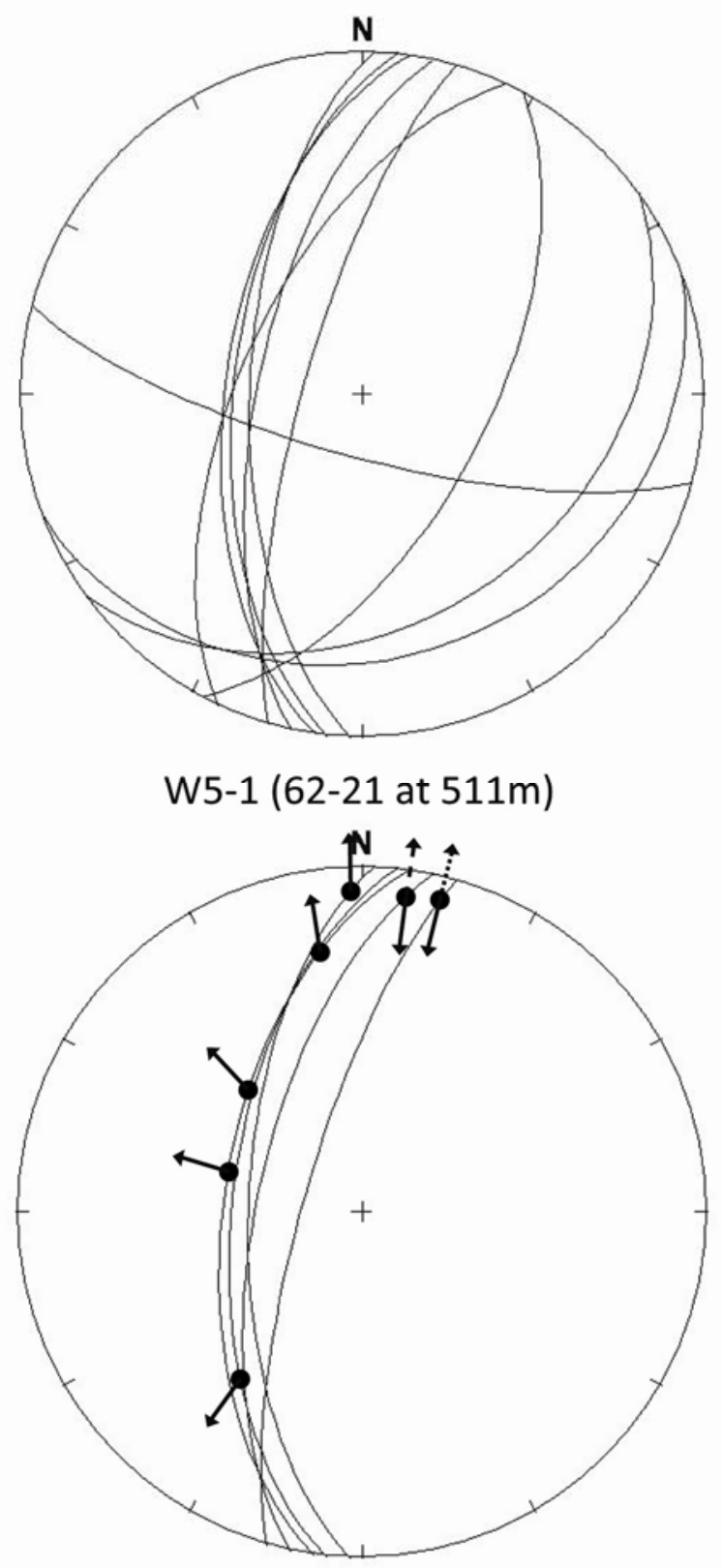

Figure 3.3 (continued) 
Figure 3.4. Plots of $\mathrm{P}$ and $\mathrm{T}$ axes of striated shear fractures in oriented core samples from five coreholes in the Medicine Lake Volcano area. Contractional (P) axes are depicted by red triangles. Tensional (T) axes are depicted by black circles. Letters near each axis correspond to the striae set designators listed in Table 3.2. Boxes indicate cases where the axes for an ambiguous striae set were inferred from the overall pattern. Dashed circles indicate that the plotted axes based on questionably unambiguous striae are contradictory to the overall pattern. Dotted circles indicate that the plotted axes based on unambiguous striae as observed are contradictory to the overall pattern. 


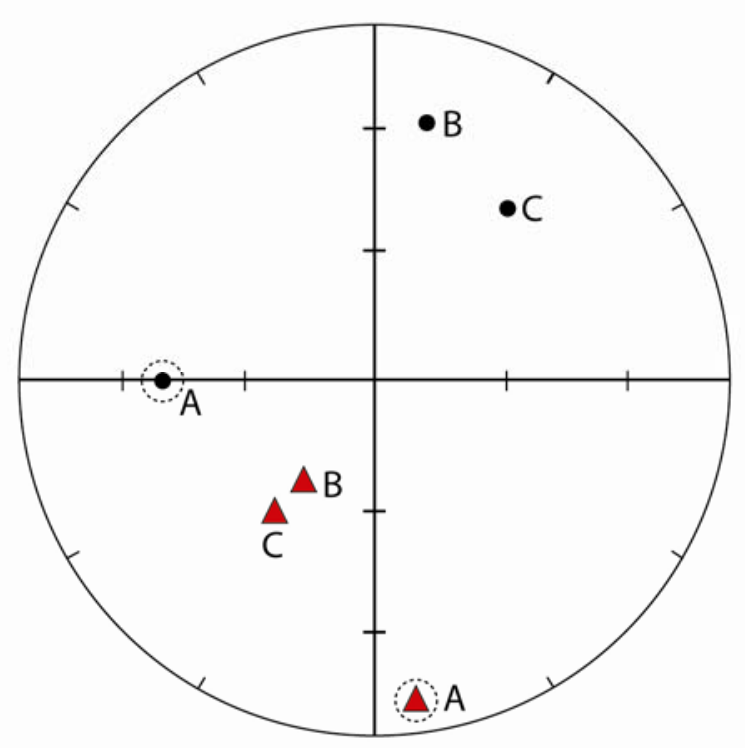

W1-1 (88-28 at 299m)

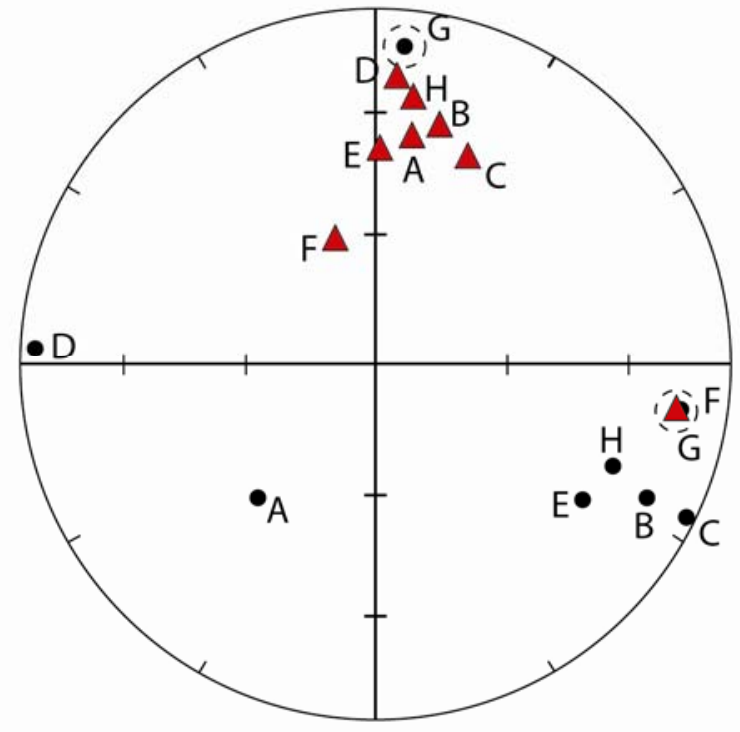

W2-1 (28-32 at 1098m)

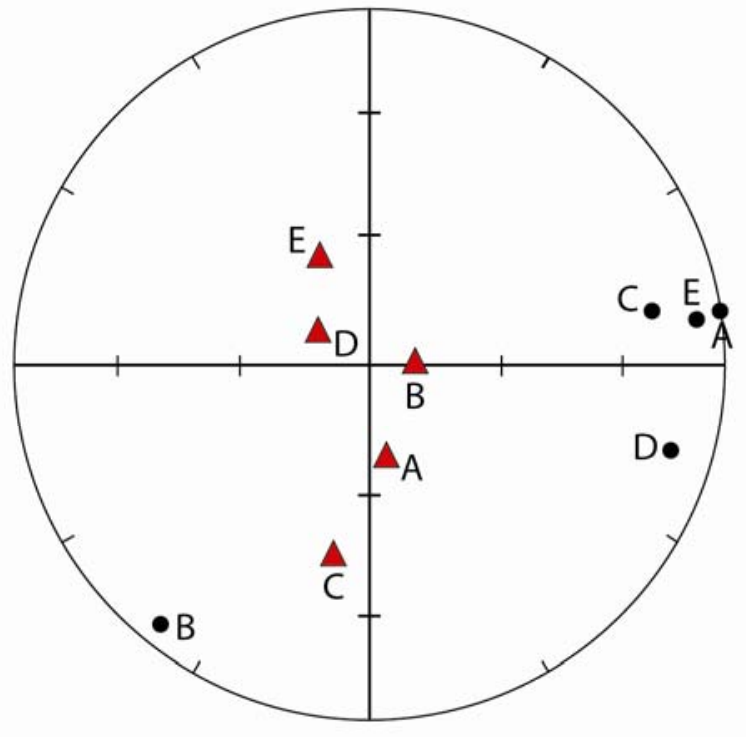

W1-2 (88-28 at 875m)

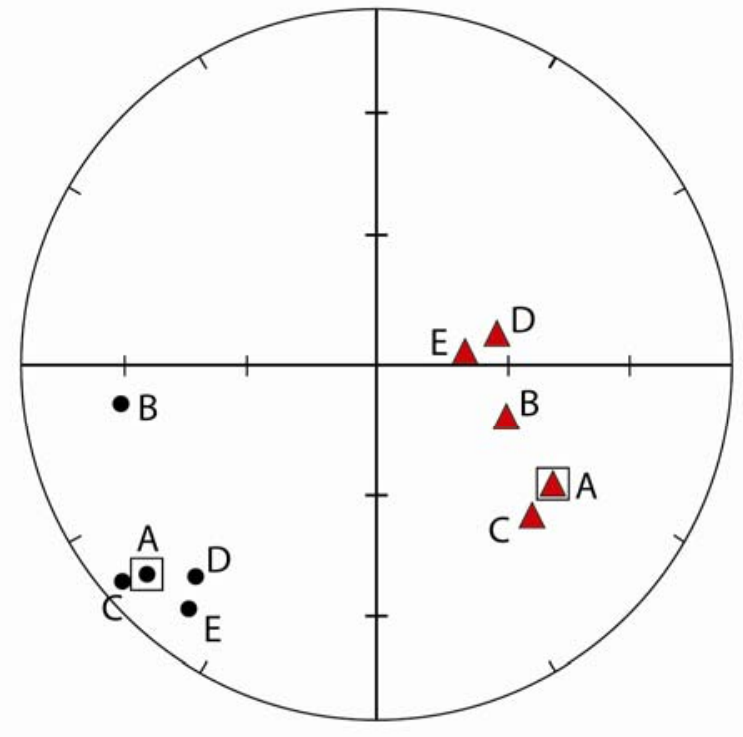

W2-2 (28-32 at 1049m) 


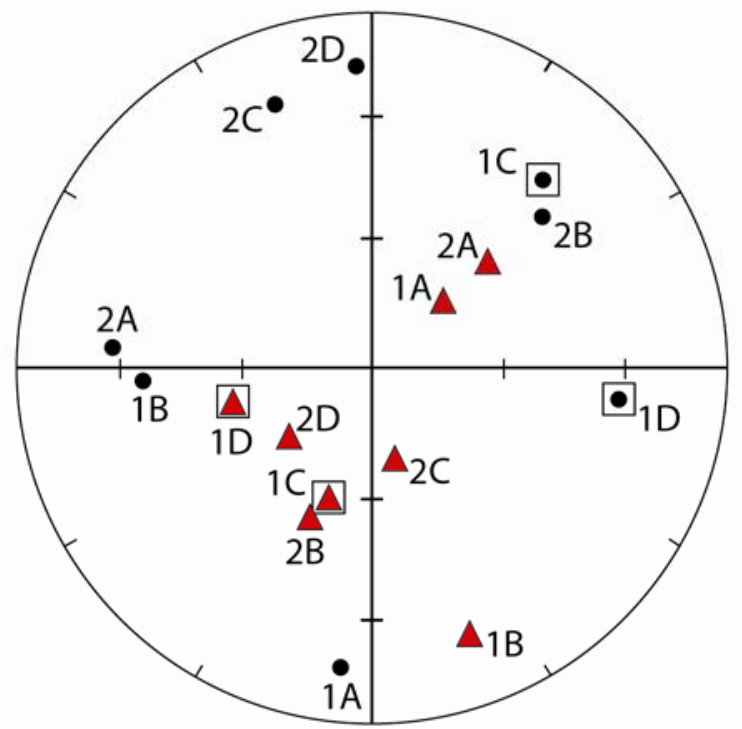

Combined W3-1 and

W3-2 (14-23 at 792m)

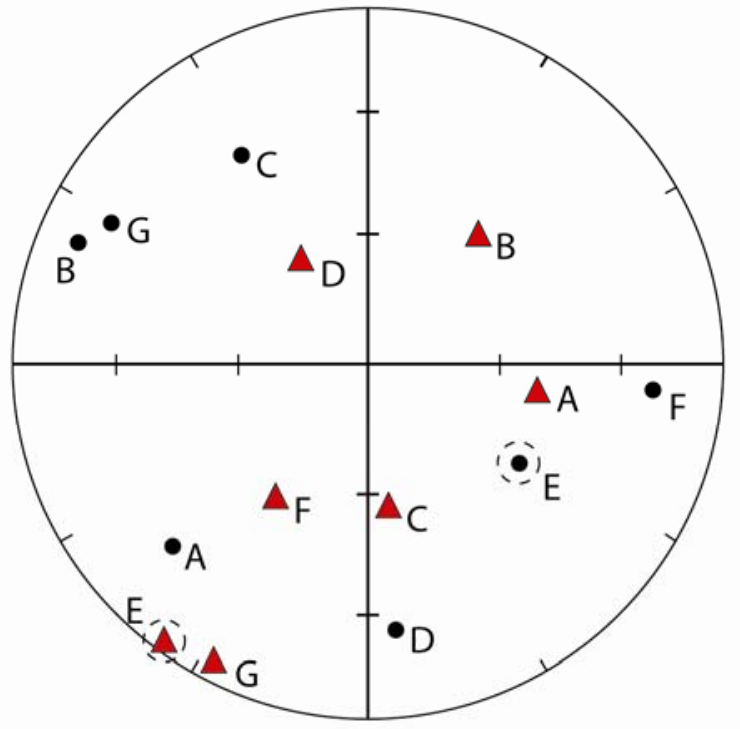

W3-3 (1423 at 816m)

Figure 3.4 (continued) 


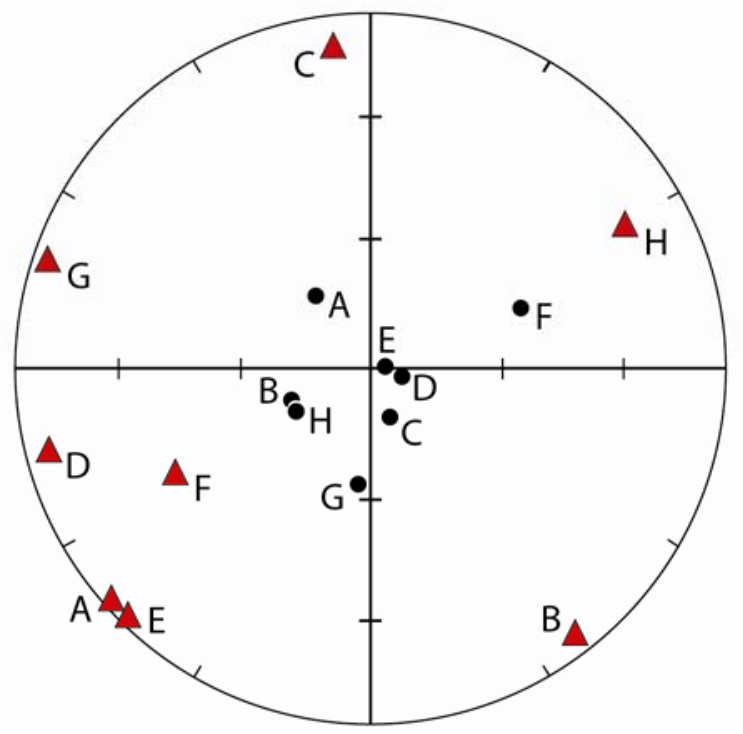

W4-1 (87-13 at 1567m)

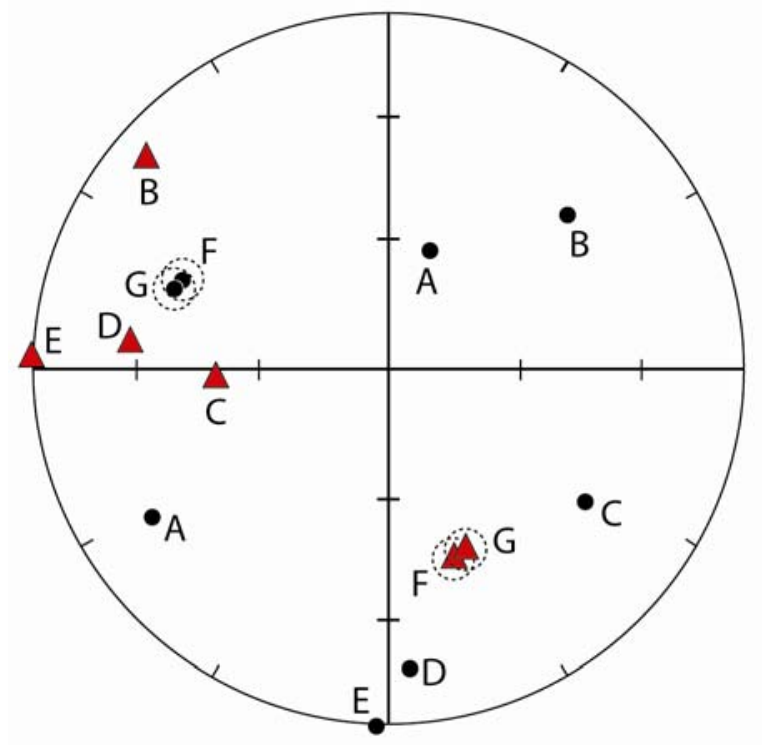

W4-2 (87-13 at $1132 \mathrm{~m})$

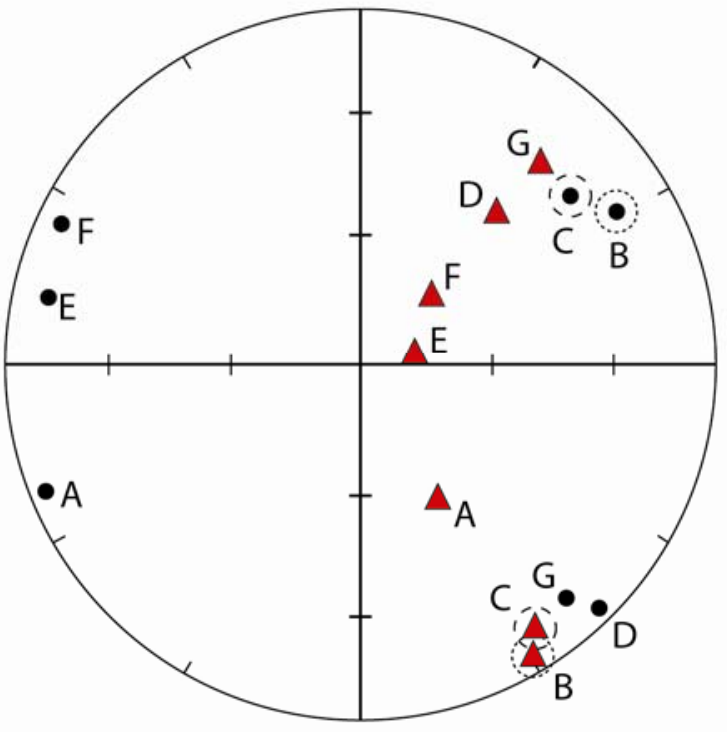

W5-1 (62-21 at 511m)

Figure 3.4 (continued) 
sets were used for all calculations and the contradictions between the observed senses and the $\mathrm{P}$ and $\mathrm{T}$ axis-inferred senses are simply noted in the text and illustrated in Figures 3.3 and 3.4. The inferred senses based on the $\mathrm{P}$ and $\mathrm{T}$ axes were used in cases where the observed sense was ambiguous. The plots of the $\mathrm{P}$ and $\mathrm{T}$ axes were also used to characterize the overall kinematic signature recorded in each well (Table 3.3) by calculating the overall extension and contraction directions.

\section{General Observations}

Fracture dips vary considerably among the five coreholes. GMF 88-28 and GMF 87-13 each contain a horizontal fracture and GMF 87-13 also contains a nearly vertical fracture. However, the majority of fractures in most samples dip moderately $\left(31-60^{\circ}\right)$ or steeply $\left(61-90^{\circ}\right)$.

When all fractures in a given interval are considered, samples W2-1, W2-2 (GMF 28-32), and W5-1 (ML 62-21) vary the least in strike, while fracture orientations in the other samples are more complex. If only striated fractures in each sample interval are considered, the strike directions are commonly more uniform.

In general, the shear sense varies from normal to dextral and most fractures display a combination of the two. Sample W4-1 from GMF 87-13 exhibits reverse slip with small components of sinistral and dextral shear. Only five other fractures in the remaining samples contain any component of reverse shear and the reverse component in all but one is small. 
Table 3.3

Fracture and overall extension and contraction orientations of paleomagnetically oriented core and three field study sites in the Medicine Lake Volcano area.

\begin{tabular}{|c|c|c|c|c|c|c|c|c|c|}
\hline \multirow[b]{2}{*}{ Sample / Site } & \multirow[b]{2}{*}{ Well/TGH } & \multicolumn{2}{|c|}{$\begin{array}{l}\text { Average Dip Azimuth } \\
\text { (Deg.) }\end{array}$} & \multirow[b]{2}{*}{$\begin{array}{l}\text { Range for } \\
\text { All } \\
\text { Fractures }\end{array}$} & \multicolumn{2}{|c|}{ Fracture Dip Data (Deg.) } & \multirow[b]{2}{*}{$\begin{array}{l}\text { Average } \\
\text { for Striated } \\
\text { Fractures }\end{array}$} & \multicolumn{2}{|c|}{$\begin{array}{l}\text { P-T Axes Overall } \\
\text { Trend/Plunge (Deg.) }\end{array}$} \\
\hline & & $\begin{array}{l}\text { All } \\
\text { Fractures }\end{array}$ & $\begin{array}{l}\text { Striated } \\
\text { Fractures }\end{array}$ & & $\begin{array}{l}\text { Average } \\
\text { for All } \\
\text { Fractures }\end{array}$ & $\begin{array}{l}\text { Range for } \\
\text { Striated } \\
\text { Fractures }\end{array}$ & & Contraction & Extension \\
\hline W1-1 & GMF $88-28$ & 074 & 207 & $5-57$ & 31 & $5-57$ & 27 & $199 / 53$ & $017 / 38$ \\
\hline W1-2 & & 069 & 069 & $38-76$ & 53 & $38-76$ & 56 & $210 / 83$ & 079/09 \\
\hline Combined & & & & & & & & $203 / 70$ & $070 / 10$ \\
\hline W2-1 & GMF $28-32$ & 253 & 253 & $18-87$ & 52 & $18-87$ & 52 & $009 / 36$ & $112 / 15$ \\
\hline W2-2 & & 022 & 018 & $21-82$ & 43 & $21-57$ & 37 & $113 / 56$ & $230 / 18$ \\
\hline Combined & & & & & & & & $032 / 52$ & $258 / 05$ \\
\hline W3-1, W3-2 & ML 14-23 & 324 & 324 & $13-68$ & 36 & $13-68$ & 36 & $222 / 72$ & $006 / 14$ \\
\hline W3-3 & & 236 & 263 & $17-88$ & 58 & $17-77$ & 61 & $189 / 67$ & $121 / 00$ \\
\hline Combined & & & & & & & & $208 / 72$ & $143 / 00$ \\
\hline W4-1 & GMF87-13 & 076 & 070 & $39-82$ & 58 & $39-82$ & 55 & $242 / 04$ & $201 / 86$ \\
\hline W4-2 & & 312 & 292 & $0-87$ & 55 & $70-87$ & 81 & $289 / 24$ & $337 / 05$ \\
\hline \multicolumn{10}{|l|}{ Combined $^{1}$} \\
\hline W5-1 & ML 62-21 & 289 & 279 & $24-76$ & 57 & $57-76$ & 64 & $081 / 62$ & $098 / 5$ \\
\hline Site 14 & - & - & & - & - & $17-86$ & 63 & $069 / 17$ & $318 / 09$ \\
\hline Site 15 & - & - & & - & - & $22-75$ & 34 & $078 / 62$ & $311 / 17$ \\
\hline Site 18 & - & - & & - & - & $20-88$ & 42 & $323 / 70$ & $230 / 04$ \\
\hline
\end{tabular}

${ }^{1}$ No calculations were made for the combined set because the samples do not seem to be related (reverse vs. normal shear). 
W1-1 (GMF 88-28)

Fracture orientations in this sample are widely scattered. Fracture dips are generally shallow, with $60 \%$ dipping at $30^{\circ}$ or less. Only three of the fifteen fractures contain slip striae. All striae were of poor quality, and thus the slip sense for each was assigned a low confidence level. Normal and normal-dextral slip was observed on two shallowly dipping fractures (striae sets "B" and "C"). Striae set "A" appeared to have a significant dextral component, but the pattern of P-T axes for the sample (Fig. 3.4) suggest that it may be sinistral.

\section{W1-2 (GMF88-28)}

Fracture orientations in this sample are scattered, but the average dip direction is similar to that of W1-1. Moderate dips are characteristic of $86 \%$ of the fractures in this sample. Striae are present on five of the seven fractures. The slip sense for all striae indicates primarily normal displacement to the east.

\section{W1-1 and W1-2 Combined}

Because only three striae were recorded from W1-1, the P-T plots were combined with W1-2 to calculate the maximum extension direction for the well as a whole. This combined set indicates primarily normal displacement.

\section{W2-1 (GMF 28-32)}

This sample exhibits fairly coherent fracture orientations. The distribution of dip angles is scattered fairly evenly between shallow, moderate, and steep. All eight fractures exhibited striae. Confidence in the dextral slip sense for striae set "G" was low and striae set "A" was indeterminate. Both of these striae sets were on fractures oriented 
considerably differently from the moderate dips to the SW of the others. The P-T groupings suggest that both of these striae sets may be sinistral.

\section{W2-2 (GMF 28-32)}

Fracture orientation is generally coherent in this sample. Although shallow and steep dips are also present in this sample, $57 \%$ dip moderately. Five of the seven fractures contain striae. Four of the striae sets indicate normal shear with a dextral component. The sense of displacement for the remaining fracture (striae set "A") could not be determined. However, the grouping of $\mathrm{P}$ and $\mathrm{T}$ axes suggests that it is also normal-dextral.

\section{W3-1 and W3-2 (ML 14-23)}

The strikes of fractures in these samples vary widely and half of the fractures dip shallowly. All eight fractures contain slip striae. Striae set "2 B" was questionably normal in sense and the senses of two others (striae sets "1C" and "1D") could not be determined. The pattern of $\mathrm{P}$ and $\mathrm{T}$ axes suggests that all three accommodated normal slip.

\section{W3-3 (ML 14-23)}

Fracture orientations in this sample are extremely scattered. Most fractures (73\%) dip steeply. This interval contains 15 fractures, but striae were found on only six. Four of the six strike NNW-SSE and dip steeply, one to the east and three to the west. The east-dipping fracture is striated in two directions, one of which is dextral (younger) while the other is normal with a moderate dextral component (older). Another steeply dipping 
striated fracture strikes approximately $90^{\circ}$ to these four fractures. The remaining striated fracture dips shallowly to the southeast.

The observed senses of four of the seven striae sets ("B”, "D”, “E”, and "G”) were questionable. However, the overall pattern of the P-T axes suggests that the observed slip sense of three of the four questionable sets is correct, while the sense of the remaining set ("E") may be opposite to the observed sense.

\section{W3-1, W3-2, and W3-3 Combined}

All three samples were combined in order to characterize the overall kinematic signature observed in this well. The P-T axes in the combined set show primarily normal faulting with some strike-slip movement.

\section{W4-1 (GMF 87-13)}

Fracture orientations in this sample are scattered. Dip angles are almost evenly divided between moderate and steep. Eight of 11 fractures contain striae and the orientations of these fractures are more coherent: five strike NNW-SSE and the others strike roughly NE-SW. All striae record predominantly reverse shear, and some include small components of dextral or sinistral displacement. The reverse sense of striae set "F" was questionable, but the $\mathrm{P}$ and $\mathrm{T}$ axis groupings suggest the sense is indeed reverse.

\section{W4-2 (GMF 87-13)}

Fracture strikes in this sample are widely scattered. Just over half of the fractures dip steeply. There are 13 fractures in this interval but only six exhibit striae. These six fractures have more coherent orientations: five strike between N-S and NE-SW and the other strikes NW-SE. One of the fractures contains two sets of striae. One set records 
pure dextral shear while the other is dextral with a moderate component of normal slip. The sinistral sense of striae set "B" was questionable, but the $\mathrm{P}$ and $\mathrm{T}$ axis groupings suggest the sense is sinistral.

$$
\text { W5-1 (ML 62-21) }
$$

This sample contains somewhat scattered fracture orientations. However, the five striated fractures are very coherent in dip direction and angle. Steep dips characterize $60 \%$ of the fractures and most of the remainder dip moderately. The dip directions of the striated fractures vary between $272^{\circ}$ and $286^{\circ}$. Striae observations indicated a mix of normal, dextral, and sinistral shear. However, the P-T axis pattern derived from the other five striae sets suggests that the two sinistral-slip striae ("B" and "C"), of which set "C" was questionable, may be dextral. The grouping of the $\mathrm{P}$ and $\mathrm{T}$ axes also suggests that striae set "A", questionably indicating normal-sinistral displacement, is likely correct.

\section{$\underline{\text { Field Work }}$}

The data presented here are unpublished observations made in 2006 by Dr. Michal Nemčok from the Energy and Geoscience Institute at the University of Utah. They are summarized here with his permission. The field study locations are shown in Figure 2.4. Field data include measured shear fractures, joints, and striae (Table 3.4) along with faults and fissures (Table 3.5). Fractures with striae where the shear sense could be determined were found only at Sites 14, 15, and 18. These sites, along with Site 7, are the only locations where fractures in multiple orientations were observed. Stereoplots (Fig. 3.5) show the orientations of shear fractures, striae, and slip senses at Sites 14, 15, and 18. Plots of calculated P and T axes (Fig. 3.5) were constructed and 
Table 3.4

Fracture, joint, and striation data from field study sites in the Medicine Lake Volcano area.

\begin{tabular}{|c|c|c|c|c|c|c|c|c|c|c|}
\hline \multirow[b]{2}{*}{ Site } & \multirow[b]{2}{*}{ Feature } & \multirow[b]{2}{*}{$\begin{array}{l}\text { Fracture }(F) \\
\text { Joint }(J)\end{array}$} & \multirow[b]{2}{*}{ Rock Type } & \multirow[b]{2}{*}{$\begin{array}{l}\text { Strike } \\
\text { (Deg.) }\end{array}$} & \multicolumn{2}{|l|}{ Fracture } & \multicolumn{2}{|c|}{ Striation } & \multirow[b]{2}{*}{$\begin{array}{l}\text { Observed } \\
\text { Slip Sense }\end{array}$} & \multirow[b]{2}{*}{$\begin{array}{l}\text { P-T Inferred } \\
\text { Slip Sense }\end{array}$} \\
\hline & & & & & $\begin{array}{l}\text { Dip } \\
\text { Azimuth } \\
\text { (Deg.) }\end{array}$ & $\begin{array}{l}\text { Dip } \\
\text { (Deg.) }\end{array}$ & $\begin{array}{l}\text { Trend } \\
(\text { Deg. })^{1}\end{array}$ & $\begin{array}{l}\text { Plunge } \\
\text { (Deg.) }\end{array}$ & & \\
\hline 1 & $\mathrm{a}$ & $\mathrm{J}$ & Sandstone & 170 & 260 & 80 & $\mathrm{~N} / \mathrm{A}$ & $\mathrm{N} / \mathrm{A}$ & N/A & $\mathrm{N} / \mathrm{A}$ \\
\hline 7 & $\mathrm{a}$ & $\mathrm{F}$ & Basalt & 155 & 245 & 85 & 156 & 15 & UNK-SS & N/A \\
\hline 7 & $\mathrm{~b}$ & $\mathrm{~F}$ & & 312 & 042 & 55 & 090 & 43 & UNK-OS & N/A \\
\hline 7 & $\mathrm{c}$ & $\mathrm{F}$ & & 326 & 056 & 60 & 115 & 42 & UNK-OS & N/A \\
\hline 7 & $\mathrm{~d}$ & $\mathrm{~F}$ & & 198 & 288 & 82 & 018 & 00 & UNK-SS & N/A \\
\hline 7 & $\mathrm{e}$ & $\mathrm{F}$ & & 184 & 274 & 65 & 199 & 30 & UNK-SS & N/A \\
\hline 8 & $\mathrm{a}$ & $\mathrm{F}$ & Andesite & 331 & 061 & 79 & 342 & 45 & UNK-OS & N/A \\
\hline 9 & $\mathrm{a}$ & $\mathrm{F}$ & Andesite & 049 & 139 & 72 & 221 & 23 & UNK-SS & N/A \\
\hline 11 & $\mathrm{a}$ & $\mathrm{F}$ & Andesite & 356 & 084 & 35 & 013 & 13 & $\mathrm{UNK} \mathrm{SS}^{3}$ & N/A \\
\hline 14 & $\mathrm{a}$ & $\mathrm{F}$ & Andesite & 027 & 117 & 67 & 200 & 17 & Dextral & Dextral \\
\hline 14 & $\mathrm{~b}$ & $\mathrm{~F}$ & & 179 & 269 & 85 & 185 & 51 & Dextral & Dextral \\
\hline 14 & $\mathrm{c}$ & $\mathrm{F}$ & & 179 & 269 & 85 & 355 & 39 & Sinistral & Dextral \\
\hline 14 & $\mathrm{~d}$ & $\mathrm{~F}$ & & 149 & 239 & 86 & 176 & 81 & Unknown & Normal \\
\hline 14 & $\mathrm{e}$ & $\mathrm{F}$ & & 098 & 188 & 80 & 100 & 10 & Sinistral & Sinistral \\
\hline 14 & $\mathrm{f}$ & $\mathrm{F}$ & & 063 & 153 & 17 & 098 & 10 & Unknown & Sinistral \\
\hline 14 & $\mathrm{~g}$ & $\mathrm{~F}$ & & 097 & 187 & 45 & 108 & 10 & Unknown & Sinistral \\
\hline
\end{tabular}




\begin{tabular}{|c|c|c|c|c|c|c|c|c|c|c|}
\hline \multirow[b]{2}{*}{ Site } & \multirow[b]{2}{*}{ Feature } & \multirow[b]{2}{*}{$\begin{array}{l}\text { Fracture }(F) \\
\text { Joint }(J)\end{array}$} & \multirow[b]{2}{*}{ Rock Type } & \multirow[b]{2}{*}{$\begin{array}{l}\text { Strike } \\
\text { (Deg.) }\end{array}$} & \multirow{2}{*}{$\begin{array}{l}\text { Fracture } \\
\text { Dip } \\
\text { Azimuth } \\
\text { (Deg.) }\end{array}$} & \multirow[b]{2}{*}{$\begin{array}{l}\text { Dip } \\
\text { (Deg.) }\end{array}$} & \multicolumn{2}{|c|}{ Striation } & \multirow[b]{2}{*}{$\begin{array}{l}\text { Observed } \\
\text { Slip Sense }^{2}\end{array}$} & \multirow[b]{2}{*}{$\begin{array}{l}\text { P-T Inferred } \\
\text { Slip Sense }\end{array}$} \\
\hline & & & & & & & $\begin{array}{l}\text { Trend } \\
(\text { Deg. })^{1}\end{array}$ & $\begin{array}{l}\text { Plunge } \\
\text { (Deg.) }\end{array}$ & & \\
\hline 15 & $\mathrm{a}$ & $\mathrm{F}$ & Andesite & 074 & 164 & 75 & 077 & 11 & Unknown & Sinistral \\
\hline 15 & $\mathrm{~b}$ & $\mathrm{~F}$ & & 088 & 178 & 22 & 098 & 04 & Dextral & Sinistral \\
\hline 15 & $\mathrm{c}$ & $\mathrm{F}$ & & 051 & 141 & 25 & 103 & 20 & Normal & Normal \\
\hline 15 & $\mathrm{~d}$ & $\mathrm{~F}$ & & 070 & 160 & 35 & 112 & 25 & Sinistral & Sinistral \\
\hline 15 & $\mathrm{e}$ & $\mathrm{F}$ & & 071 & 161 & 29 & 112 & 20 & Normal & Normal \\
\hline 15 & $\mathrm{f}$ & $\mathrm{F}$ & & 090 & 180 & 28 & 136 & 21 & Unknown & Normal \\
\hline 15 & $\mathrm{~g}$ & $\mathrm{~F}$ & & 062 & 152 & 30 & 116 & 25 & Unknown & Normal \\
\hline 15 & $\mathrm{~h}$ & $\mathrm{~F}$ & & 098 & 188 & 29 & 136 & 19 & Unknown & Sinistral \\
\hline 18 & $\mathrm{a}$ & $\mathrm{F}$ & Andesite & 093 & 183 & 88 & 272 & 27 & Unknown & Dextral \\
\hline 18 & $\mathrm{~b}$ & $\mathrm{~F}$ & & 135 & 225 & 55 & 259 & 50 & Unknown & Normal \\
\hline 18 & $\mathrm{c}$ & $\mathrm{F}$ & & 080 & 170 & 62 & 249 & 20 & Dextral & Dextral \\
\hline 18 & $\mathrm{~d}$ & $\mathrm{~F}$ & & 197 & 287 & 20 & 236 & 13 & Unknown $^{3}$ & Sinistral $^{3}$ \\
\hline 18 & e & $\mathrm{F}$ & & 047 & 137 & 27 & 053 & 03 & Sinistral & Sinistral \\
\hline 18 & $\mathrm{f}$ & $\mathrm{F}$ & & 128 & 218 & 22 & 225 & 22 & Unknown & Normal \\
\hline 18 & $\mathrm{~g}$ & $\mathrm{~F}$ & & 282 & 012 & 23 & 043 & 20 & Unknown & Normal \\
\hline
\end{tabular}

${ }^{1}$ Some values have been adjusted slightly from original measurements to align striae with their great circle when plotted.

${ }^{2}$ In cases where the slip sense could not be determined or inferred, the type of slip (Strike, Oblique, or Dip) is noted.

${ }^{3}$ Possible glacial origin. 
Table 3.5

Fault and fissure data from field study sites in the Medicine Lake Volcano area.

\begin{tabular}{llllllll}
\hline Site & Feature & $\begin{array}{l}\text { Fault } \\
\text { (FLT) } \\
\text { Fissure } \\
\text { (FIS) }\end{array}$ & $\begin{array}{l}\text { Rock } \\
\text { Type }^{1}\end{array}$ & $\begin{array}{l}\text { Strike } \\
\text { (Deg.) }\end{array}$ & $\begin{array}{l}\text { Dip } \\
\text { Azimuth } \\
\text { (Deg.) }\end{array}$ & $\begin{array}{l}\text { Dip } \\
\text { (Deg.) }\end{array}$ & Notes \\
\hline 2 & $\mathrm{a}$ & FLT & EPI & 015 & 105 & 84 & Note 1 \\
\hline 3 & $\mathrm{a}$ & FLT & BAS & 014 & 104 & 90 & Note 2 \\
\hline 4 & $\mathrm{a}$ & FLT & BAS & 015 & 105 & 90 & Note 3 \\
\hline 5 & $\mathrm{a}$ & FIS & BAS & 019 & 109 & 41 & Note 4 \\
5 & $\mathrm{~b}$ & FIS & & 020 & 110 & 90 & \\
5 & $\mathrm{c}$ & FIS & & 023 & 113 & 90 & \\
\hline 6 & $\mathrm{a}$ & FLT & Fluvial & 254 & 344 & 67 & Note 5 \\
6 & $\mathrm{~b}$ & FLT & SS and & 175 & 265 & 90 & Note 6 \\
6 & $\mathrm{c}$ & FLT & CGL & 157 & 247 & 90 & Note 7 \\
\hline 10 & $\mathrm{a}$ & FIS & RHY/BAS & 002 & N/A & N/A & Note 8 \\
\hline 12 & $\mathrm{a}$ & FIS & Not & 293 & N/A & N/A & Note 9 \\
12 & $\mathrm{~b}$ & FIS & Recorded & 030 & N/A & N/A & \\
\hline 13 & $\mathrm{a}$ & FLT & Coarse & 266 & 356 & 46 & Note 10 \\
13 & $\mathrm{~b}$ & FLT & SS and & 246 & 336 & 40 & Note 11 \\
13 & $\mathrm{c}$ & (Bedding) & CGL & 043 & 133 & 19 & Note 12 \\
13 & $\mathrm{~d}$ & FLT & & 284 & 014 & 42 & Note 13 \\
13 & $\mathrm{e}$ & (Bedding) & & 310 & 040 & 44 & Note 14 \\
\hline
\end{tabular}


(Table 3.5 Cont.)

\begin{tabular}{llllllll}
\hline Site & Feature & $\begin{array}{l}\text { Fault } \\
\text { (FLT) }\end{array}$ & $\begin{array}{l}\text { Rock } \\
\text { Fissure } \\
\text { (FIS) }\end{array}$ & $\begin{array}{l}\text { Strike } \\
\text { (Deg.) }\end{array}$ & $\begin{array}{l}\text { Dip } \\
\text { Azimuth } \\
\text { (Deg.) }\end{array}$ & $\begin{array}{l}\text { Dip } \\
\text { (Deg.) }\end{array}$ & Notes \\
\hline 16 & a & FIS & BAS & 280 & N/A & N/A & Note 15 \\
16 & b & FIS & & 140 & N/A & N/A & \\
\hline 17 & a & FIS & BAS & 030 & N/A & N/A & \\
\hline 19 & a & FLT & AND & 315 & UNK & UNK & Note 16 \\
\hline 20 & a & FIS & BAS & 327 & N/A & N/A & \\
\hline
\end{tabular}

${ }^{1} \mathrm{EPI}=$ Epiclastic Deposit; $\mathrm{SS}=$ Sandstone; $\mathrm{CGL}=$ Conglomerate; $\mathrm{RHY}=$ Rholite; AND $=$ Andesite; BAS $=$ Basalt

Note 1: Fault forms a valley flank.

Note 2: Fault controls a step in morphology.

Note 3: Fault scarp controlled by jointed blocks of basalt.

Note 4: En echelon fissures splaying off a strike-slip fault (a fourth fissure was not measured).

Note 5: Southern boundary fault (see text).

Note 6: Strike-slip fault linking Site 5 fissures (see text).

Note 7: Secondary strike-slip fault (see text).

Note 8: Fissure in basalt flow overlain by rhyolite.

Note 9: Two crossing fissure segments, with the vent probably at the crossing point. Fissures are empty, suggesting that material was blown out.

Note 10: Main fault at southeastern location (see text).

Note 11: Synthetic fault at southeastern location (see text).

Note 12: Bedding between 13a and 13b faults.

Note 13: Main fault at northwestern location (see text).

Note 14: Bedding in the hanging wall of $13 \mathrm{~d}$ fault (see text).

Note 15: Arcuate fissure system with two limbs.

Note 16: 8-10 m vertical offset crosscutting a basalt flow. 
Figure 3.5. Stereoplots and plots of $\mathrm{P}$ and $\mathrm{T}$ axes of shear fractures and straie observed in outcrop in the Medicine Lake Volcano area. The shear-sense could not be determined for any of the striae at Site 7 . Stereoplot slip vectors depicted by a solid arrow are based on the observed slip sense supported by the overall pattern of $\mathrm{P}$ and T axes. Slip vectors depicted by a dashed arrow indicate the slip sense inferred by the overall pattern of $P$ and $\mathrm{T}$ axes when the observed slip sense was ambiguous. Slip vectors depicted by opposing solid and dotted arrows respectively indicate the unambiguous observed sense and the contradictory inferred sense based on the overall pattern of P-T axes. In the lower plots, the contractional $(\mathrm{P})$ axes are depicted by red triangles and the tensional $(\mathrm{T})$ axes are depicted by black circles. Letters near each axis plot correspond to the straie designators listed in Table 3.4. Boxes indicate cases where the axes for an ambiguous striae set were inferred from the overall pattern. Dotted circles indicate that the plotted axes based on unambiguous striae as observed are contradictory to the overall pattern. 


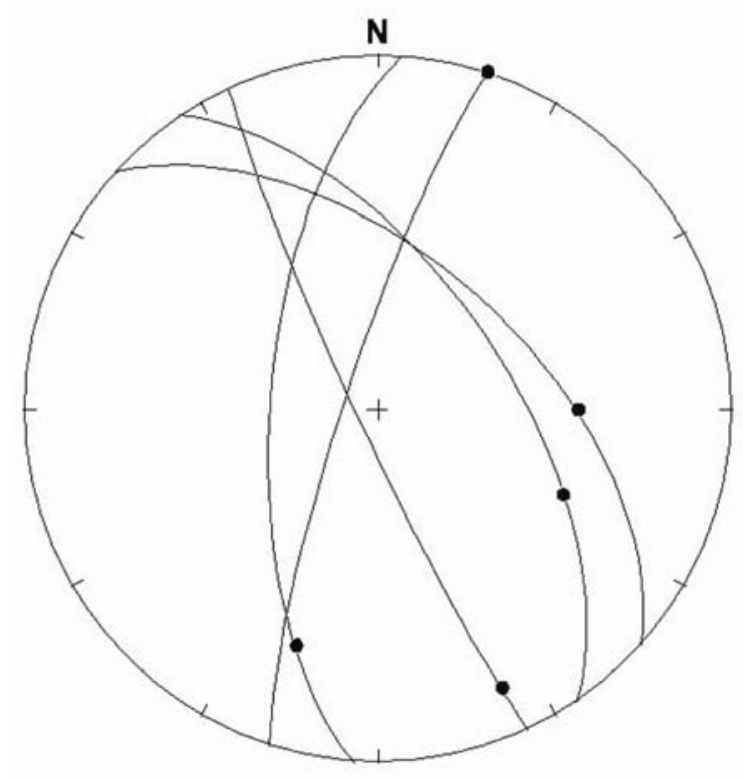

Site 7

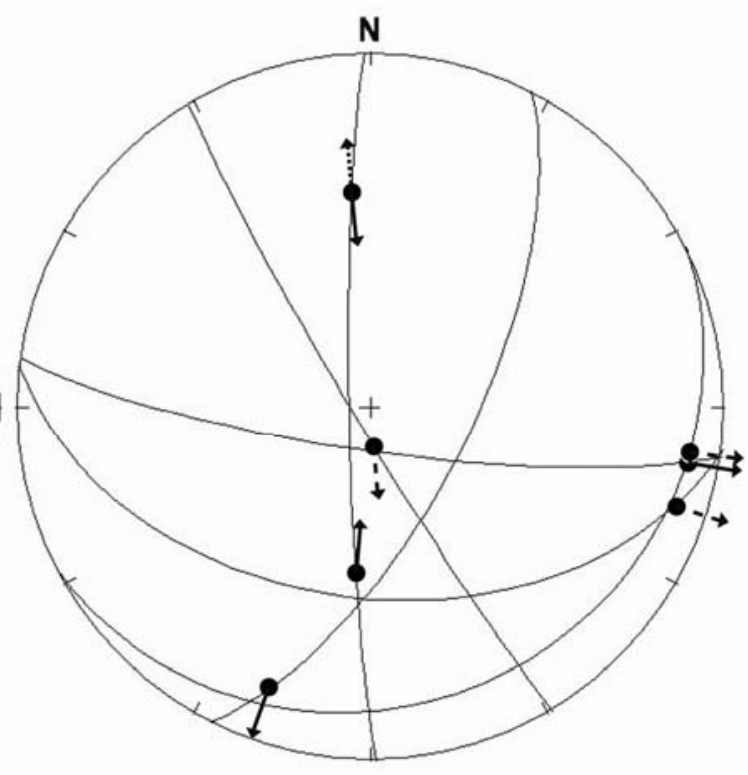

Site 14

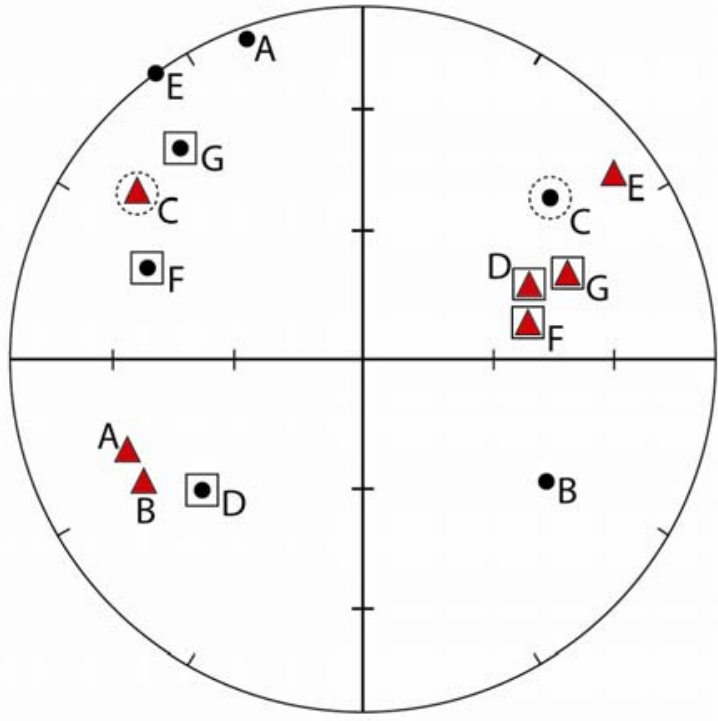



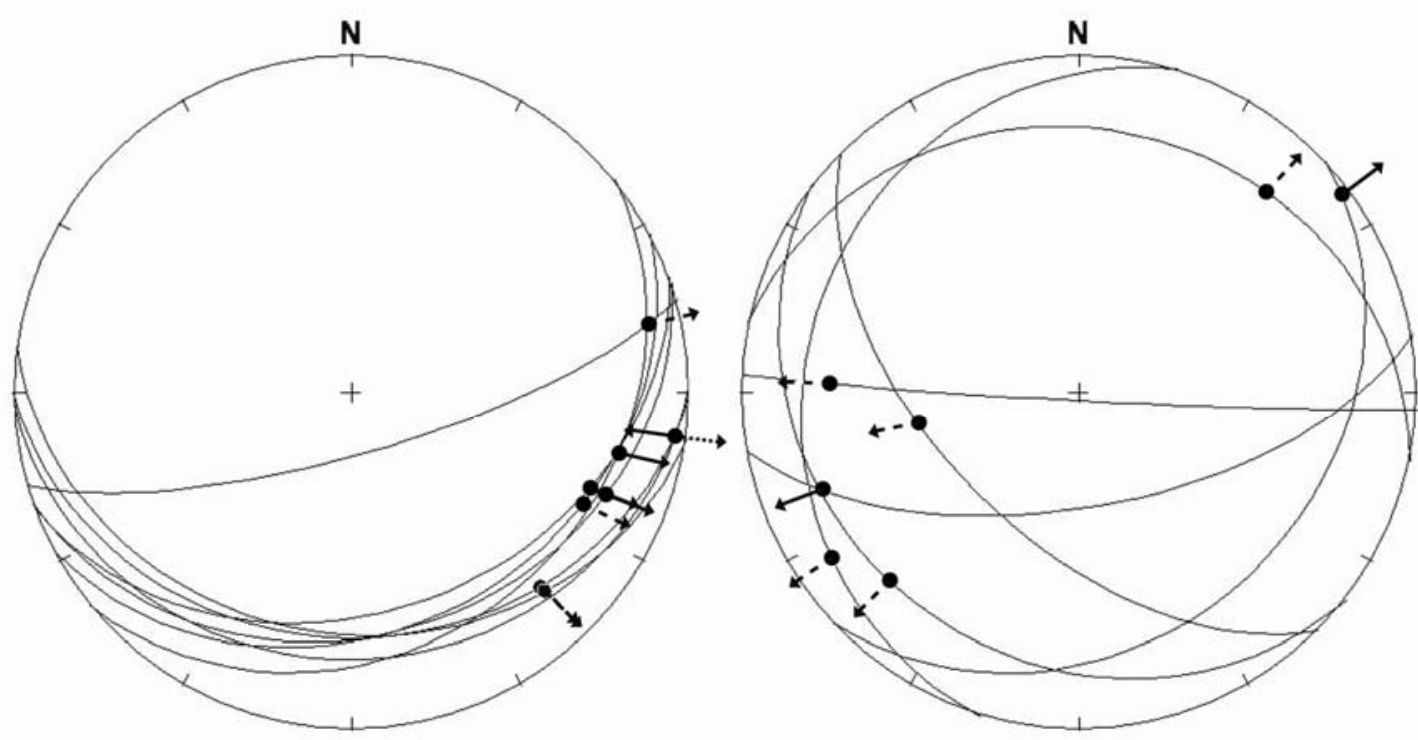

Site 15

Site 18
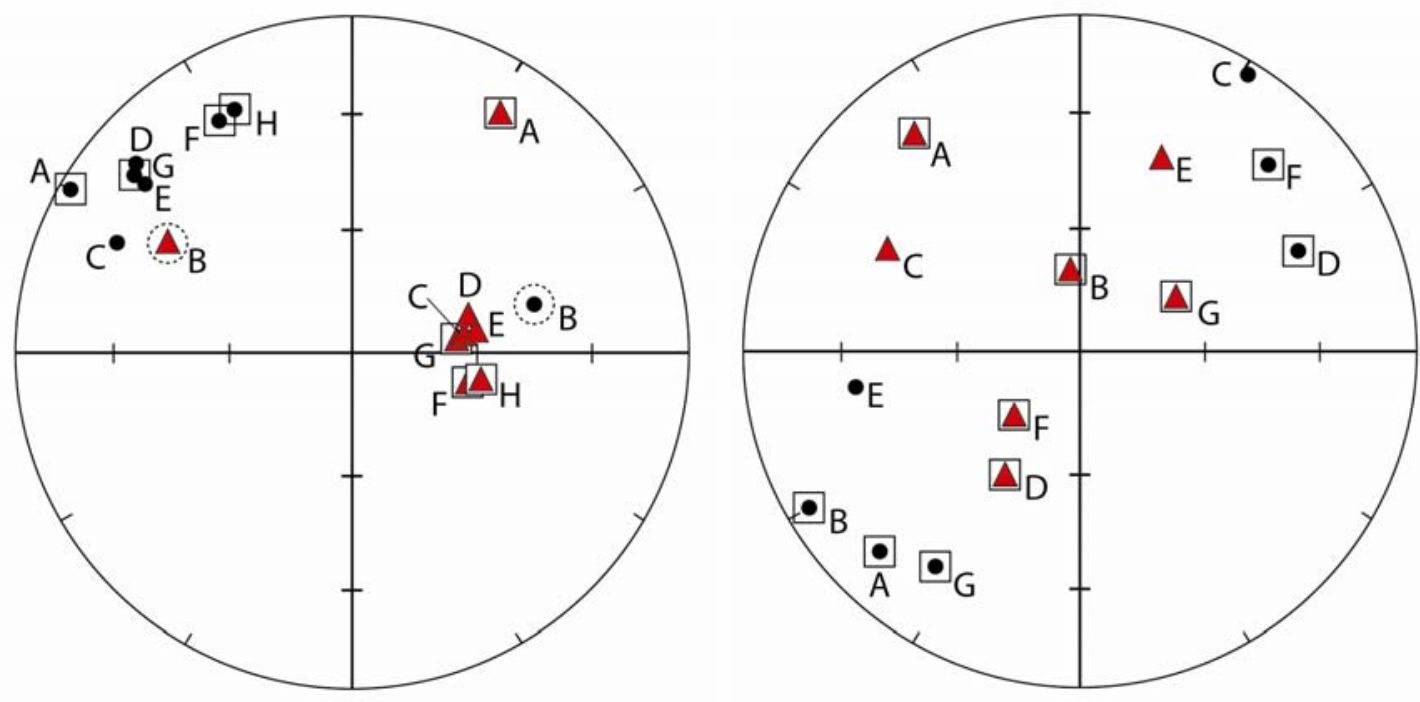

Figure 3.5 (continued) 
used in the same manner as for the oriented core study. The pattern of $\mathrm{P}$ and $\mathrm{T}$ axes were used to infer the slip senses of 12 striae sets where the slip sense could not be determined, although one of these may have a glacial origin. The patterns of $\mathrm{P}$ and $\mathrm{T}$ axes also suggests that two other striae sets could have a sense opposite to the observed sense. The calculated overall extension and contraction directions for these three sites (Table 3.3) are based on each unambiguous observed slip sense and the inferred sense for the 12 ambiguous striae sets.

The faults described at Sites 2, 3, and 4 are located along segments of the GillemBig Crack Fault system described by Bryant (2000a). The Site 10 and Site 17 fissures are located along faults or lineaments mapped by Union (1975), as are the fracture sets of Sites 11 and 15. The fault observed at Site 19 is part of the Mayfield Fault Zone (Bryant, 1995). The remaining sites do not correlate to any mapped faults although some are on strike with, but at some distance from, mapped features.

While Tables 3.4 and 3.5 adequately describe most sites, those requiring a more in-depth description are described below.

Site 5: Yellow Butte West (Table 3.5)

The site is on strike, though about $4 \mathrm{~km}$ south, of a mapped fault segment (California Department of Natural Resources, 1958). Four en-echelon fissures form a horse-tail structure as they splay off of a strike-slip fault. The horse tail forms the northern boundary of a small basin expressed in present-day morphology. 
Site 6: Yellow Butte South (Table 3.5)

This site is 600 meters SSE of Site 5. The primary fault at this site forms the southern boundary of the basin noted at Site 5 . The host rock is a fluvial deposit containing sandstone and conglomerates. Two strike-slip faults, one of which links with the fissures at Site 5, are also present in the vicinity of this site.

\section{Site 13: Newell Peninsula (Table 3.5)}

The footwall and portions of the hanging wall of a fault are exposed in the cliff face at two locations about 250 meters apart. Several synthetic faults are visible in the footwall at each location and an antithetic fault is also exposed at the northwestern location. Bedding dips are moderate in the hanging wall at the northwestern location and shallow in the footwall at the southeastern location.

\section{Site 14: Medicine Lake Flow Area (Tables 3.3 and 3.4)}

This site is located in the northwest quadrant of the topographic ring, and is on strike between two mapped fault segments about $1.5 \mathrm{~km}$ apart (California Department of Natural Resources, 1958). Seven sets of slickensides (Fig. 3.5) were observed in an andesite lava flow with some iron oxides, chlorite and chalcedony alteration. Striae sets $14 \mathrm{~b}$ (older) and $14 \mathrm{c}$ (younger) were found on the same fracture surface. Striae set $14 \mathrm{c}$ was observed to be sinistral with a fairly large reverse component. However, the pattern of $\mathrm{P}$ and $\mathrm{T}$ axes (Fig. 3.5) suggests that the low confidence 14c set may be dextralnormal. Additionally, the P and T patterns allowed the slip senses for striae sets 14d, 14f, and $14 \mathrm{~g}$, which could not be determined in the field, to be inferred. 
Site 15: Grouse Hill (Tables 3.3 and 3.4)

This site is also located within the northwest quadrant of the topographic ring, about 90 meters east of a mapped NNE striking fault (California Department of Natural Resources, 1958) and about 150 meters east of another similarly striking fault (Union, 1975). Eight sets of slickensides (Fig. 3.5) were recorded in an andesite flow. The grouping of the $\mathrm{P}$ and $\mathrm{T}$ axes suggests that low confidence striae set $15 \mathrm{~b}$ may be sinistral rather than dextral. As with Site 14, the plotted P and T axes (Fig. 3.5) allowed the slip sense to be inferred for each striae set with an undetermined shear sense (sets 15a, 15f, $15 \mathrm{~g}$, and $15 \mathrm{~h})$.

Site 18: Unnamed Location in an Andesite Flow (Tables 3.3 and 3.4)

This site is located within the southwest quadrant of the topographic ring and does not appear to be related to any mapped fault locations. Seven sets of slickensides (Fig. 3.5) were measured on fractures found in an andesite flow. As with Sites 14 and 15, the plotted $\mathrm{P}$ and $\mathrm{T}$ axes allowed the slip sense to be inferred for indeterminate striae (18a, 18b, 18d, 18f, and 18g). Analysis of the P and T axes (Fig. 3.5) to infer slip sense was probably less reliable in this case than for Sites 14 and 15 since there were only two higher confidence striae sets (18c and $18 \mathrm{e})$ to use as a guide. Striae set $18 \mathrm{~h}$ may have a glacial origin. However, eliminating this set from the remaining striae sets did not appreciably change the calculated extension and contraction directions. In this case, the calculated overall extension azimuth decreased $2^{\circ}$ and maximum contraction azimuth increased $15^{\circ}$ 


\section{$\underline{\text { Magnetotelluric Maps }}$}

1712 m a.s.1. Elevation Slice (Fig. 3.6a)

Aside from a zone of moderately high resistivity near the center, resistivity values of less than $10 \mathrm{ohm}-\mathrm{m}$ comprise roughly half of the area within the topographic ring. These low resistivity values change rapidly to a generally continuous ring of high resistivity, much of it in excess of $200 \mathrm{ohm}-\mathrm{m}$, around the outside of the topographic ring. This zone is generally concentric with the topographic ring but has a radius about $1-3 \mathrm{~km}$ larger. The high resistivity zone is surrounded by a zone of moderate resistivity, generally on the order of 15-40 ohm-m, that extends to the borders of the MT study area.

\section{2 m a.s.1. Elevation Slice (Fig. 3.6b)}

The resistivity pattern for this elevation slice is similar to the $1712 \mathrm{~m}$ a.s.1. elevation slice except that resistivity levels across the whole area are generally lower. Resistivity drops about $5 \mathrm{ohm}-\mathrm{m}$ within much of the topographic ring, resulting in many zones with values of less than $5 \mathrm{ohm}-\mathrm{m}$. Many areas outside the ring reveal resistivity decreases of at least 50-100 ohm-m compared to the same areas on the $1712 \mathrm{~m}$ a.s.l. slice.

\section{2 m a.s.1. Elevation Slice (Fig. 3.6c)}

A major shift in resistivity occurs between this slice and the $1612 \mathrm{~m}$ a.s.1. slice, although the mapped resistivity pattern remains similar to the overlying slices. The most significant difference is that the ring of high resistivity surrounding the topographic trace has become a very conductive zone. Also, the moderate resistivity zone near the center 
Figure 3.6a-g. Resistivity maps based on MT data for seven selected elevation slices between 112 and 1712 masl through Medicine Lake Volcano. Elevations are in meters relative to mean seal level 

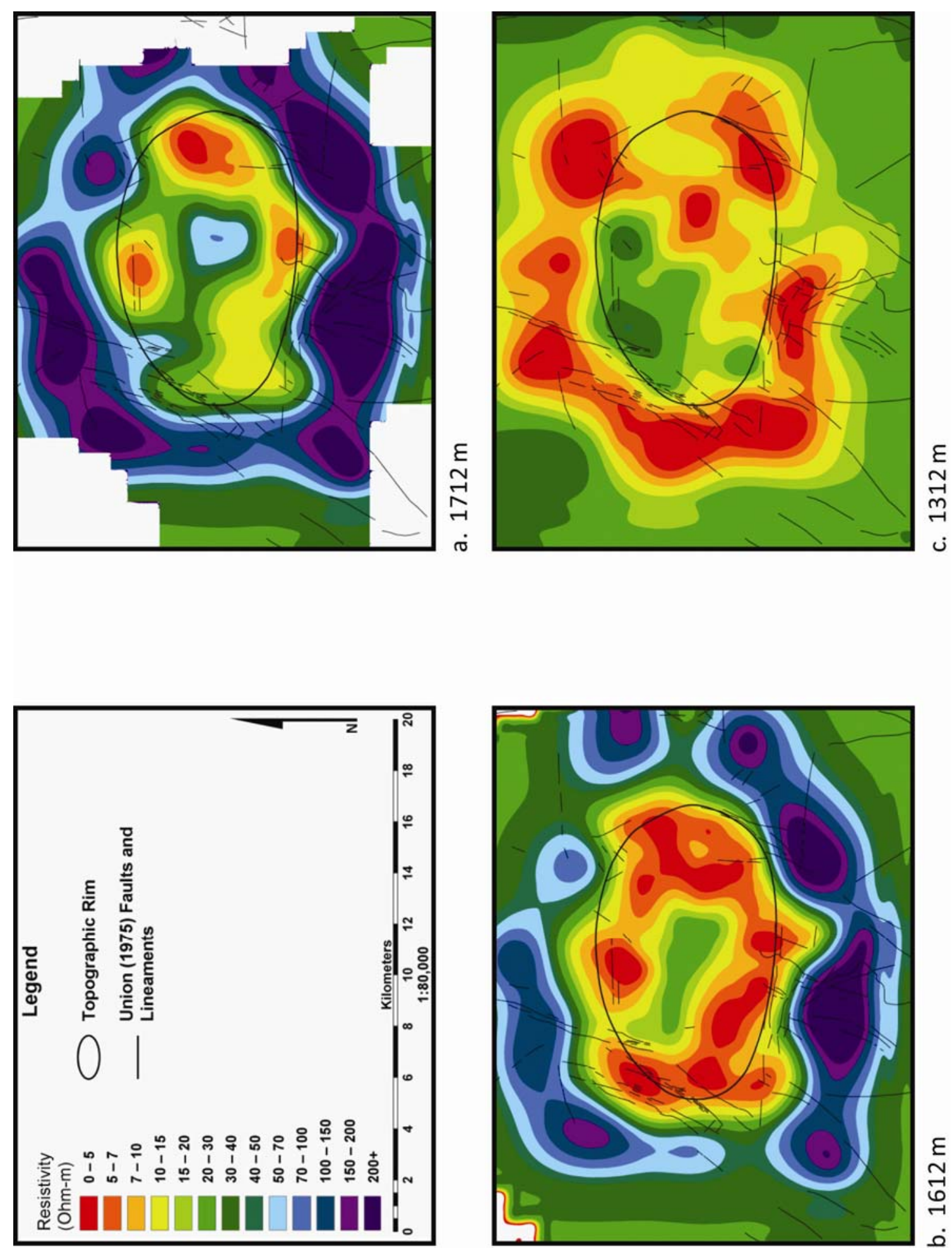

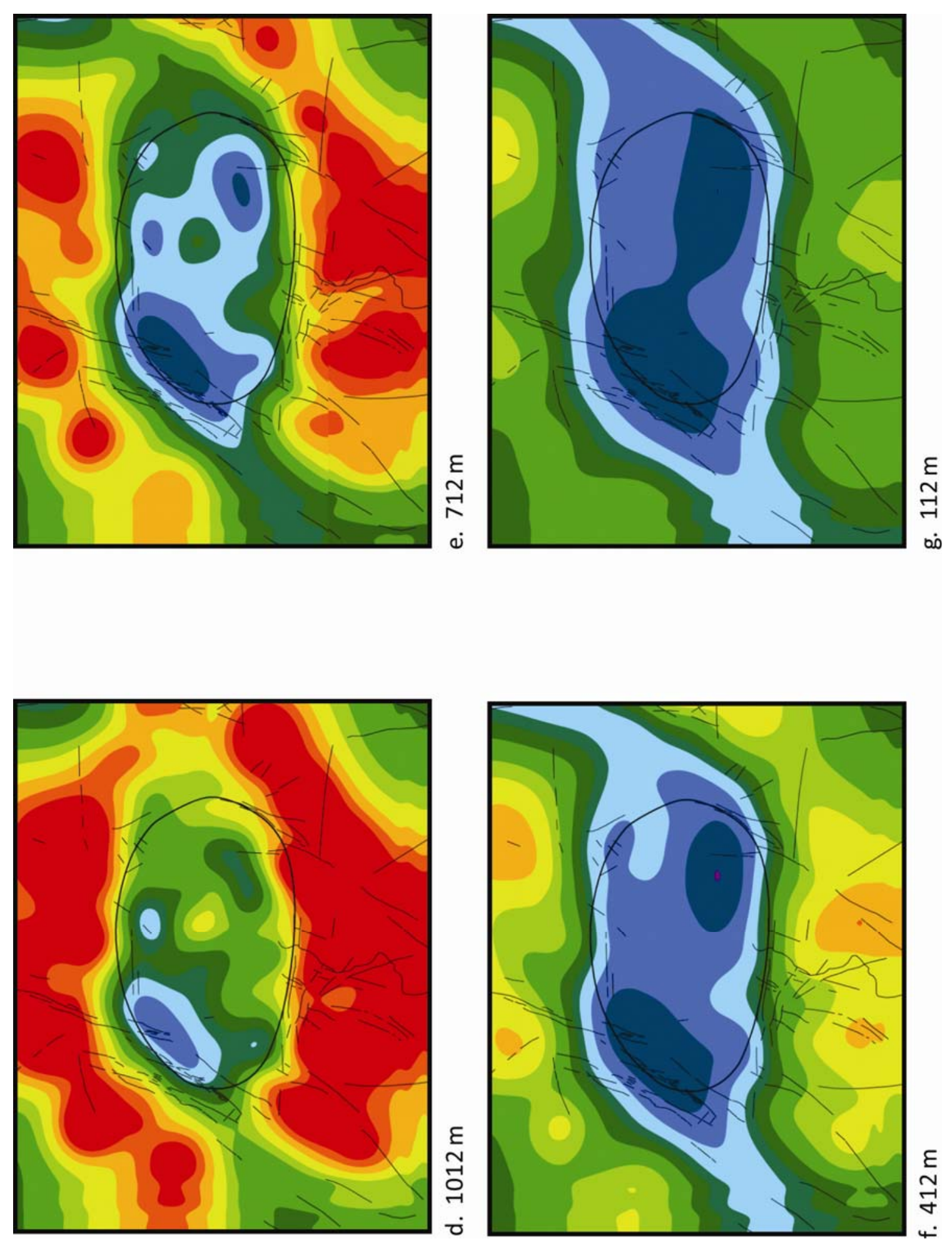

Figure 3.6a-g. (continued) 
of the topographic ring in the upper slices shifts to the northwest quadrant, and the overall resistivity within the ring is slightly higher.

1012 m a.s.1. Elevation Slice (Fig. 3.6d)

The resistivity pattern within the topographic ring broadly resembles the $1312 \mathrm{~m}$ a.s.1. elevation slice, except that this area is increasingly resistive. In contrast, the conductive zone outside of the topographic ring is wider and very conductive, except in the ENE and SW areas of the topographic ring where the resistivity generally increases.

712 m a.s.1. Elevation Slice (Fig. 3.6e)

The pattern within the topographic ring resembles the $1012 \mathrm{~m}$ a.s.l. slice and the trend of increasing resistivity continues. A slight increase in resistivity is present in most of the outlying areas. The exception to this trend is that the areas of greatly increasing resistivity near the ENE and SW margins of the topographic ring, first seen in the slice above, are better defined and extend toward the NE and SW corners of the map, respectively.

\section{2 m a.s.1. Elevation Slice (Fig. 3.6f)}

The overall pattern at this level resembles the previous elevation slice and the trend of increasing resistivity persists across the map. The pattern is characterized by a sigmoid-shaped zone of high resistivity from roughly the SW to the NE corners of the map.

\section{$112 \mathrm{~m}$ a.s.1. Elevation Slice (Fig. 3.6g)}

The trend relating to the mapped resistivity patterns and increasing resistivity established by the $412 \mathrm{~m}$ a.s.l. slice continues at this level and nearly all areas exhibit 
resistivity higher than $20 \mathrm{ohm}-\mathrm{m}$. The $12 \mathrm{~m}$ a.s.1., $-187 \mathrm{~m}$ a.s.1., and $-487 \mathrm{~m}$ a.s.1.

elevation slices all are nearly identical to the $112 \mathrm{~m}$ a.s.l. elevation slice.

\section{$\underline{\text { USGS Fault and Fold Database }}$}

Fault data were compiled from the USGS Fault and Fold database (http://earthquake.usgs.gov/regional/qfaults/) (Fig. 2.7) for the area covered by the nine $1^{\circ} \times 2^{\circ}$ sheets surrounding MLV (see tables in Appendix A). The Newberry Volcano ring faults found on the Crescent $1^{\circ} \times 2^{\circ}$ sheet were also compiled.

Most faults within the area covered by the nine $1^{\circ} \times 2^{\circ}$ sheets accommodate predominantly normal slip on NW to NNE striking faults. Aside from a few dextral faults found on the Redding sheet related to the San Andreas Fault System, there are only three faults in the nine sheet area that primarily accommodate dextral shear, although they also have a normal component of slip. These are the Warm Springs Valley (Sawyer et al., 1999) and Terraced Hills (Sawyer and Adams, 1999a) fault zones from the Lovelock sheet and the Likely Fault Zone from the Susanville sheet (Sawyer and Bryant, 1995). All three strike northwest and are roughly on strike with many other dextral faults in Walker Lane. Eleven other individual faults or fault zones have or are thought to have some dextral component on primarily normal faults. These faults are found on the Adel, Vya, Lovelock, and Susanville sheets.

The unnamed fault zone near Sand Pass in Nevada (Adams and Sawyer, 1999a) is the only fault zone in the nine sheet area that exhibits primarily sinistral offset. Additionally, five predominantly normal faults or fault zones found on the Klamath Falls, Adel, and Susanville sheets have or may have some component of sinistral shear. 
The only thrust faults in the overall area are almost $300 \mathrm{~km}$ to the southwest and are related to the transpressive San Andreas Fault System. There are relatively few faults between these western California faults and Medicine Lake Volcano.

The Mount Mazama ring faults that constitute the rim of the Crater Lake caldera within Mount Mazama, a large Quaternary stratovolcano in the Cascade Range, are located on the Medford sheet (Personius, 2002a). The ring faults of Newberry Volcano, considered by some to be analogous to MLV, are found further north on the Crescent sheet (Personius, 2002b).

Many of the faults in the Alturas (where MLV is located), Susanville, Redding, and Weed sheets only have location data available. This includes many of the faults south and southeast of MLV that strike roughly toward the volcano.

\section{Temperature Surface Model}

\section{General Observations}

All of the temperature surfaces are generally conformable, although interpolation errors resulting from sparse data do result in a few locations where a lower surface intersects a higher surface. All of the surfaces point to a thermal depression in the area of GMF 17-6 as well as thermal highs along the southern, eastern, and northwestern margins of the ring. The thermal highs to the south and east typically define a fairly continuous arcuate ridge located about 500 meters inside the volcanic rim. A thermal high is also present around the northwest section of the rim, but limited well data prevent its shape from being well defined on surfaces hotter than $50^{\circ} \mathrm{C}$. 


\section{$50^{\circ} \mathrm{C}$ Temperature Surface (Fig. 3.7a)}

The central depression roughly correlates to an isolated zone of low resistivity within the generally conductive center of the volcano on the $1712 \mathrm{~m}$ elevation MT slice. The arcuate ridge along the south and east margins of the volcanic ring correlates reasonably well with the low resistivity zones found on the $1712 \mathrm{~m}$ elevation MT slice. In contrast, the ridge near the northwest margin of the volcanic rim cuts across high and low resistivity zones on the same MT slice. The elevation of the surface drops rapidly to the north, south, and southwest of the MLV summit and is reliably supported by well data from ML 14-23, ML 29-1, ML 36-28, ML 57-13, ML 62-21, ML 65-26, and ML 86-23. The elevation of the surface appears to rise to the east, but the lack of well data in that direction suggests that this may be an artifact of the contouring process.

$100^{\circ} \mathrm{C}$ Temperature Surface (Fig. 3.7b)

This temperature surface is roughly conformable to the $50^{\circ}$ surface around the eastern $2 / 3$ of the volcanic rim. The thermal gradient is steepest on the eastern side of the volcanic rim. There are few topographic highs or lows on this surface that appear to correlate with any of the MT data.

\section{$150^{\circ} \mathrm{C}$ Temperature Surface (Fig. 3.7c)}

Well temperature data for the $150^{\circ} \mathrm{C}$ surface are sparse to the north and west, but they are adequate in the eastern $2 / 3$ of the volcanic ring. As with the cooler surfaces, the thermal gradient is steeper on the eastern side of the topographic ring compared to the western side. Aside from a possible correlation with the lower resistivity zone around 
Figure 3.7a-e. Petrel temperature surface models in map view for the $50^{\circ} \mathrm{C} \mathrm{(a),} 100^{\circ} \mathrm{C}$ (b), $150^{\circ}$ (c), $200^{\circ} \mathrm{C}(\mathrm{d})$, and $250^{\circ} \mathrm{C}$ (e) surfaces. Only wells referenced in the text for this section are shown. Wells outside the boundaries of the surface are either too shallow to intersect the specific surface or do not have temperature data available. The surfaces are irregularly shaped because the surface generation feature was set to only interpolate between data points rather than to extrapolate beyond data points. Contour interval is 100 meters. The X-axis shows UTM Easting location and the Y-axis shows the UTM Northing location. 


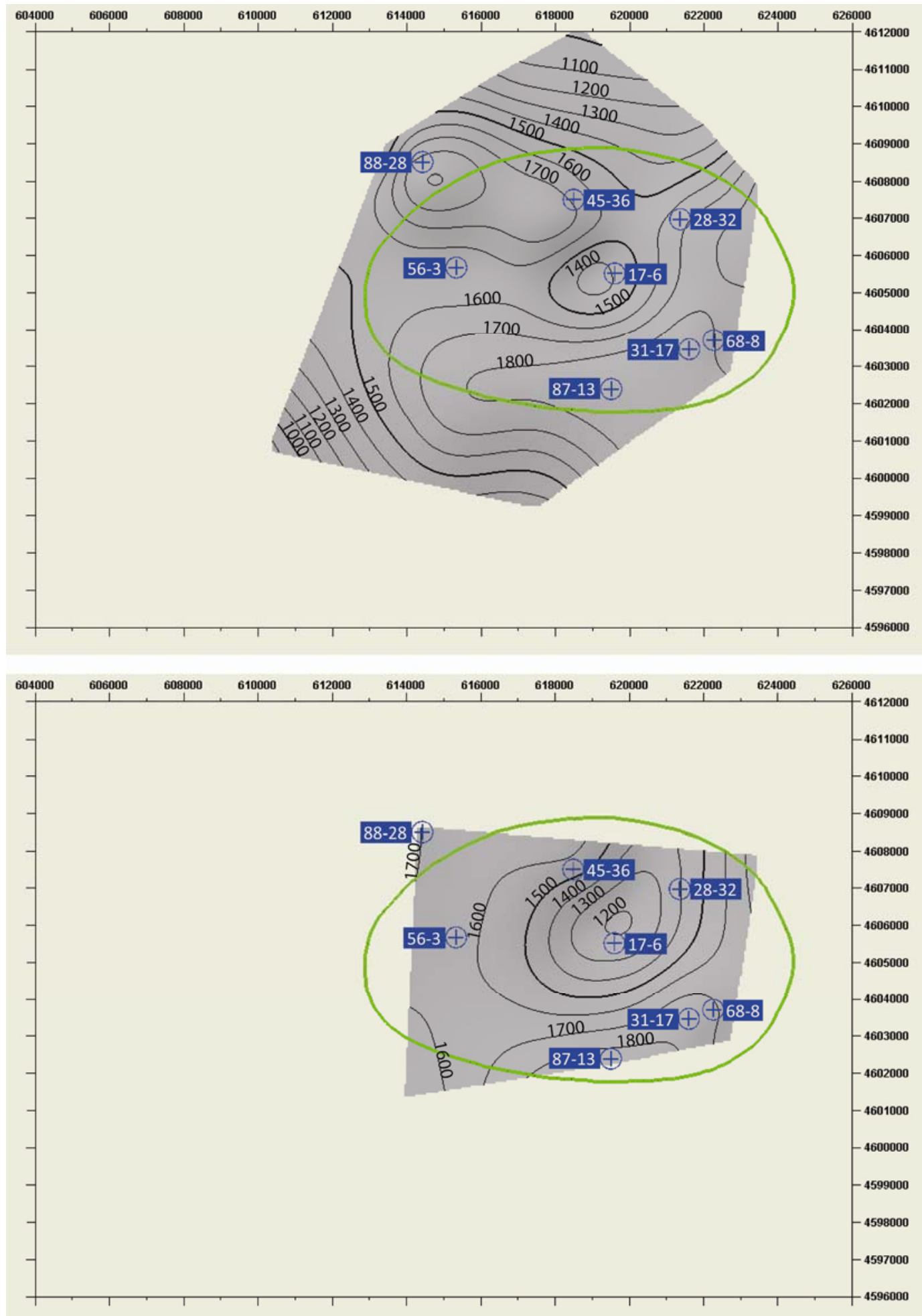




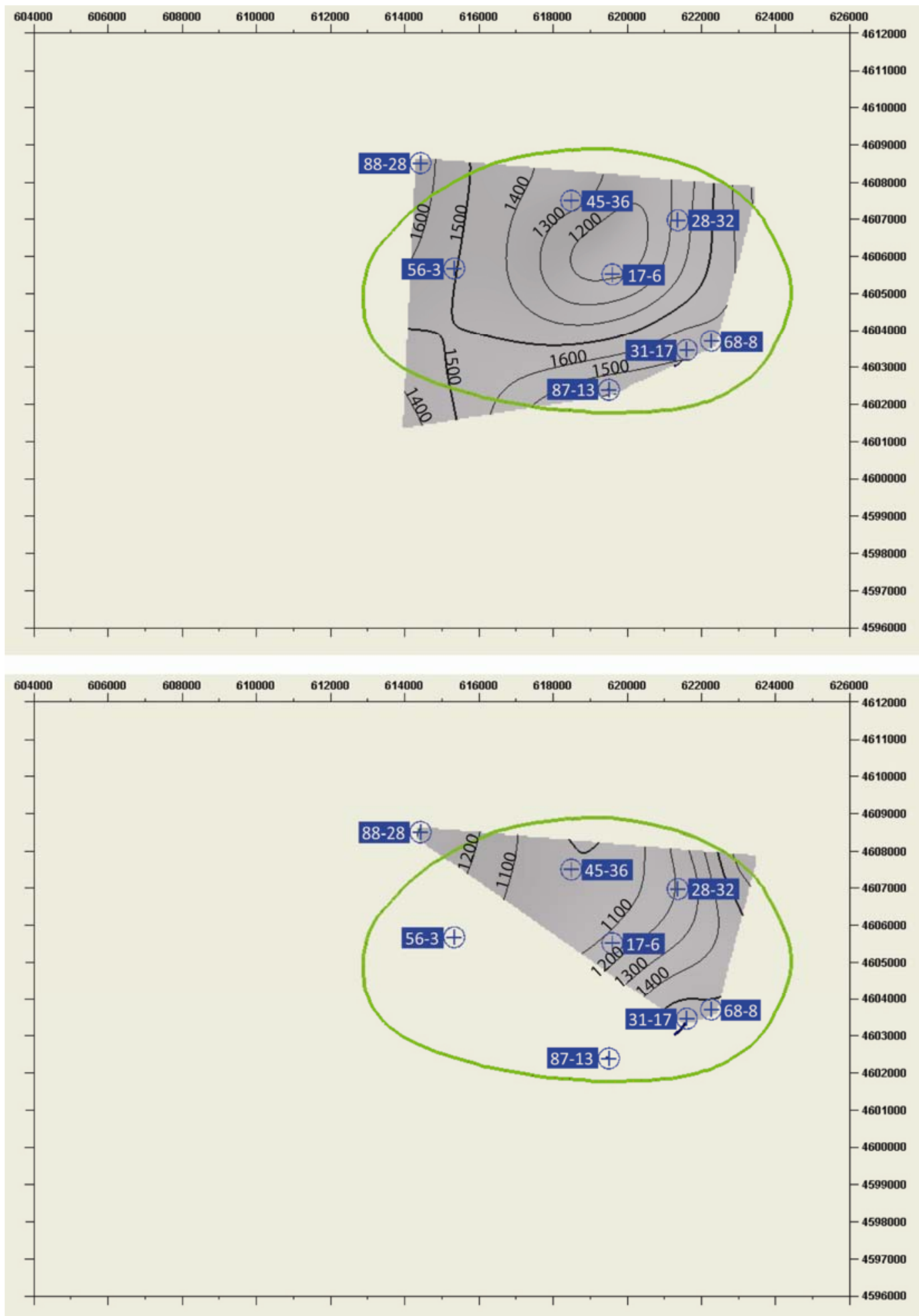

Figure 3.7c,d. (continued) 


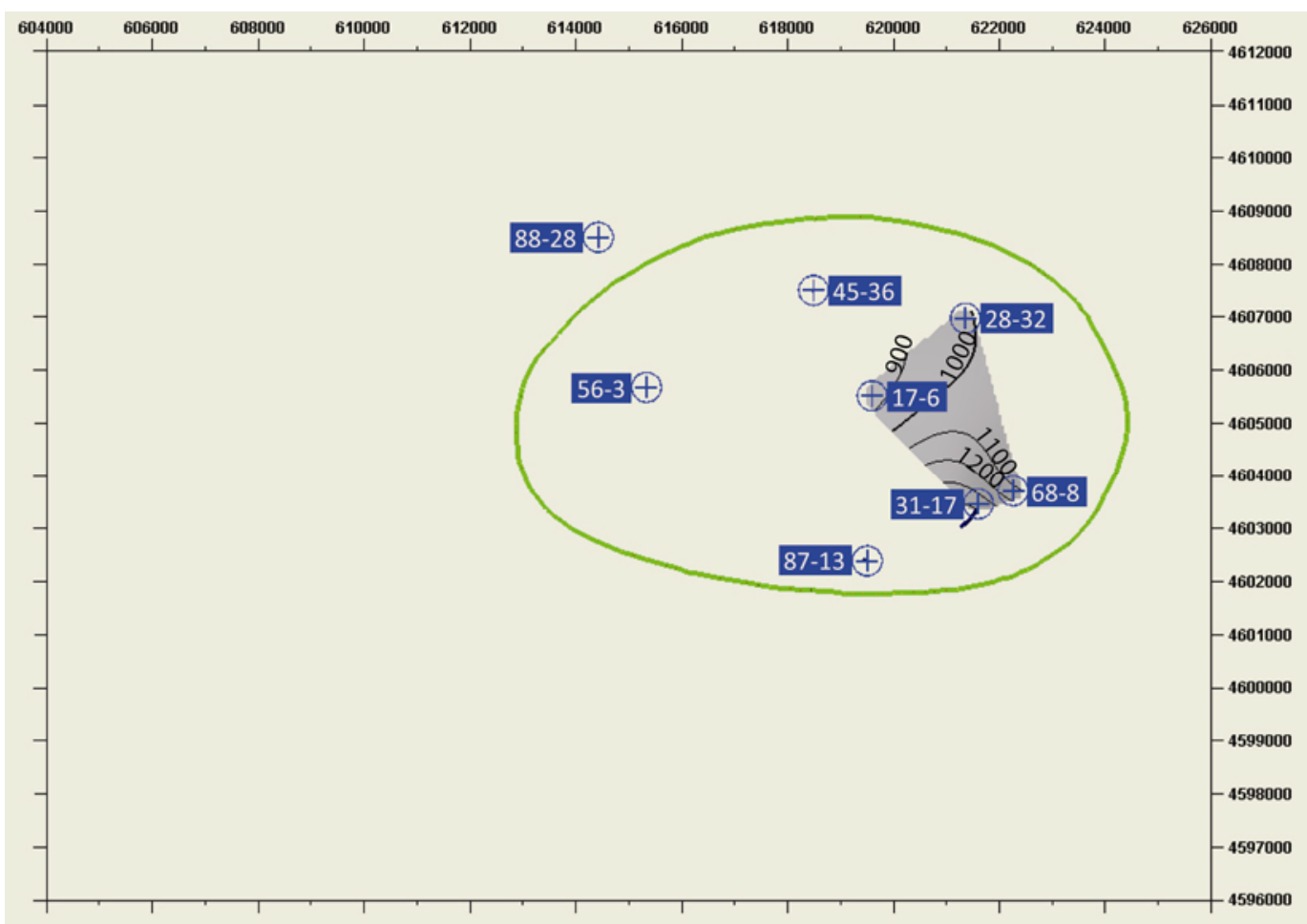

Figure 3.7e. (continued)

GMF 17-6 found on the $1012 \mathrm{~m}$ MT slice and the central temperature depression in the same area, there is no apparent relationship between this surface and the MT data.

\section{$200^{\circ} \mathrm{C}$ Temperature Surface (Fig.3.7d)}

Limited data are available for this temperature surface, and most are located on the eastern side of the volcanic rim. The surface cuts through GMF 45-36, which did not encounter $200^{\circ} \mathrm{C}$ temperatures, and therefore, the actual central depression is likely at least $100 \mathrm{~m}$ deeper than the interpolation shows. Like the cooler surfaces, temperature data for the $200^{\circ} \mathrm{C}$ surface indicates that the thermal gradient on the eastern side of the topographic rim is steeper than on the western side. 
$250^{\circ} \mathrm{C}$ Temperature Surface (Fig. 3.7e)

Data for the $250^{\circ} \mathrm{C}$ temperature surface is limited to the eastern side of the volcanic rim. The elevation difference between this surface and the $200^{\circ} \mathrm{C}$ surface is about $200-400 \mathrm{~m}$, a much larger difference than is seen between cooler temperature surfaces.

\section{$275^{\circ} \mathrm{C}$ Temperature Surface}

Only GMF $68-8$, located about $2 \mathrm{~km}$ inside of the southeastern margin of the volcanic rim, contains $275^{\circ} \mathrm{C}$ temperature data, so no interpolated surface can be generated. The elevation of this temperature zone in GMF $68-8$ is about 15 meters below sea level.

\section{Alteration Mineral Surface Model}

\section{General Observations}

The smectite, chlorite, epidote, and anhydrite surfaces are all very conformable and do not intersect one another to any significant degree. Of these, smectite is topographically highest, followed by chlorite, epidote, and anhydrite, respectively. The calcite surface is also generally conformable to the smectite, chlorite, epidote, and anhydrite surfaces, but it does project through other surfaces in some areas, as does the loosely conformable illite surface.

All of the alteration mineral surfaces define a depression around GMF17-6 and hydrothermal highs along the southern and eastern segments of the topographic ring. The highs are typically expressed as arcuate ridges. Their locations range from about $2 \mathrm{~km}$ inside to coincident with the volcanic rim. The highest point along the ridge is 
commonly located near the southeastern segment of the volcanic rim. Likewise, a high peak is commonly present near the northwest section of the ring, although it varies from about $2 \mathrm{~km}$ inside to $1 \mathrm{~km}$ outside the volcanic rim.

\section{Smectite Alteration Surface (Fig. 3.8a)}

The overall topography of the smectite surface is similar to that of the $50^{\circ} \mathrm{C}$ temperature surface. In particular, there is a ridge on the south and east sides of the volcanic ring, and a depression around GMF17-6. There is also a high near the northwest margin of the ring, roughly corresponding to the northwest peak on the $50^{\circ} \mathrm{C}$ temperature surface. However, this hydrothermal high is the northwest section of a well-defined semi-circular ridge that extends to the southern side of the volcanic ring. The ridge on the south and east side is similar to the ridge on the $50^{\circ} \mathrm{C}$ temperature surface except that the section nearest the southeastern margin of the volcanic ring lies about $2 \mathrm{~km}$ farther inside the volcanic rim. The elevation of this ridge is about 200-300 meters higher than the $50^{\circ} \mathrm{C}$ surface in this area. The depression around GMF $17-6$ matches the $50^{\circ} \mathrm{C}$ surface, but the elevation at the bottom is about 200 meters higher. Because smectite is found at shallow depths in GMF 31-17, GMF 68-8, GMF 87-13, GMF 56-3 and GMF $88-28$, the interpolated smectite surface protrudes slightly above the actual ground surface in the southeast and southwest quadrants of the topographic ring. 
Figure 3.8a-f. Petrel alteration mineral surface models in map view for the anhydrite (a), calcite (b), chlorite (c), epidote (d), illite (e), and smectite (f) surfaces. Only wells referenced in the text are shown. Wells outside the boundaries of the surfaces are either too shallow to intersect the specific surface or do not have mineralization data available. The surfaces are irregularly shaped because the surface generation feature was set to only interpolate between data points rather than extrapolate beyond data points. Contour interval is 100 meters. The X-axis shows UTM Easting location and the Y-axis shows the UTM Northing location 


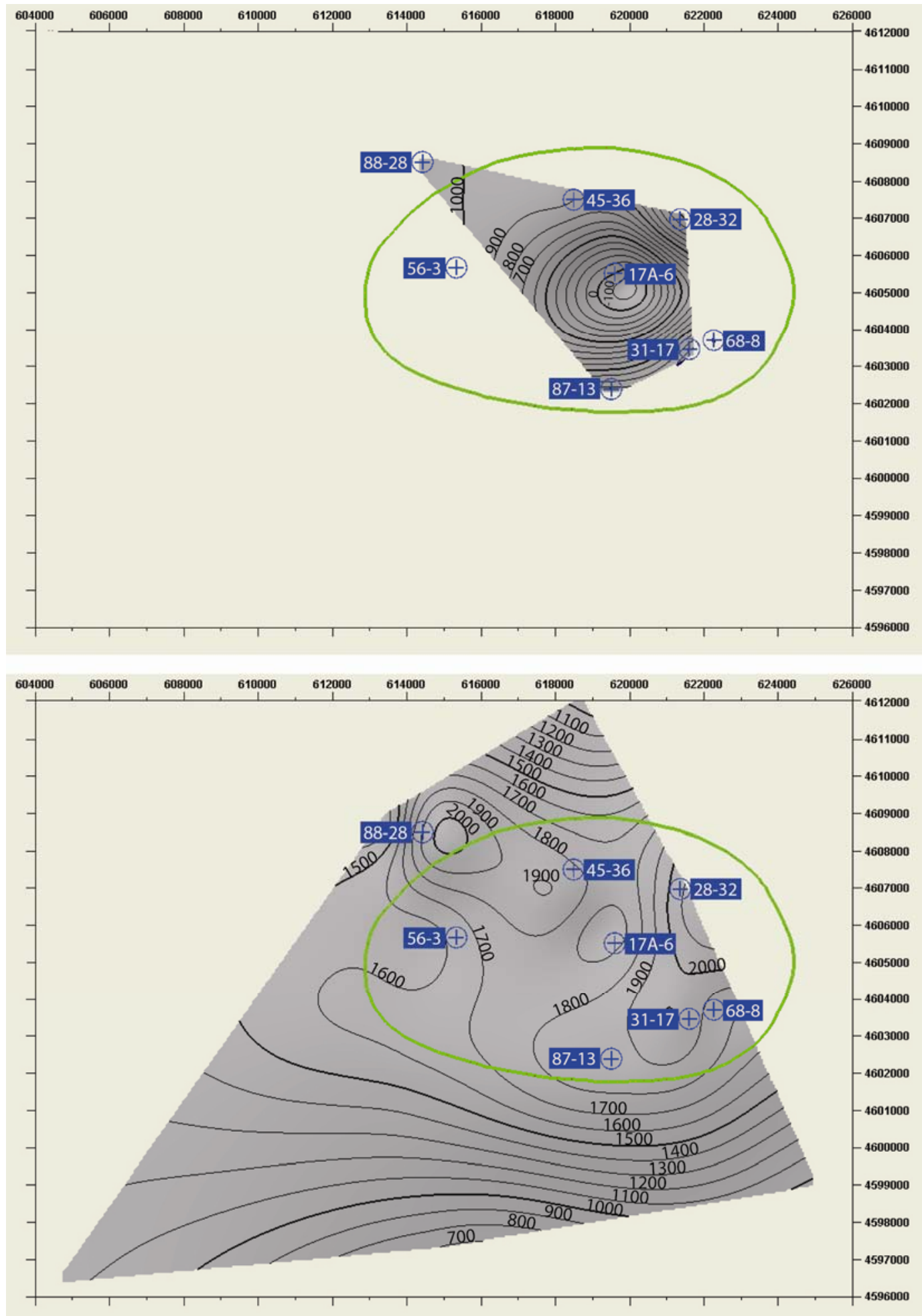




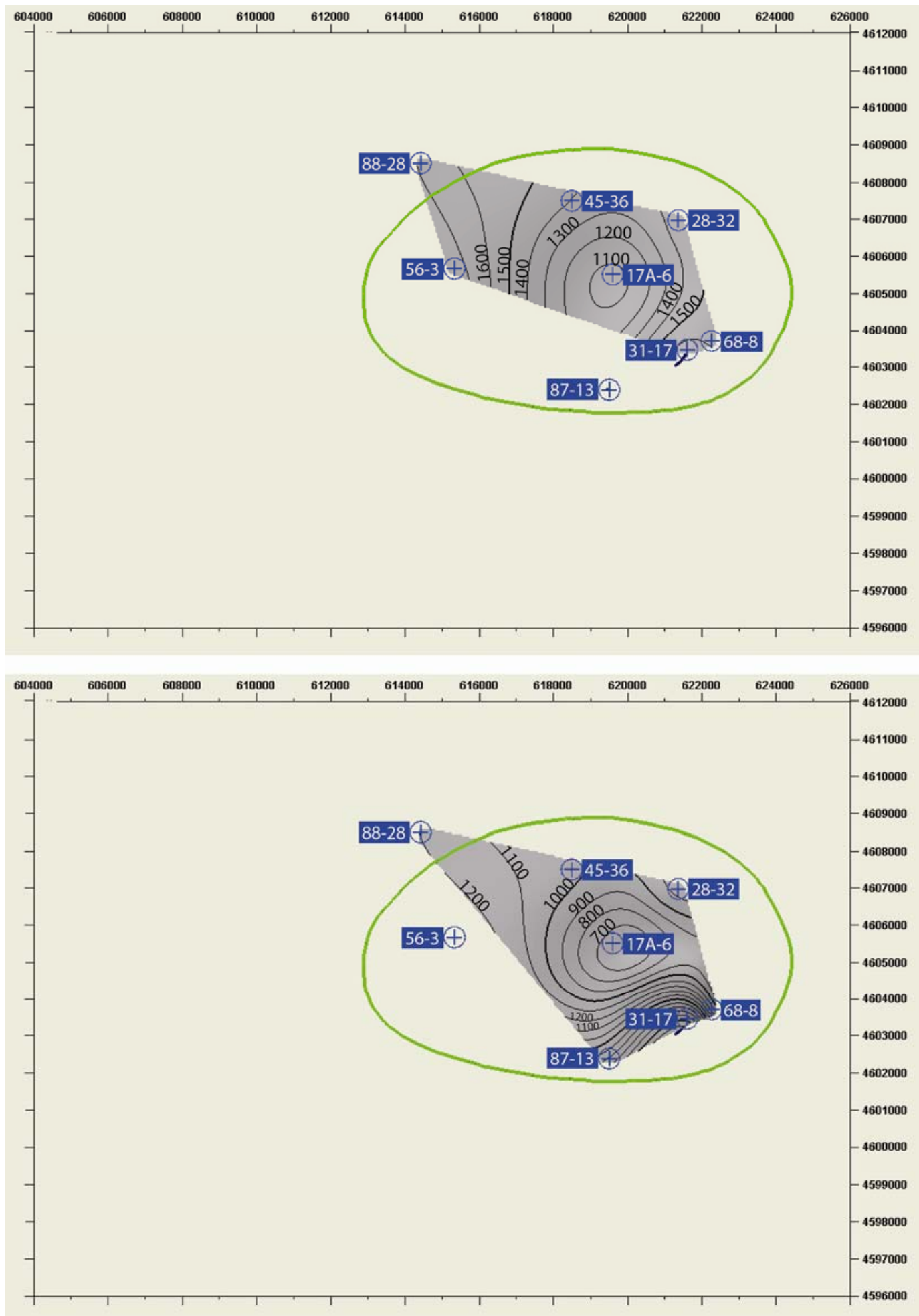

Figure 3.8c,d. (continued) 


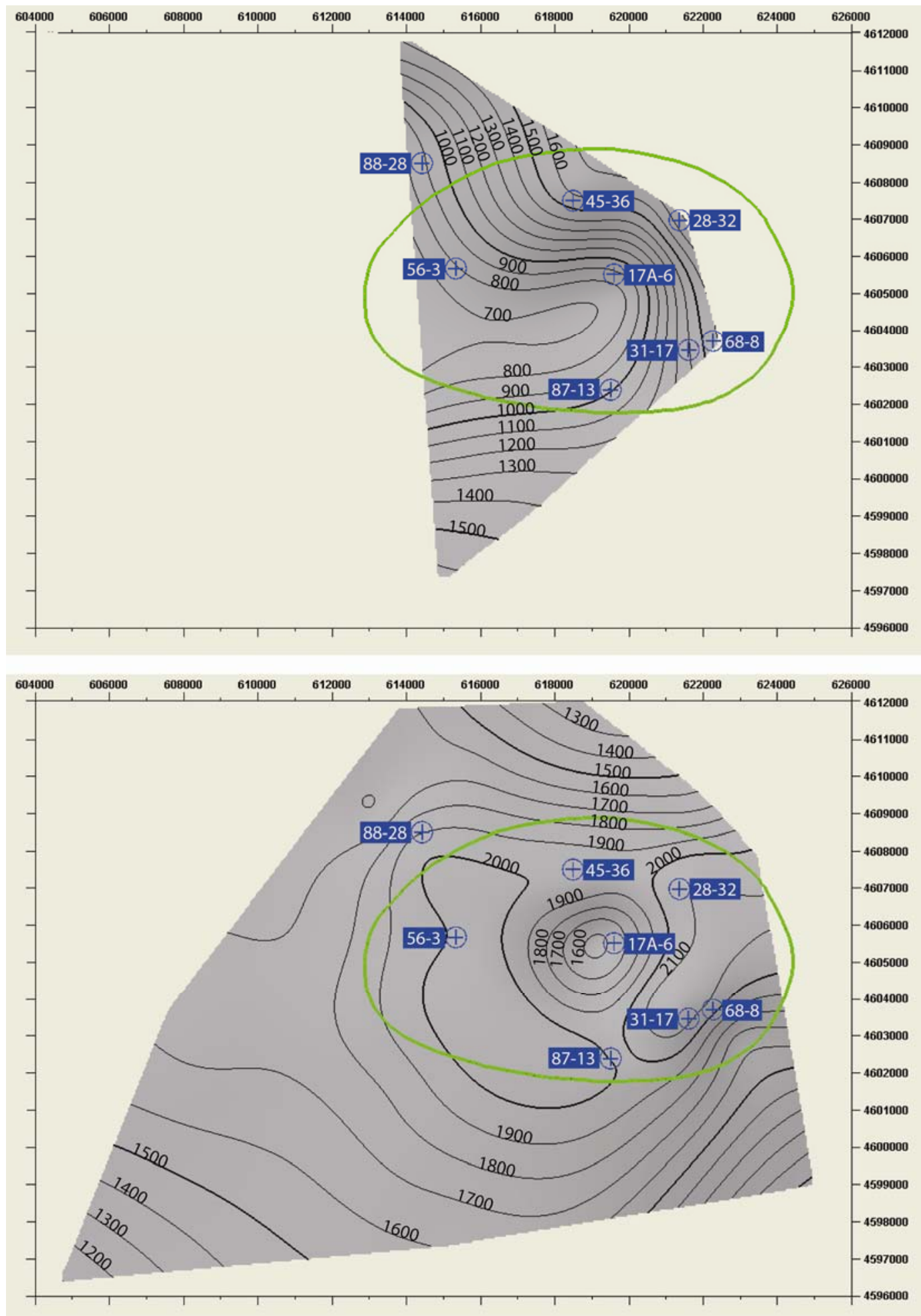

Figure 3.8e-f. (continued) 
Illite Alteration Surface (Fig. 3.8b)

The illite surface interpolation suffers from a decreased quantity of data compared to the smectite surface, especially on the west and east sides of the volcanic rim.

However, it is loosely conformable with the smectite surface.

Epidote Alteration Surface (Fig. 3.8c)

The epidote surface interpolation also suffers from limited data. The topography and shape of this surface are very similar to the shallower chlorite surface and the deeper anhydrite surface.

Chlorite Alteration Surface (Fig. 3.8d)

The chlorite surface suffers from limited data. The overall shape and topography of the chlorite surface is very conformable to the deeper epidote and anhydrite surface models.

\section{Anhydrite Alteration Surface (Fig. 3.8e)}

The topography and shape of the anhydrite surface is very similar to the shallower chlorite and epidote surfaces.

\section{Calcite Alteration Surface (Fig. 3.8f)}

The calcite surface topography is generally similar to the other surfaces, but there is less relief between the depression near GMF 17-6 and the surrounding hydrothermal highs. Because calcite is found at a shallow depth in GMF 28-32, the interpolated Calcite surface protrudes slightly above the actual ground topography in this area. 


\section{Biotite Alteration Surface}

Only three wells, all within the southeastern quadrant of the volcanic ring, contained biotite. The elevations vary considerably, so the surface is nearly vertical and is of little value other than to illustrate that secondary biotite is found at depth in MLV.

\section{Faulting Theory Calculations}

The completely logged wells reveal a composite rock column consisting of approximately $37 \%$ andesite flows and $33 \%$ dacite flows. The remaining $30 \%$ consists of basalt flows, tuffs, and sedimentary layers. Values for the angle of internal friction found in Tables 7.1 and 7.2 of Toulokian et al. (1981) range from $28^{\circ}$ to $55^{\circ}$ for andesite and $32^{\circ}$ to $41^{\circ}$ for dacite. Because the friction angle range for dacite falls entirely within the andesite range, the internal friction angle range for about $70 \%$ of the rock column can be taken as $28^{\circ}$ to $55^{\circ}$.

If the maximum principal stress, $\sigma 1$, is vertical in such a rock column, pure dipslip normal faults are predicted to dip between $59^{\circ}$ and $73^{\circ}$. Conversely, if $\sigma 2$ is vertical, a strike-slip fault with a vertical fault plane that strikes $59^{\circ}-73^{\circ}$ from the horizontal $\sigma 1$ direction is predicted. These are the most likely cases for the Medicine Lake area because there is little regional evidence of thrust or reverse faulting. Indeed, normal and strike-slip faults are seen throughout the region, which suggests that $\sigma 1$ and $\sigma 2$ are approximately equal and locally one or the other is vertically oriented. The observed fault pattern thus implies that $\sigma 3$ is uniformly horizontal across the region.

Much of the remaining $30 \%$ of the rock column is tuff. The angle of internal friction for tuff ranges from $10^{\circ}$ to $22^{\circ}$ (Toulokian et al., 1981), which should yield a normal fault that dips $50-56^{\circ}$, the shallowest theoretical dip of any rock type found in 
these wells. Because much of the remainder of the composite rock column consists of tuffs and soil layers that contribute to shallower normal fault dips, the total composite rock column is likely to contain faults with dips closer to the lower end of the $59^{\circ}$ to $73^{\circ}$ range. 


\title{
CHAPTER 4
}

\section{INTERPRETATION AND DISCUSSION}

\author{
$\underline{\text { Introduction }}$
}

Medicine Lake Volcano is characterized by a broad shield crowned with a topographic ring surrounding a central basin. There are two processes that could contribute to the relief observed between the floor of the summit basin and the top of the topographic ring: subsidence of the central floor and constructional volcanism around the perimeter. These processes are not mutually exclusive and may well work in concert to generate the topography at the summit of MLV. There are two possible mechanisms that may drive these processes. The first mechanism involves regional tectonics. There are a number of ways in which tectonic processes can generate topographic relief. However, as discussed in Chapter 1, Medicine Lake Volcano is located in a geologic setting where just two are plausible: extension resulting in an orthogonal rift and strike-slip displacement creating a pull-apart basin. The second mechanism is localized volcanism contributing to subsidence as a magma chamber is deflated. Both mechanisms could result in constructional volcanism.

Determining which tectonic and/or volcanic mechanisms are occurring at MLV forms the basis for the hypotheses proposed in Chapter 1: 1) orthogonal rift basin, 2) orthogonal rift dominated by a caldera, 3) pull-apart basin, 4) pull-apart basin dominated by a caldera, and 5) simple collapse caldera. 


\section{$\underline{\text { Tectonic Mechanisms }}$}

Medicine Lake Volcano is located in a tectonically active area and is surrounded by numerous fault zones (Fig. 2.6). The USGS Quaternary Fault and Fold Database (FFDB) does not contain information for faults closer than $8.5 \mathrm{~km}$ to MLV, nor does it contain information other than location data for some fault zones. However, it does provide insight into the tectonic setting in the area around MLV even if it does not provide direct clues to the origin of the topographic rim.

There are three major fault zones found in the FFDB that are likely to be related to or interact with other mapped faults and fissures in and around MLV. The Gillem-Big Crack Fault System lies to the north and the Mayfield Fault Zone and the unnamed faults of the Hambone-Dana area are south of MLV (Fig. 4.1).

The Gillem-Big Crack Fault System dips east at an estimated $50^{\circ}-70^{\circ}$ and accommodates normal slip (Bryant, 2000a). The Mayfield Fault Zone is not well understood, but shows normal displacement across steep west-dipping faults (Bryant, 1995). Only location data are available for the Hambone-Dana faults. Additionally, the McArthur and Hat Creek Fault Zones are located just south of and on strike with the Mayfield and Hambone Dana Fault Zones, respectively, and both have been interpreted to be normal with possible components of dextral shear (Fig. 4.1) (Sawyer, 1995a; b).

The mapped faults and lineaments west of, and tangential to, the summit basin (California DONR, 1958; USGS, 1971; Union, 1975), have been interpreted and termed the Little Glass Mountain Fault Zone (Fig. 4.2) (Nordquist and Thompson, 1990). 
Figure 4.1. Shaded relief map highlighting major regional faults that may play a role in the development and location of Medicine Lake Volcano. 


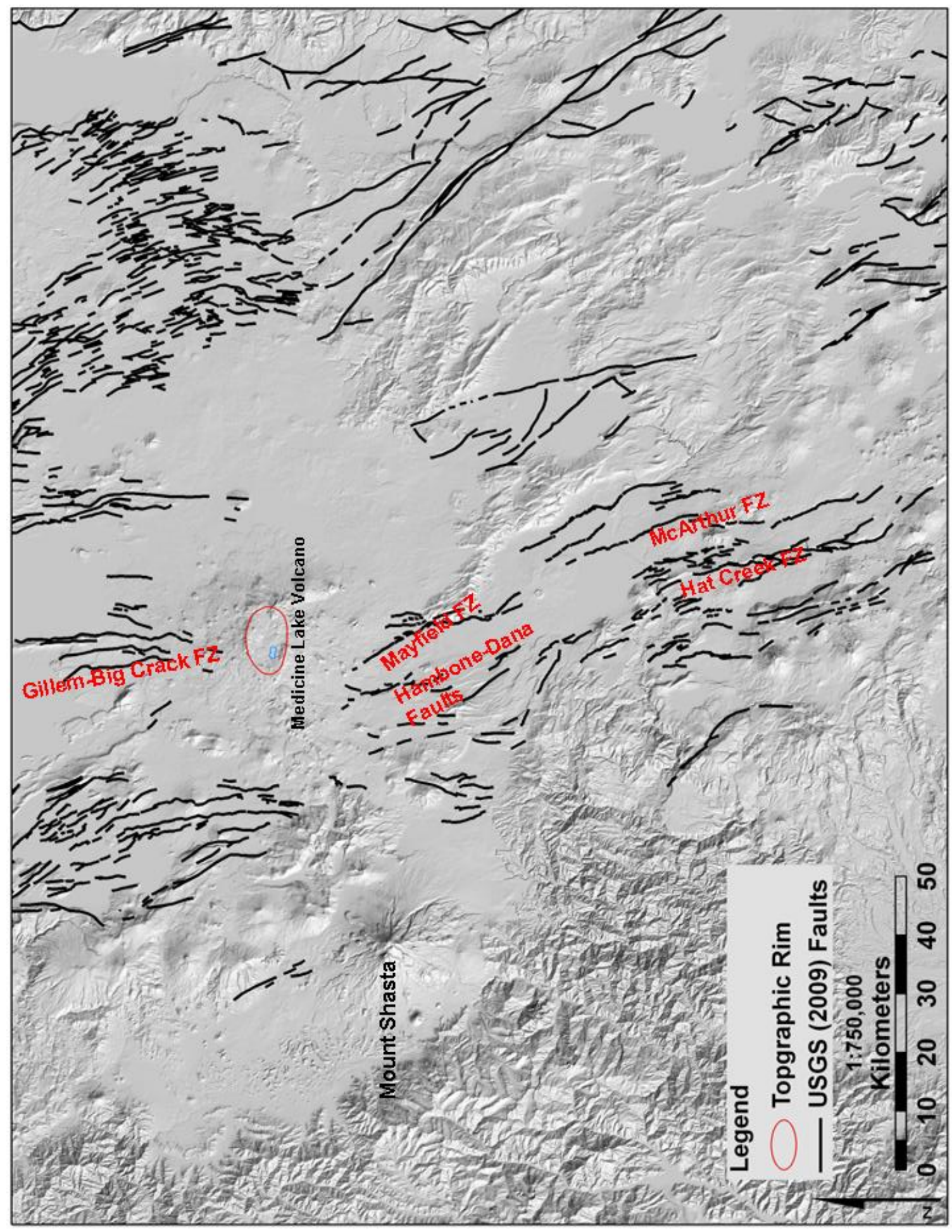


Figure 4.2. Shaded relief map showing possible interactions of the Little Glass Mountain Fault Zone and other local faults and lineaments with regional fault zones at Medicine Lake Volcano.

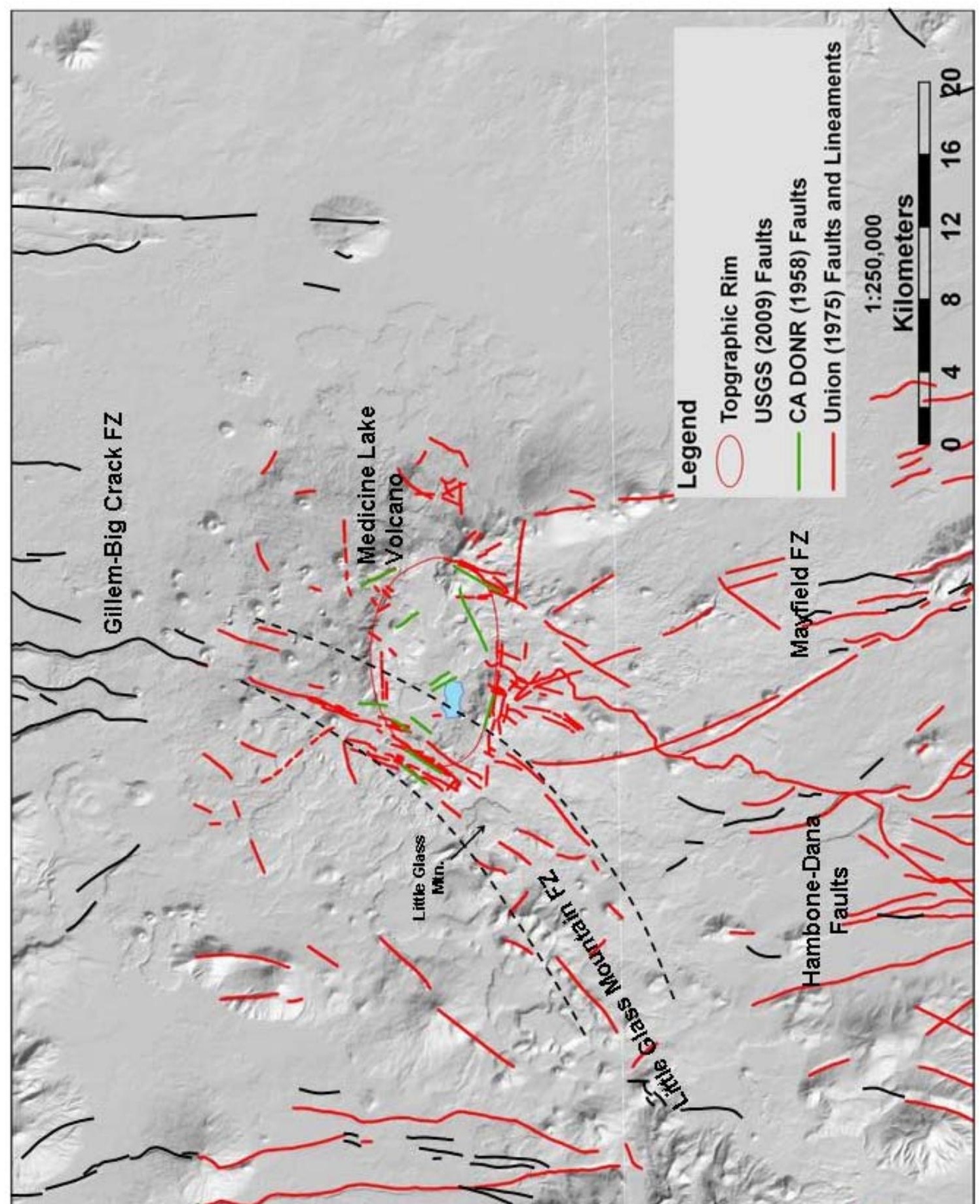


Tensional ground cracks (Nordquist and Thompson, 1990) and some mapped normal faulting suggest that this zone extends north and south of MLV and is associated with Basin and Range crustal stretching. Some of the mapped features of the Little Glass Mountain Fault Zone may be related to the volcanic highland stretching between Mount Shasta and Medicine Lake Volcano. This highland encompasses a number of volcanic vents that delineate a zone of crustal weakness where magmas are able to ascend to the surface (Fig. 4.3) (Donnelly-Nolan et al., 2008). The strike of the Mayfield and Hambone-Dana faults can reasonably be projected into the Little Glass Mountain Fault Zone. These faults are in turn easily projected into the Gillem-Big Crack Fault Zone. Indeed, these Little Glass Mountain faults seem to be part of a through-going fault zone, roughly tangential to the ring at the western margin that could link the Mayfield and/or Hambone-Dana faults with the Gillem-Big Crack faults.

As discussed in Chapter 1, MLV formed above the extensional Modoc Plateau (Lutz et al., 2000; Hildreth, 2007). Structural and other geologic evidence indicates that the region has continued to be subjected to east-west extension. For example, 10 meters of vertical offset is present across a fault that crosscuts the $12.5 \mathrm{ka}$ Giant Crater lava (Donnelly-Nolan et al., 2008). Seismic and leveling data show that this extension and faulting is ongoing (Dzurisin, 1991). Regional fault zones (Fig. 4.1) tend to strike northward, exhibit normal slip, and may show up to a few hundred meters of displacement (Dzurisisn, 1991). Open ground cracks striking NNE to NNW with E-W opening directions are common on the lower flanks and the upper NW flank of the volcano (Donnelly-Nolan, 1990; Donnelly-Nolan et al., 2008). These cracks and 
Figure 4.3. Shaded relief map showing major tectonic features in the Medicine Lake Volcano area of the southern Cascades Arc. The blue arrows indicate the approximate extension direction across the volcano. After Donnelly-Nolan et al. (2008). 


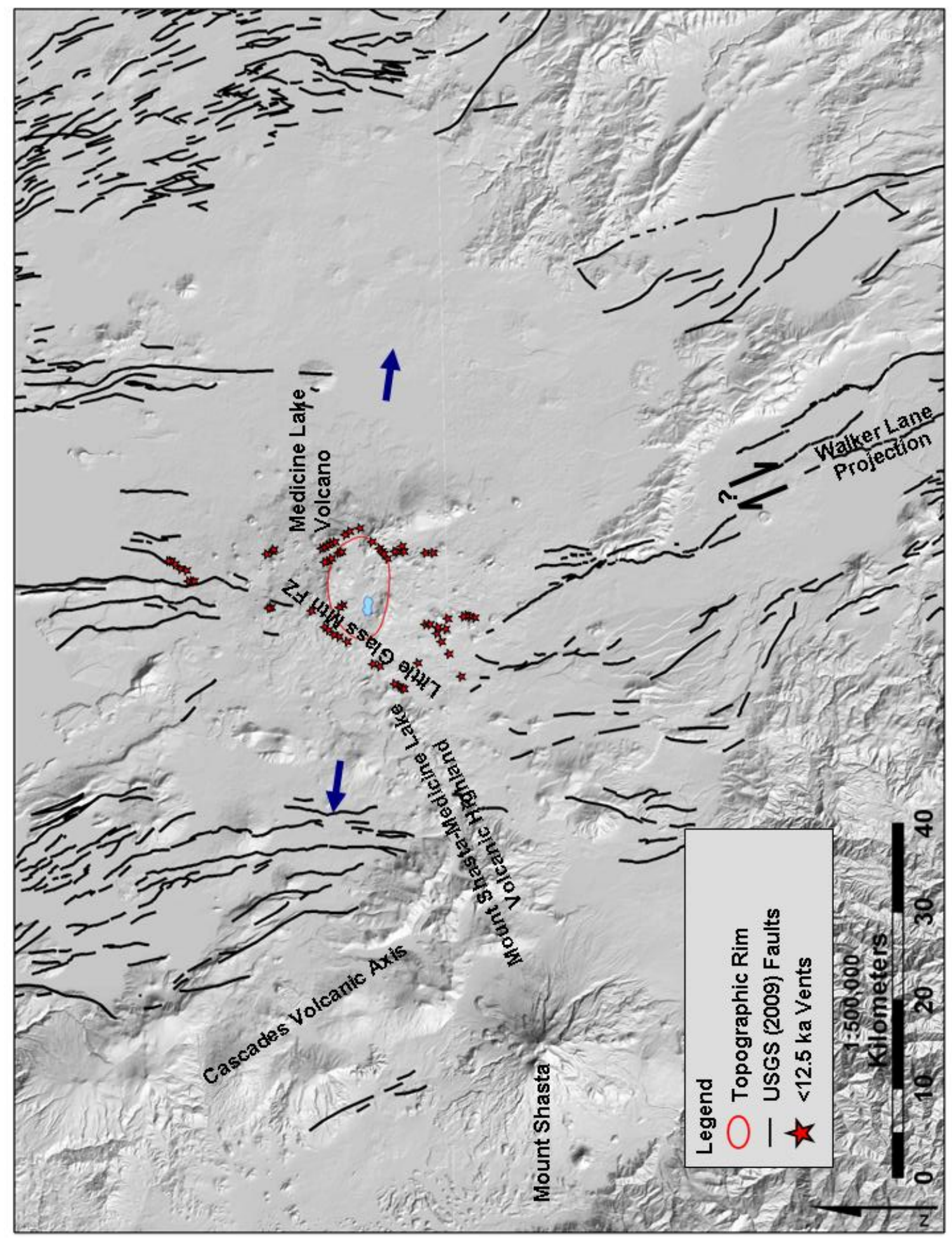


volcanic vent alignments that are typically parallel or subparallel to regional normal faults, suggest they are related to regional extension (Anderson, 1941; Donnelly-Nolan, 1990; Donnelly-Nolan et al., 1990, 2008).

The dextral faults of Walker Lane define a trend roughly aligned with the volcano when they are projected farther to the northwest (Figs. 1.4; 1.5). Glazner et al. (2002) estimate that cumulative dextral slip across the Mojave Desert region (Fig. 1.4) is roughly 45-60 km. Faulds et al. (2005) estimated dextral offset of 10-15 km across the Warm Springs Valley fault and the central section of the Honey Lake fault, both of which are about $190 \mathrm{~km} \mathrm{SE}$ of MLV (Fig. 1.5). If the decrease in dextral shear along the Walker Lane is linear, it should die out between $60 \mathrm{~km}$ southeast and $130 \mathrm{~km}$ northwest of MLV. Therefore it is plausible that dextral shear from Walker Lane is present at MLV.

During his field study in 2006, Nemčok interpreted Sites 5 and 6 to define a small pull-apart basin. Such an interpretation supports the existence of significant strike-slip shear around MLV.

Striae data from both field and oriented core measurements (Tables 3.3 and 3.4) frequently exhibit slip senses with dextral components and unoriented core fractures (Fig. 3.1) often reveal strike- and oblique- slip striae in addition to those with dip slip. The existence of striae exhibiting strike slip and oblique slip may indicate northwest propagation of Walker Lane dextral shear, especially since dextral components are more common than sinistral components. However, the strike-slip striae may also be the result of accommodation of E-W extension across local fault segments that deviate from N-S orientations. Despite the strong possibility that Walker Lane dextral shear is present, it is clear that east-west extension dominates the Medicine Lake area. 


\section{Orthogonal Rift Hypotheses}

Medicine Lake Volcano is located in a zone of east-west extension that contains numerous extension-related basins. However, a basin in an extensional zone need not have formed due to rifting. The topography at the summit of MLV argues against such a hypothesis. Most of the valleys within the Basin and Range are half grabens that are much longer than they are wide. However, the depression atop MLV only extends about $7 \mathrm{~km} \mathrm{~N}-\mathrm{S}$ while the $\mathrm{E}-\mathrm{W}$ dimension is about $12 \mathrm{~km}$.

A rift basin of this geometry would also require considerable strike-slip faulting across the north and south margins to accommodate the extension. Such transform motion should result in more strike- and oblique-slip striae within the ring compared to outside the ring which contradicts the observations (Fig. 3.1).

The orientation of the $\mathrm{P}$ and $\mathrm{T}$ axes (Figs. $3.4 ; 3.5$ ) within the topographic ring are not consistent with a rift basin formed by E-W extension. In such a basin, the $\mathrm{T}$ axes should be oriented E-W. However, field sites 14, 15, and 18 and samples W2-2 (GMF 28-32) and W4-2 (GMF 87-13) exhibit T axes roughly perpendicular to the topographic ring (Fig. 4.4) at their specific locations. The reverse shear found in sample W4-1 is also inconsistent with an extensional basin, although it appears to be anomalous and may be the result of fracturing due to a local intrusion. Only sample W2-1 exhibits T axes aligned E-W. The T axes for samples outside the topographic ring are roughly oriented $\mathrm{E}-\mathrm{W}$, which strengthens the premise that MLV resides in an extensional zone but is inconclusive with respect to the origin of the basin. 
Figure 4.4. Map depicting trends of extension and contraction calculated from plots of $P$ and $\mathrm{T}$ axes of 10 intervals of paleomagnetically oriented core and three field locations. Relative length of each arrow corresponds to the plunge of the trend. 


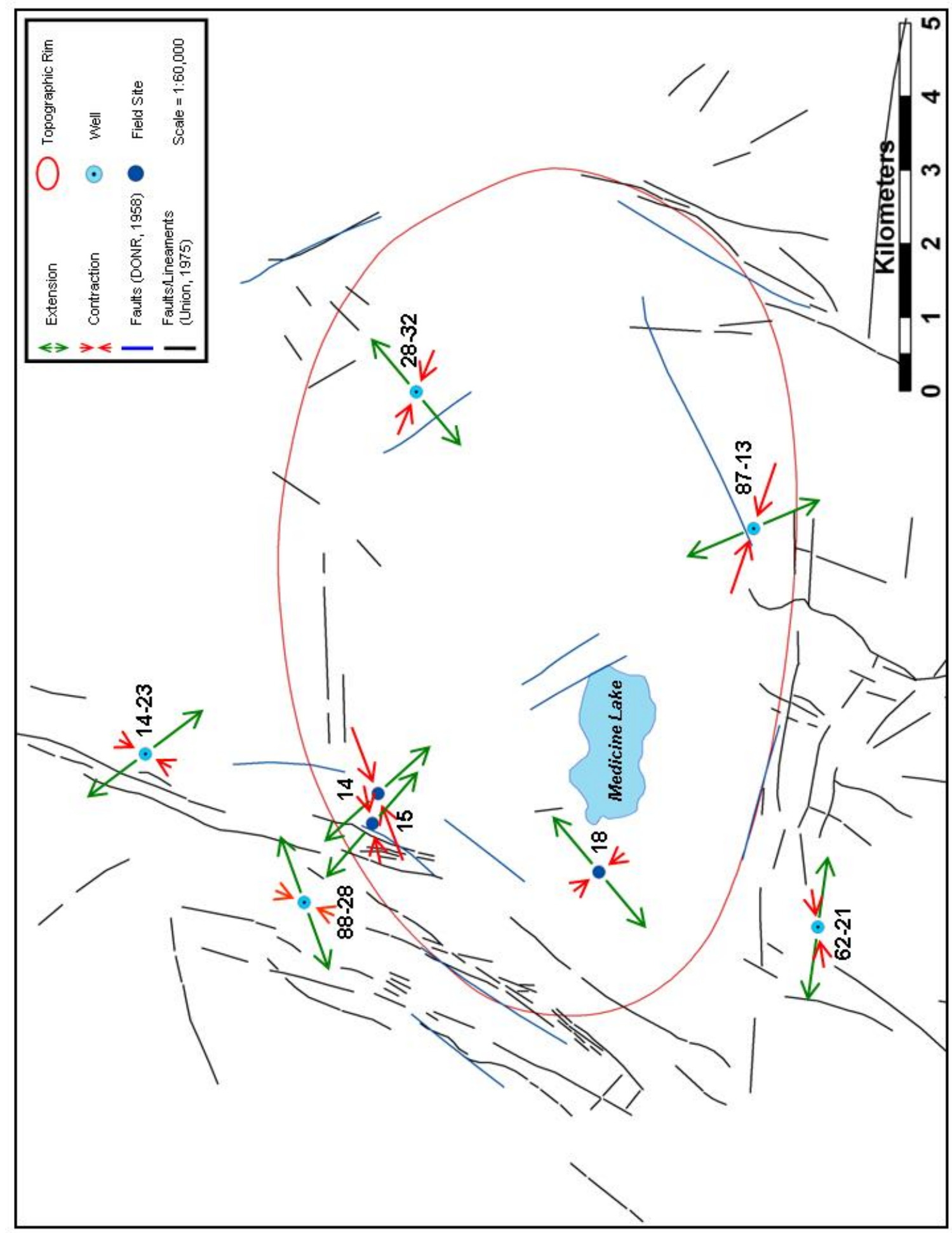


Whereas east-west extension is certainly present around Medicine Lake Volcano, there is little evidence to support a hypothesis relating to any type of rifting with or without an associated caldera as being the sole mechanism responsible for the summit structures. However, the common north-south alignment of vents suggests that extension has influenced the growth of Medicine Lake Volcano.

\section{Pull-Apart Basin Hypotheses}

If the enclosed summit basin is the result of regional faulting, the geometry fits a pull-apart basin hypothesis better. However, the shape of the basin lacks the angularity expected in a pull apart. The pull-apart hypothesis is based on the idea that the Hambone-Dana area or Mayfield faults from the south connect with the Little Glass Mountain Fault Zone and then step right to the eastern margin of the topographic ring and continue to the north. The E-W faults on the northern and southern margins of the topographic ring would constitute the adjoining normal faults (Fig. 4.5).

The mapped fault patterns reveal several problems with this hypothesis. The first is the fact that Little Glass Mountain Fault Zone, which would be expected to terminate near the northwest section of the topographic ring, continues toward the Gillem-Big Crack faults to the north. The second problem is that there are few mapped faults that could correspond to the hypothetical dextral faults on the east side. It is possible that the required faults are present and simply buried under young lava flows as discussed by Dzurisin (1991). This possibility is even greater near the northeast margin of the topographic rim because it is covered by the 890 year old Glass Mountain rhyolite flow (Donnelly-Nolan et al., 2007). However, even if they are locally concealed, it is difficult to project them into any other fault system to the north that might accommodate Walker 
Figure 4.5. Map depicting the hypothetical pull-apart basin, related faults, and the 412 m.a.s.l. MT slice at Medicine Lake Volcano. 


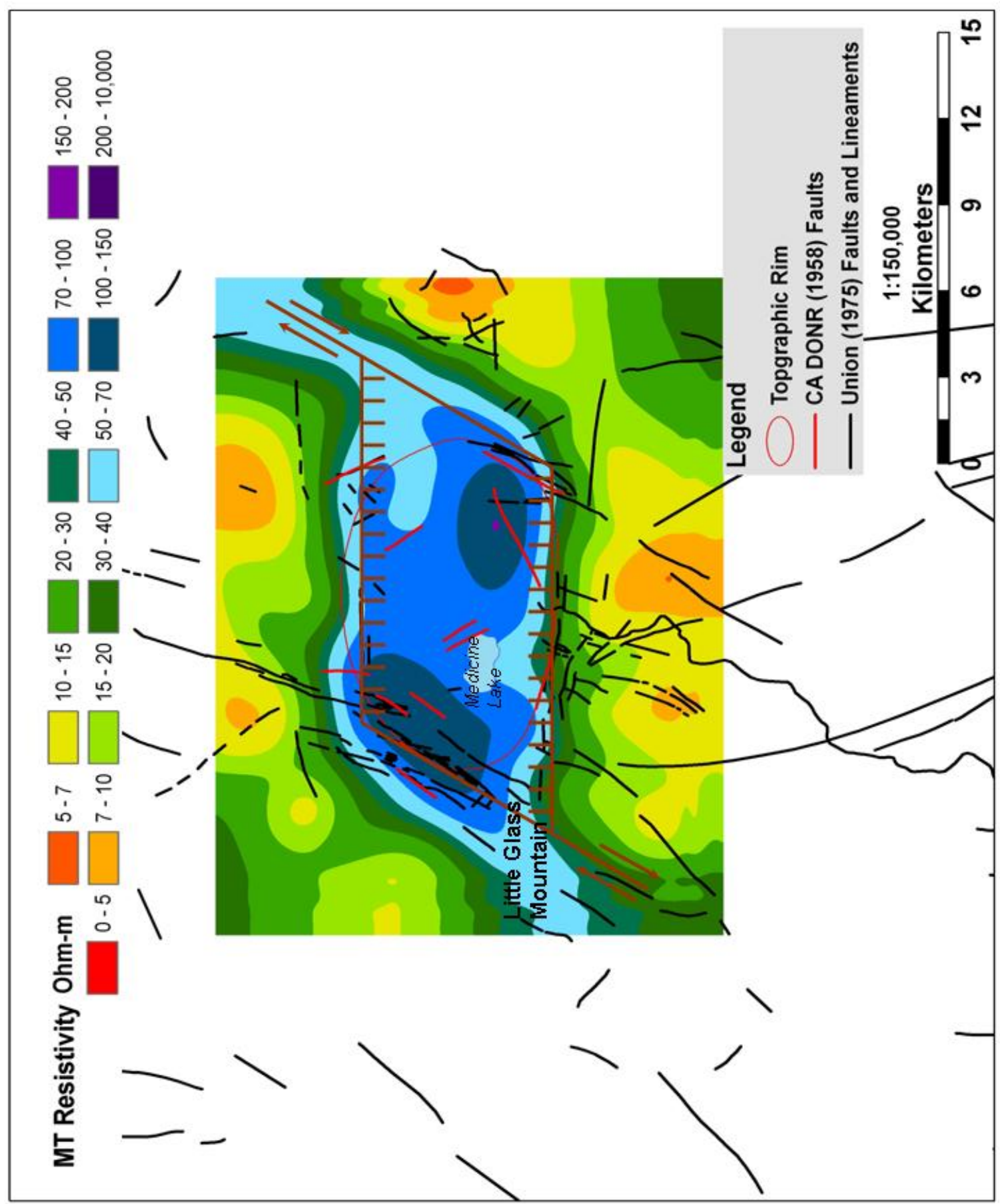


Lane dextral shear. Finally, the northeast strike of the hypothetical bounding faults on the east and west sides of the topographic ring are roughly orthogonal to the projection of Walker Lane.

The $\mathrm{P}$ and $\mathrm{T}$ axes within the topographic ring do not suggest that the summit basin is a pull apart (Fig. 4.4). In such a basin, the T axes should be oriented roughly N-S. Instead, T axes are roughly radial to the ring as discussed previously. Only the $\mathrm{T}$ axis of W4-2 (GMF 87-13) is oriented roughly N-S, but at its location on the south side of the rim the $\mathrm{T}$ axis is also approximately radial to the topographic ring. The orientation of the $\mathrm{P}$ and $\mathrm{T}$ axes outside the ring suggest $\mathrm{E}-\mathrm{W}$ extension is dominant.

The sigmoid patterns on the MT maps below the 1012 m.a.s.l. slice superficially resemble a pull-apart basin (Fig. 3.6d-g). The high resistivity zones that extend away from the topographic ring to the northeast and southwest could represent the strike-slip bounding faults of a pull apart. Such faults would likely conduct hot, mineral-enriched waters away from the central MLV summit. However, this should make these zones conductive rather than highly resistive. If the bounding faults were no longer active, it is conceivable they could become sealed through mineralization and exhibit high resistivity. But such an idea is not consistent with the young age of MLV and the requirement for recent if not on-going strike-slip deformation. Cummings and Mackie (2007) report that the SW and NE contour diversions that change the overall patterns from elliptical to sigmoidal on the slices deeper than 1012 m.a.s.l. correlate better to regional structures than to the rim structure, but they also note that the southwest diversion could be due to a gap in the MT data. In any event, with few exceptions, there are few mapped fault traces or lineaments that align with these diversions (Fig. 4.5) and those that do may be related 
to the Mount Shasta-MLV volcanic highland (Fig. 4.3). Additionally, if the diversions were related to strike-slip bounding faults, they should be present as low resistivity zones on the shallower slices.

Although Walker Lane dextral shear appears to have propagated into the MLV area, most of the data do not suggest that it has created a pull apart that governs the topography at the summit of MLV. Therefore, it is reasonable to conclude that the summit depression was formed by local volcanic mechanisms.

\section{$\underline{\text { Volcanic Mechanisms }}$}

\section{Caldera Collapse Hypothesis}

The smoothly elliptical topographic ring that crowns Medicine Lake Volcano dovetails nicely with caldera collapse whereas it is problematic for the tectonically controlled hypotheses.

The simplest explanation is that the summit depression formed by co-eruptive collapse. The ring faults at the circumference of most collapse calderas will dip steeply or vertically with vertical displacements on the order of several hundred meters to a few kilometers (Gudmundsson and Nilsen, 2006). The apparent displacement at MLV based on the topographic relief is about 200-375 meters, but this does not account for erosion of the topographic rim, caldera infilling by volcanic ejecta and sedimentation, or constructional volcanism building up the rim. The elliptical geometry of a caldera can be related to the collapse of an elongated magma chamber or to post-caldera extension (Acocella, et al., 2004). The relatively young age ( $<500 \mathrm{ka})$ of MLV suggests that the effect of regional extension on the shape of the caldera is minimal. 
Mapped faults (CA DONR, 1958; USGS, 1971; Union, 1975) are tangential to the topographic rim in many areas, lending support to a collapse hypothesis. Anderson (1941) noted that while most faults at MLV strike N-S, the strikes of some faults roughly coincide with the topographic ring. Hausback (1984) states that the distribution of vents along an elliptical arc around the MLV summit are evidence that a ring-fracturing event did occur, regardless of whether it contributed to measureable collapse.

Whereas the radial pattern of extension exhibited by the $\mathrm{T}$ axes in oriented core samples and field site data from within the topographic ring (Fig. 4.1a) is inconsistent with a rift or pull-apart basin, it is most consistent with displacement across arcuate ring faults that approximately coincide with the topographic rim. Slip across a ring fault system may also explain the higher proportion of dip-slip striae found in the unoriented core from wells within the topographic ring.

In general, the temperature and alteration mineral models (Figs. 3.7a-e, 3.8a-g) appear to be consistent with caldera collapse. The premise behind the models is that heated fluids will migrate toward the surface through fault and fracture zones. The result will be high temperatures at shallow depths and the precipitation of hydrothermal minerals in the fault and fracture zones. The models show these as ridges on a 3dimensional surface. Ridges in the temperature and alteration models generally coincide with the surface trace of the topographic rim, revealing an apparent relationship in size and geometry with the surface geometry. The ridges on vertically stacked surfaces tend to be horizontally aligned, suggesting steeply dipping faults.

However, the value of these models is limited in two ways. First, feature resolution is low because well density is low. Second, intrusions are, and a magma 
chamber may be, present beneath the volcano (see Chapter 1). These heat sources are distributed variably within the volume of the volcano and may vary widely in temperature. Therefore, localized conductive heating may modify a shallow temperature perturbation caused by the upflow of heated fluids or may be the primary cause of the high-temperature anomaly. Because fault and fracture zones also conduct magma, ring dikes are likely present and their heating would mimic the patterns caused by heated fluids. So, regardless of the cause of the ridges, the models do contain a measure of validity.

The only known ash-flow tuff from MLV was produced by a pyroclastic eruption at about $180 \mathrm{ka}$ that is present in all areas of the volcano and is commonly interpreted to have contributed to caldera formation (Donnelly-Nolan et al., 2007). The largest pumice lumps and lithic inclusions in the ash-flow tuff are found in outcrop within the northwest quadrant of the caldera, suggesting the eruption was near the summit (Donnelly-Nolan et al., 2008). However, the volume of this tuff, estimated at about $2 \mathrm{~km}^{3}$ (Donnelly-Nolan, 1983 as cited in Hausback, 1984), would alone contribute only about 8 meters of coeruption subsidence within the $264 \mathrm{~km}^{2}$ area of the topographic ring. The small volume of tuff does not support caldera collapse from this event as the sole mechanism responsible for the summit depression (Hausback, 1984; Joseph Moore, Energy and Geoscience Institute, personal communication).

Magma chamber deflation from flank eruptions could also cause caldera collapse. A contribution to Wood and Kienle (1990) by Julie Donnelly-Nolan states that the caldera probably formed by repeated subsidence as fluid lavas flowed down the shield from summit vents rather than due to the eruption of the ash-flow tuff. 
The pyroclastic eruption that emplaced the ash-flow tuff came relatively late in the life of MLV. The oldest K-Ar age for flows interpreted to be from MLV reported by Donnelly-Nolan and Lanphere (2005) is $732 \pm 22 \mathrm{ka}$. Their data using 40Ar-39Ar methods reveals an isochron age of $444 \pm 76 \mathrm{ka}$ for the oldest MLV rocks. However, Donnelly-Nolan et al. (2008) assigned a maximum age of $500 \mathrm{ka}$ to the initiation of the MLV volcanic focus. Donnelly-Nolan et al. (2008) divide the eruptive history of MLV into five time periods based on ages, stratigraphic relationships, composition, and morphology (Fig 4.6). These time periods are referenced in the following paragraphs.

The Period 1 ( $<500$ to $300 \mathrm{ka}$ ) and 2 (300 to $\sim 180 \mathrm{ka}$ ) eruptions emplaced lavas ranging from rhyolite to basalt and undoubtedly began to construct the MLV shield atop the older Modoc Plateau lavas. Most of the lava flows were on the western flank of MLV and could have initiated caldera formation through deflation of a central magma chamber. However, stratigraphic correlation of the ash-flow tuff from coreholes both inside and outside of the caldera indicates that the center of the basin has subsided approximately 240-440 meters relative to the margins (Donnelly-Nolan, 2008). The presence of the ashflow tuff around the margins of the caldera and near the center of the down-dropped caldera floor suggests that the center of the floor was at roughly the same elevation as the margins at the time of the eruption. Therefore, if flank eruptions preceding the eruption of the ash-flow tuff contributed to caldera subsidence, their role was probably minor. The eruption of the ash-flow tuff itself contributed only a small amount of co-eruptive subsidence. However, the eruption probably initiated ring faults that were approximately coincident with the modern topographic rim. 

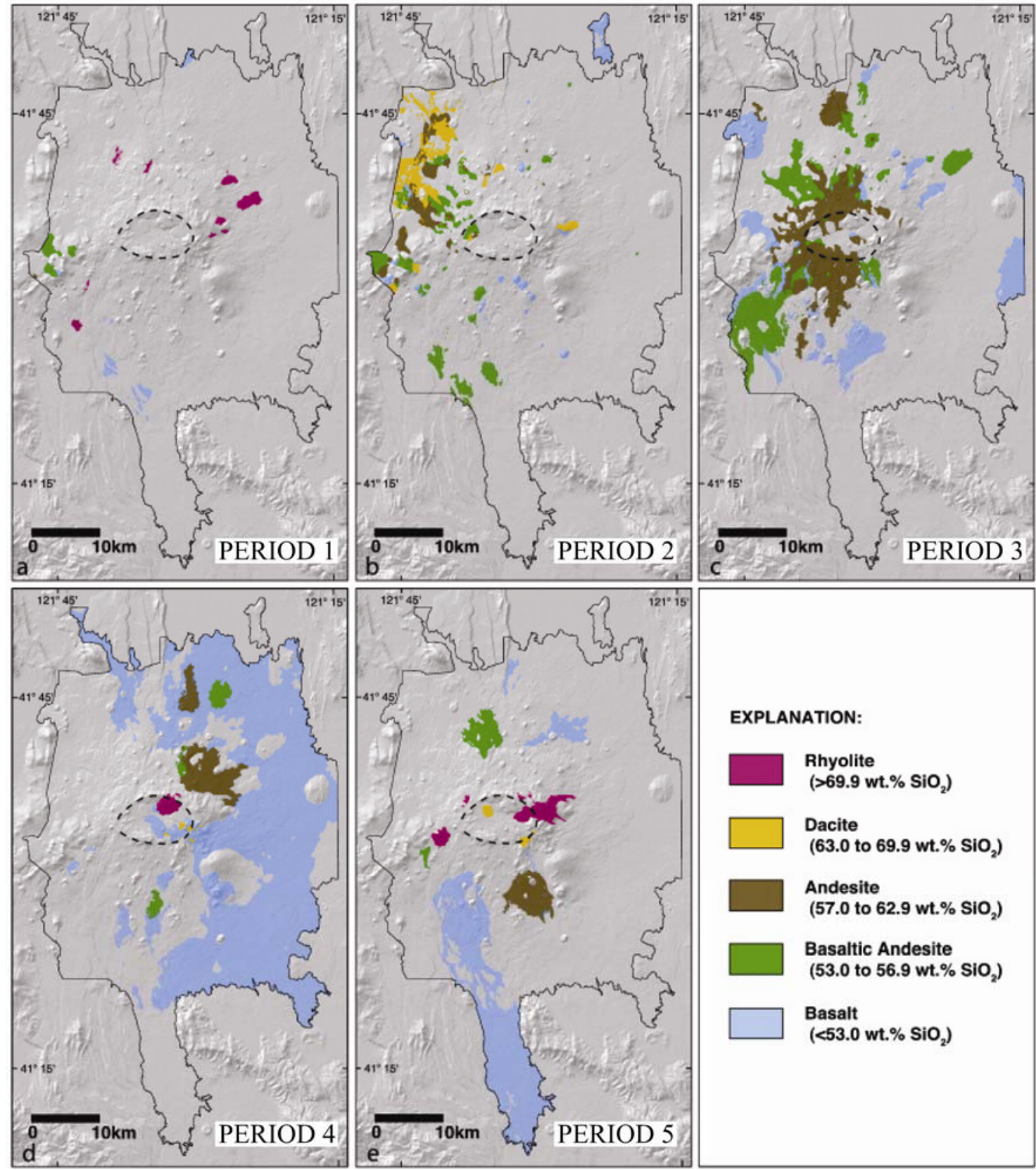

EXPLANATION:

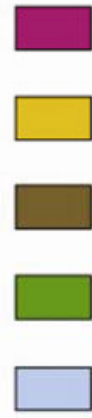

Rhyolite

(>69.9 wt.\% $\mathrm{SiO}_{2}$ )

Dacite

(63.0 to 69.9 wt. $\% \mathrm{SiO}_{2}$ )

Andesite

(57.0 to 62.9 wt. $\% \mathrm{SiO}_{2}$ )

Basaltic Andesite

(53.0 to 56.9 wt. \% $\mathrm{SiO}_{2}$ )

Basalt

(<53.0 wt.\% $\mathrm{SiO}_{2}$ ) 
The large volume of lava flows issuing from the perimeter of the caldera in Period 3 indicates that ring faults were well established and contributing to constructional processes by this point as they conducted magma toward the surface. Eruptions along the rim probably increased topographic relief by constructional means and coeval subsidence of the caldera floor from magma chamber deflation. The ring faults were eventually concealed, but the zones of weakness and fracturing they created continue to play a role in the growth of the volcano since eruptions around the margin, along with flank eruptions, have continued through Period 5. Of the nine known eruptions in the past 5.2 $\mathrm{ka}$, five have been in close proximity to the margin of the topographic rim including the most recent eruption that formed Glass mountain about 890 years ago (Donnelly-Nolan, et al. 2007).

Caldera subsidence is also ongoing. Dzurisin et al. (2002) used leveling surveys to establish that the center of the basin is subsiding at rates of $4.9 \mathrm{~mm} / \mathrm{yr}$ relative to the topographic rim and at $8.6 \mathrm{~mm} / \mathrm{yr}$ relative to the margin of the volcano. Modern subsidence may be due to loading of thermally weakened crust by the mass of the volcano, the thinning of locally weakened crust by Basin and Range extension (Dzurisin et al., 2002), and cooling beneath the volcano (Poland et al., 2006). The $4.9 \mathrm{~mm} / \mathrm{yr}$ subsidence rate is much higher than the historical rate of $1.3-2.4 \mathrm{~mm} / \mathrm{yr}$ based on vertical offset of the ash-flow tuff since it was emplaced. A possible explanation for these differences may be that some degree of magma chamber inflation and resurgence has occurred between historical eruptions, resulting in a slower overall subsidence rate. Such a process would also help to keep ring faults open that might otherwise be sealed by residual magmas, thereby promoting continuing constructional volcanism. 
Although caldera collapse rather than regional tectonic mechanisms appears to control the topography at the summit of MLV, east-west extension and northwestsoutheast dextral shear may both may play a role in the location, initiation, and growth of the volcano.

\section{Tectonic Controls on the Location of MLV}

The interaction of several regional tectonic features is a likely cause for the location and existence of Medicine Lake Volcano. Basin and Range extension began about $17 \mathrm{Ma}$ and is manifested near the western margin of the summit basin by the Little

Glass Mountain Fault Zone (USGS, 1971; Union, 1975; Nordquist and Thompson, 1990). Faulds et al. (2005) infer that strike-slip faulting in the northern Walker Lane (Fig. 1.3) began as early as $9 \mathrm{Ma}$ in the southeast and as late as $3 \mathrm{Ma}$ in the northwest. If Walker Lane dextral shear began to propagate northwest into the MLV area by about $500 \mathrm{Ka}$, it could play a role in the development of MLV. If the normal faults of the Little Glass Mountain Fault Zone, Walker Lane dextral shear, and the Mount Shasta volcanic highland all intersect at the western margin of the topographic ring, their intersection could result in a localized zone of weakened crust allowing magma to rise and initiate the development of Medicine Lake Volcano. The complex interaction of these tectonic systems could be the reason for the "kink" noted by Donnelly-Nolan et al. (2008) where NNW striking faults from the south turn NNE before returning to north and NNW orientations (Fig. 4.3). The interaction may also explain why some of the $\mathrm{P}$ and $\mathrm{T}$ axes from the oriented core, especially in the W3 series from ML14-23, are so scattered.

This intersection interpretation resembles the proposal of Heiken (1978, as cited in Nordquist, 1985, and Donnelly-Nolan et al., 2008), who interpreted the volcano to 
have formed at the intersection of regional north- and northwest-striking normal faults. East-west extension appears to govern the location of many vents and is probably the most important factor controlling volcanic activity. Donnelly-Nolan et al. (1990) proposed that volcanism at MLV is likely caused by basaltic intrusions occurring during east-west crustal stretching in an extensional tectonic environment. Additionally, vent alignments strongly suggest that pre-existing normal faults are the most common ascent path for erupting lavas (Evans and Zucca, 1988) or at least control vent location (Donnelly-Nolan, 1988). Therefore, it is reasonable to conclude that while regional tectonic mechanisms do govern Medicine Lake volcanism, the resulting volcanism bears primary responsibility for the observed topography at the summit of Medicine Lake Volcano. 


\section{CHAPTER 5}

\section{CONCLUSIONS}

The $7 \times 12 \mathrm{~km}$ basin at the summit of Medicine Lake Volcano was formed by a combination of caldera collapse and constructional volcanism. Caldera collapse was probably triggered at about 180 ka by the only eruption known to have produced an ashflow tuff. However, the volume of this tuff is too small to have generated any more than a few 10s of meters of subsidence, which is a small fraction of observed relief. Magma chamber deflation related to flank eruptions between the initiation of the volcanic focus at about $500 \mathrm{ka}$ and the eruption of the ash-flow tuff may have contributed to caldera formation. However, the stratigraphic correlation of the ash-flow tuff between the center and the margins of the caldera suggests that most, if not all, of the subsidence occurred after the tuff was emplaced.

Caldera collapse initiated an elliptical system of ring faults that became conduits for future eruptions around the caldera rim. These eruptions obscured the original ring faults and increased the topographic relief through constructional processes and subsidence resulting from magma chamber deflation. Summit eruptions controlled by the ring fault system have continued through the latest Holocene, with the latest flow being emplaced only 890 years ago.

Data from field observations and fracture striae in oriented and unoriented core samples suggest that a component of regional dextral shear may be present at Medicine 
Lake Volcano. This dextral shear likely involves late Pleistocene northwestward propagation of the Walker Lane fault system. Although dextral shear appears to be present, fault patterns and patterns of $\mathrm{P}$ and $\mathrm{T}$ axes derived from fault striae in oriented core and field measurements are not consistent with a pull-apart basin at the summit of the volcano.

Analysis of $\mathrm{P}$ and $\mathrm{T}$ axes suggests that regional east-west extension dominates the far-field stress regime at MLV. This extension likely causes the alignment of numerous vents across the flanks of the volcano. Regional extension may play a minor role in E-W elongation of the caldera, but the data do not suggest that rifting created the basin. The intersection of northwest-striking normal faults, the Mount Shasta-Medicine Lake Volcanic highland, and Walker Lane dextral shear probably contributed to the location, initiation, and growth of MLV. Additionally, the intersection of these tectonic features may also be the reason that northwest-striking faults from the south turn to a northeastward strike near the volcano before returning to a northwest orientation. The orientations of most of the volcanic vents across the MLV shield are strongly influenced by normal faults related to east-west extension suggesting strong correlation between faulting and growth of the volcano. Regional tectonic faulting plays a large role at Medicine Lake Volcano, but it is clear that local volcanic processes created the distinctive topography at the summit. 
APPENDIX A

USGS QUATERNARY FAULT AND FOLD DATABASE 
Table A. 1

USGS Quaternary Fault and Fold Database faults from the Medford $1^{\circ} \times 2^{\circ}$ sheet.

\begin{tabular}{|c|c|c|c|c|c|c|}
\hline $\begin{array}{c}\text { Fault } \\
\text { Number }\end{array}$ & Fault Name & $\begin{array}{l}\text { Average } \\
\text { Strike }\end{array}$ & Dip & Slip Sense & Comments & Source \\
\hline $843 a$ & $\begin{array}{l}\text { Klamath Graben FS, West Klamath } \\
\text { Lake }\end{array}$ & $355^{\circ}$ & $\begin{array}{l}\text { Est. } 70^{\circ} \mathrm{E}, \\
\mathrm{W}\end{array}$ & Normal & & Personius, 2002c \\
\hline 1807 & Mount Mazama Ring Faults & $0-360^{\circ}$ & $>45^{\circ}$ & Normal & & Personius, 2002a \\
\hline
\end{tabular}

Table A. 2

USGS Quaternary Fault and Fold DataBase faults from the Klamath Falls $1^{\circ} \times 2^{\circ}$ sheet.

\begin{tabular}{|c|c|c|c|c|c|c|}
\hline $\begin{array}{c}\text { Fault } \\
\text { Number }\end{array}$ & Fault Name & $\begin{array}{c}\text { Average } \\
\text { Strike }\end{array}$ & Dip & Slip Sense & Comments & Source \\
\hline 828 & Goose Lake Graben Faults & $351^{\circ}$ & $>45^{\circ}$ & Normal & & Personius, 2002d \\
\hline $829 a$ & $\begin{array}{l}\text { Abert Rim Fault, Lake Abert } \\
\text { Section }\end{array}$ & $014^{\circ}$ & Est. $70^{\circ}$ & Normal & $\begin{array}{l}\text { Sinistral } \\
\text { Component? }\end{array}$ & Personius, 2002e \\
\hline
\end{tabular}


Table A.2 (Cont.)

\begin{tabular}{|c|c|c|c|c|c|c|}
\hline $\begin{array}{c}\text { Fault } \\
\text { Number }\end{array}$ & Fault Name & $\begin{array}{l}\text { Average } \\
\text { Strike }\end{array}$ & Dip & Slip Sense & Comments & Source \\
\hline 830 & Unnamed Faults N. of Abert Lake & $324^{\circ}$ & $>45^{\circ}$ & Normal & & Personius, 2002f \\
\hline $831 \mathrm{a}$ & $\begin{array}{l}\text { Winter Rim FS, Slide Mountain } \\
\text { Section }\end{array}$ & $303^{\circ}$ & Est. $70^{\circ} \mathrm{NE}$ & Normal & $\begin{array}{l}\text { Sinistral } \\
\text { Component? }\end{array}$ & Personius, $2002 \mathrm{~g}$ \\
\hline $831 b$ & $\begin{array}{l}\text { Winter Rim FS, Winter Ridge } \\
\text { Section }\end{array}$ & $356^{\circ}$ & Est. $70^{\circ} \mathrm{E}$ & Normal & & Personius, $2002 \mathrm{~h}$ \\
\hline $831 \mathrm{c}$ & Winter Rim FS, Ana River Section & $345^{\circ}$ & Est. $70^{\circ} \mathrm{E}$ & Normal & $\begin{array}{l}\text { Sinistral } \\
\text { Component? }\end{array}$ & Personius, $2002 \mathrm{i}$ \\
\hline 832 & Faults E. of Summer Lake & $344^{\circ}$ & $>45^{\circ}$ & Normal & & Personius, $2002 \mathrm{j}$ \\
\hline $839 \mathrm{a}$ & $\begin{array}{l}\text { Chemult Grabed FS, Western } \\
\text { Section }\end{array}$ & $014^{\circ}$ & $\begin{array}{l}60^{\circ}-70^{\circ} \mathrm{E} \\
\mathrm{W}\end{array}$ & Normal & & Personius, 2002k \\
\hline 840 & Modoc Plateau Faults & $340^{\circ}$ & $\begin{array}{l}50^{\circ}-60^{\circ} \mathrm{SW} \\
\mathrm{NE}\end{array}$ & Normal & & Personius, 20021 \\
\hline $843 b$ & $\begin{array}{l}\text { Klamath Grabedn FZ, East } \\
\text { Klamath Lake }\end{array}$ & $345^{\circ}$ & Est. $70^{\circ} \mathrm{W}$ & Normal & & Personius, $2002 \mathrm{~m}$ \\
\hline $843 \mathrm{c}$ & $\begin{array}{l}\text { Klamath Grabedn FZ, South } \\
\text { Klamath Lake }\end{array}$ & $329^{\circ}$ & $\begin{array}{l}51^{\circ}-58^{\circ} \mathrm{W} \\
\mathrm{E}\end{array}$ & Normal & & Personius, $2002 n$ \\
\hline 1806 & Newberry Volcano Ring Faults ${ }^{1}$ & $0-360^{\circ}$ & $>45^{\circ}$ & Normal & & Personius, 2002b \\
\hline
\end{tabular}

${ }^{1}$ From Crescent $1^{\circ} \times 2^{\circ}$ sheet. 
Table A.3

USGS Quaternary Fault and Fold Database faults from the Adel $1^{\circ} \times 2^{\circ}$ sheet.

\begin{tabular}{|c|c|c|c|c|c|c|}
\hline $\begin{array}{c}\text { Fault } \\
\text { Number }\end{array}$ & Fault Name & $\begin{array}{l}\text { Average } \\
\text { Strike }\end{array}$ & Dip & Slip Sense & Comments & Source \\
\hline 819 & Brothers FZ & $317^{\circ}$ & $>45^{\circ}$ & Normal? & $\begin{array}{l}\text { Dextral } \\
\text { Component? }\end{array}$ & Personius, 2002o \\
\hline 821 & Donner und Blitzen Fault & $018^{\circ}$ & & Normal & $\begin{array}{l}\text { Dextral } \\
\text { Component? }\end{array}$ & Personius, $2002 p$ \\
\hline 822 & Unnamed Fault near V Lake & $291^{\circ}$ & $>45^{\circ}$ & Normal? & $\begin{array}{l}\text { Dextral } \\
\text { Component? }\end{array}$ & Personius, $2002 q$ \\
\hline 823 & Unnamed Fault near Dry Valley & $021^{\circ}$ & $>45^{\circ}$ & Normal & & Personius, 2002r \\
\hline $824 a$ & $\begin{array}{l}\text { Unnamed Catlow Valley Faults, } \\
\text { Catlow Valley Section }\end{array}$ & $358^{\circ}$ & $>45^{\circ}$ & Normal & & Personius, 2002s \\
\hline $824 b$ & $\begin{array}{l}\text { Unnamed Catlow Valley Faults, } \\
\text { Hawksy Walksy Valley Section }\end{array}$ & $008^{\circ}$ & $>45^{\circ}$ & Normal & & Personius, $2002 \mathrm{t}$ \\
\hline $827 \mathrm{a}$ & $\begin{array}{l}\text { Warner Valley Faults, East Warner } \\
\text { Valley Section }\end{array}$ & $009^{\circ}$ & Est. $70^{\circ}$ & Normal & $\begin{array}{l}\text { Dextral } \\
\text { Component? }\end{array}$ & $\begin{array}{l}\text { Personius and Sawyer, } \\
2002 \mathrm{a}\end{array}$ \\
\hline $827 b$ & $\begin{array}{l}\text { Warner Valley Faults, West } \\
\text { Warner Valley Section }\end{array}$ & $003^{\circ}$ & Est. $70^{\circ}$ & Normal & $\begin{array}{l}\text { Dextral } \\
\text { Component? }\end{array}$ & $\begin{array}{l}\text { Personius and Sawyer, } \\
2002 b\end{array}$ \\
\hline
\end{tabular}




\begin{tabular}{|c|c|c|c|c|c|c|}
\hline \multicolumn{7}{|c|}{ Table A.3 (Cont.) } \\
\hline $\begin{array}{c}\text { Fault } \\
\text { Number }\end{array}$ & Fault Name & $\begin{array}{l}\text { Average } \\
\text { Strike }\end{array}$ & Dip & Slip Sense & Comments & Source \\
\hline $829 b$ & Abert Rim Fault, Northern Section & $017^{\circ}$ & Est. $70^{\circ}$ & Normal & $\begin{array}{l}\text { Sinistral } \\
\text { Component? }\end{array}$ & Personius, $2002 u$ \\
\hline $856 b$ & Steens FZ, Mann Lake Section & $029^{\circ}$ & $>45^{\circ}$ & Normal & & Personius, $2002 \mathrm{v}$ \\
\hline $856 c$ & Steens FZ, Alvord Section & $001^{\circ}$ & $72^{\circ}$ & Normal & $\begin{array}{l}\text { S-S } \\
\text { component? }\end{array}$ & Personius, 2002w \\
\hline $856 \mathrm{~d}$ & Steens FZ, Fields Section & $013^{\circ}$ & $>45^{\circ}$ & Normal & & Personius, $2002 x$ \\
\hline $856 \mathrm{e}$ & Steens FZ, Tum Tum Section & $336^{\circ}$ & $>45^{\circ}$ & Normal & & Personius, $2002 \mathrm{y}$ \\
\hline $856 f$ & Steens FZ, Denio Section & $010^{\circ}$ & $>45^{\circ}$ & Normal & & $\begin{array}{l}\text { Personius and Sawyer, } \\
2002 c\end{array}$ \\
\hline 857 & Mickey Basin Faults & $033^{\circ}$ & $>45^{\circ}$ & Normal & & Personius, $2002 z$ \\
\hline 858 & Tule Springs Rim Fault & $011^{\circ}$ & $>45^{\circ}$ & Normal & & Personius, 2002aa \\
\hline 1490 & East Pueblo Valley FZ & $017^{\circ}$ & $>45^{\circ}$ & Normal & & $\begin{array}{l}\text { Sawyer and Personius, } \\
2003\end{array}$ \\
\hline 1800 & $\begin{array}{l}\text { Unnamed Sheepshead Mountain } \\
\text { Fault }\end{array}$ & $348^{\circ}$ & $>45^{\circ}$ & Normal & & Personius, 2002ab \\
\hline
\end{tabular}


Table A.4

USGS Quaternary Fault and Fold Database faults from the Weed $1^{\circ} \times 2^{\circ}$ sheet.

\begin{tabular}{|c|c|c|c|c|c|c|}
\hline $\begin{array}{c}\text { Fault } \\
\text { Number }\end{array}$ & Fault Name & $\begin{array}{l}\text { Average } \\
\text { Strike }\end{array}$ & Dip & Slip Sense & Comments & Source \\
\hline $2 a$ & $\begin{array}{l}\text { Cedar Mountain FS, Mahogany } \\
\text { Mountain Section }\end{array}$ & $334^{\circ}$ & $\begin{array}{l}\text { Est. } 50^{\circ}-70^{\circ} \\
\text { SW }\end{array}$ & Normal & & Bryant, 2000b \\
\hline $2 b$ & $\begin{array}{l}\text { Cedar Mountain FS, Cedar } \\
\text { Mountain Section }\end{array}$ & $344^{\circ}$ & Est. $50^{\circ}-70^{\circ} \mathrm{E}$ & Normal & & Bryant, 2000c \\
\hline $2 \mathrm{c}$ & $\begin{array}{l}\text { Cedar Mountain FS, Ikes } \\
\text { Mountain-Mt. Hebron Section }\end{array}$ & $345^{\circ}$ & Est. $50^{\circ}-70^{\circ} \mathrm{E}$ & Normal & & Bryant, 2000d \\
\hline 147 & Lost Man Fault & & & & & \\
\hline 148 & Surpur Creek Fault & & & & & \\
\hline 149 & Yellow Butte Fault & & & & & \\
\hline
\end{tabular}


Table A.5

USGS Quaternary Fault and Fold Database faults from the Alturas $1^{\circ} \times 2^{\circ}$ sheet.

\begin{tabular}{|c|c|c|c|c|c|c|}
\hline $\begin{array}{c}\text { Fault } \\
\text { Number }\end{array}$ & Fault Name & $\begin{array}{l}\text { Average } \\
\text { Strike }\end{array}$ & Dip & Slip Sense & Comments & Source \\
\hline $2 \mathrm{~d}$ & $\begin{array}{l}\text { Cedar Mountain FS, Stephes Pass } \\
\text { Section }\end{array}$ & $023^{\circ}$ & $\begin{array}{l}\text { Est. } 35^{\circ}-45^{\circ} \\
\text { E }\end{array}$ & Normal & & Bryant, 2000e \\
\hline 3 & Gillem-Big Crack FS & $355^{\circ}$ & $\begin{array}{l}\text { Est. } 50^{\circ}-70^{\circ} \\
\text { E }\end{array}$ & Normal & & Bryant, 2000a \\
\hline 4 & Surprise Valley Fault & $352^{\circ}$ & $60^{\circ}-67^{\circ}$ & Normal & & Bryant, 2000f \\
\hline 6 & Mayfield FZ & $345^{\circ}$ & $>45^{\circ}$ & Normal & & Bryant, 1995 \\
\hline 164 & Jess Valley FZ & & & & & \\
\hline 172 & Stoney Creek Fault & & & & & \\
\hline 173 & $\begin{array}{l}\text { Unnamed Faults of Devils Garden } \\
\text { Plateau }\end{array}$ & & & & & \\
\hline 174 & Fitzhugh Creek FZ & & & & & \\
\hline
\end{tabular}


Table A.5 (Cont.)

\begin{tabular}{|c|c|c|c|c|c|c|}
\hline $\begin{array}{l}\text { Fault } \\
\text { Number }\end{array}$ & Fault Name & $\begin{array}{l}\text { Average } \\
\text { Strike }\end{array}$ & Dip & Slip Sense & Comments & Source \\
\hline 175 & Davis Creek FZ & & & & & \\
\hline 176 & Lake City Fault & & & & & \\
\hline 177 & Nelson Corral Fault & & & & & \\
\hline 178 & Unnamed Faults in Big Valley Area & & & & & \\
\hline 195 & Black Fox Mountain Fault & & & & & \\
\hline 196 & Ash Creek Fault & & & & & \\
\hline 198 & $\begin{array}{l}\text { Unnamed Fault E. of Donovan } \\
\text { Reservoir }\end{array}$ & & & & & \\
\hline 199 & $\begin{array}{l}\text { Unnamed Fault E. of North Likely } \\
\text { Fault }\end{array}$ & & & & & \\
\hline 200 & $\begin{array}{l}\text { Unnamed Fault S. of Devils Garden } \\
\text { Plateau }\end{array}$ & & & & & \\
\hline 201 & $\begin{array}{l}\text { Unnamed Fault W. of Fitzhugh } \\
\text { Creek FZ }\end{array}$ & & & & & \\
\hline 207 & $\begin{array}{l}\text { Unnamed Faults in Hambone-Dana } \\
\text { Area }\end{array}$ & & & & & \\
\hline 844 & Sky Lakes FZ & $342^{\circ}$ & Est. $70^{\circ}$ & Normal & & Personius, 2002ac \\
\hline
\end{tabular}


Table A.6

USGS Quaternary Fault and Fold Database faults from the Vya $1^{\circ} \times 2^{\circ}$ sheet.

\begin{tabular}{|c|c|c|c|c|c|c|}
\hline $\begin{array}{l}\text { Fault } \\
\text { Number }\end{array}$ & Fault Name & $\begin{array}{l}\text { Average } \\
\text { Strike }\end{array}$ & Dip & Slip Sense & Comments & Source \\
\hline 826 & Unnamed Guano Valley Faults & $009^{\circ}$ & $>45^{\circ}$ & Normal & $\begin{array}{l}\text { Dextral } \\
\text { Component }\end{array}$ & $\begin{array}{l}\text { Personius and Sawyer, } \\
\text { 2002d }\end{array}$ \\
\hline $827 \mathrm{c}$ & $\begin{array}{l}\text { Warner Valley Faults, Coleman } \\
\text { Valley Section }\end{array}$ & $353^{\circ}$ & $>45^{\circ}$ & Normal (I) & & $\begin{array}{l}\text { Personius and Lidke, } \\
2002\end{array}$ \\
\hline 1463 & $\begin{array}{l}\text { Unnamed Fault in Coppersmith } \\
\text { Hills }\end{array}$ & $024^{\circ}$ & NDA & Normal (I) & & Sawyer, 1998a \\
\hline 1464 & Hays Canyon Range FZ & $001^{\circ}$ & NDA & Normal (I) & & Sawyer, 1998b \\
\hline 1465 & $\begin{array}{l}\text { Unnamed FZ in Hays Canyon } \\
\text { Range }\end{array}$ & $002^{\circ}$ & NDA & Normal (I) & & Sawyer, 1998c \\
\hline 1466 & Vya Fault & $357^{\circ}$ & $\mathrm{NDA}$ & Normal & & Sawyer, 1998d \\
\hline 1468 & $\begin{array}{l}\text { Unnamed Fault S.E. of Mosquito } \\
\text { Valley }\end{array}$ & $020^{\circ}$ & NDA & Normal & & Sawyer, 1998e \\
\hline 1470 & Unnamed FZ in Long Valley & $030^{\circ}$ & NDA & Normal (I) & & Sawyer, $1998 \mathrm{f}$ \\
\hline
\end{tabular}




\begin{tabular}{|c|c|c|c|c|c|c|}
\hline $\begin{array}{c}\text { Fault } \\
\text { Number }\end{array}$ & Fault Name & $\begin{array}{l}\text { Average } \\
\text { Strike }\end{array}$ & Dip & Slip Sense & Comments & Source \\
\hline 1472 & Duck Flat Fault & $001^{\circ}$ & NDA & Normal (I) & & Sawyer, $1998 \mathrm{~g}$ \\
\hline 1474 & Unnamed FZ near Bordwell Spring & $013^{\circ}$ & NDA & Normal & & Sawyer, $1998 \mathrm{~h}$ \\
\hline 1475 & Unnamed Fault near Pinto Peak & $344^{\circ}$ & NDA & Normal & & Sawyer, 1998i \\
\hline 1476 & $\begin{array}{l}\text { Unnamed Fault near Massacre } \\
\text { Lake }\end{array}$ & $313^{\circ}$ & NDA & Normal (I) & & Sawyer, 1998j \\
\hline 1478 & Unnamed Fault near Gooch Lake & $010^{\circ}$ & NDA & Normal (I) & & Sawyer, 1999a \\
\hline 1479 & $\begin{array}{l}\text { Unnamed Faults near Rock Spring } \\
\text { Table }\end{array}$ & $317^{\circ}$ & NDA & Normal (I) & & Sawyer, 1998k \\
\hline 1480 & $\begin{array}{l}\text { Unnamed FZ near Badger } \\
\text { Mountain }\end{array}$ & $336^{\circ}$ & NDA & Normal (I) & & Sawyer, 19981 \\
\hline 1481 & $\begin{array}{l}\text { Unnamed Fault near Hanging Rock } \\
\text { Canyon }\end{array}$ & $322^{\circ}$ & NDA & Normal & & Sawyer, $1998 \mathrm{~m}$ \\
\hline 1482 & $\begin{array}{l}\text { Unnamed Fault near High Rock } \\
\text { Canyon }\end{array}$ & $339^{\circ}$ & NDA & Normal & & Sawyer, 1998n \\
\hline 1483 & $\begin{array}{l}\text { Unnamed Faults near Hog Ranch } \\
\text { Creek }\end{array}$ & $352^{\circ}$ & NDA & Normal & & Sawyer, 19980 \\
\hline
\end{tabular}




\begin{tabular}{|c|c|c|c|c|c|c|}
\hline $\begin{array}{l}\text { Fault } \\
\text { Number }\end{array}$ & Fault Name & $\begin{array}{l}\text { Average } \\
\text { Strike }\end{array}$ & Dip & Slip Sense & Comments & Source \\
\hline 1484 & $\begin{array}{l}\text { Unnamed Fault along Western } \\
\text { Calico Mountains }\end{array}$ & $002^{\circ}$ & NDA & Normal & & $\begin{array}{l}\text { Sawyer and Adams, } \\
\text { 1998a }\end{array}$ \\
\hline 1485 & Black Rock FZ & $008^{\circ}$ & $55^{\circ} \mathrm{W}-90^{\circ}$ & Normal & & $\begin{array}{l}\text { Sawyer and Adams, } \\
1998 \text { b }\end{array}$ \\
\hline 1486 & $\begin{array}{l}\text { Unnamed Faults in Northern Black } \\
\text { Rock Desert }\end{array}$ & $012^{\circ}$ & NDA & Normal & & Sawyer, 1998p \\
\hline 1487 & $\begin{array}{l}\text { Unnamed Faults S.E. of Fivemile } \\
\text { Flat }\end{array}$ & $031^{\circ}$ & NDA & Normal & & Sawyer, 1998q \\
\hline 1488 & McGee Mountain FZ & $348^{\circ}$ & NDA & Normal & & Sawyer, 1998r \\
\hline 1491 & $\begin{array}{l}\text { Unnamed FZ S.W. of Pine Forest } \\
\text { Range }\end{array}$ & $009^{\circ}$ & NDA & Normal (I) & & Sawyer, 1998s \\
\hline 1492 & $\begin{array}{l}\text { Unnamed Faults S.E. of Pine Forest } \\
\text { Range }\end{array}$ & $031^{\circ}$ & NDA & Normal & & Sawyer, 1998t \\
\hline 1493 & $\begin{array}{l}\text { Unnamed Faults W. of Black Rock } \\
\text { Desert }\end{array}$ & $017^{\circ}$ & NDA & Normal & & Sawyer, 1998u \\
\hline 1494 & Jackson Mountains FZ & $014^{\circ}$ & NDA & Normal & & Sawyer, 1999b \\
\hline $1495 \mathrm{a}$ & $\begin{array}{l}\text { Eastern Pine Forest Range FZ, } \\
\text { Northern Section }\end{array}$ & $006^{\circ}$ & NDA & Normal & & Sawyer, 1998v \\
\hline
\end{tabular}




\begin{tabular}{|c|c|c|c|c|c|c|}
\hline $\begin{array}{l}\text { Fault } \\
\text { Number }\end{array}$ & Fault Name & $\begin{array}{l}\text { Average } \\
\text { Strike }\end{array}$ & Dip & Slip Sense & Comments & Source \\
\hline $1495 b$ & $\begin{array}{l}\text { Eastern Pine Forest Range FZ, } \\
\text { Southern Section }\end{array}$ & $001^{\circ}$ & NDA & Normal & & Sawyer, 1998w \\
\hline 1496 & Eastern Bilk Creek Mountains FZ & $348^{\circ}$ & NDA & Normal & & Sawyer, 1998x \\
\hline 1497 & $\begin{array}{l}\text { Unnamed Faults S.W. of Bilk } \\
\text { Creek }\end{array}$ & $350^{\circ}$ & NDA & Normal & & Sawyer, 1998y \\
\hline 1498 & Eastern Jackson Mountains FZ & $004^{\circ}$ & NDA & Normal & & Sawyer, $1998 z$ \\
\hline 1499 & $\begin{array}{l}\text { Unnamed FZ Southeastern Jackson } \\
\text { Mountains }\end{array}$ & $011^{\circ}$ & NDA & Normal & & Sawyer, 1998aa \\
\hline 1500 & $\begin{array}{l}\text { Unnamed Faults bounding Blue } \\
\text { Mountain }\end{array}$ & $343^{\circ}$ & NDA & Normal (I) & & $\begin{array}{l}\text { Sawyer and Adams, } \\
1999 \mathrm{~b}\end{array}$ \\
\hline $1501 \mathrm{a}$ & $\begin{array}{l}\text { Montana Mountains/ Desert Valley } \\
\text { FZ, N. Section }\end{array}$ & $344^{\circ}$ & NDA & Normal & & Sawyer, 1998ab \\
\hline $1501 b$ & $\begin{array}{l}\text { Montana Mountains/ Desert Valley } \\
\text { FZ, S. Section }\end{array}$ & $004^{\circ}$ & NDA & Normal & & Sawyer, 1998ac \\
\hline 1502 & $\begin{array}{l}\text { Unnamed Faults in the Northern } \\
\text { Double H Mountains }\end{array}$ & $303^{\circ}$ & NDA & Normal (I) & & Sawyer, 1998ad \\
\hline 1503 & $\begin{array}{l}\text { Unnamed FZ E. of Trout Creek } \\
\text { Mountains }\end{array}$ & $341^{\circ}$ & NDA & Normal (I) & & Sawyer, 1998ae \\
\hline
\end{tabular}


Table A.7

USGS Quaternary Fault and Fold Database faults from the Redding $1^{\circ} \times 2^{\circ}$ sheet.

\begin{tabular}{|c|c|c|c|c|c|c|}
\hline $\begin{array}{c}\text { Fault } \\
\text { Number }\end{array}$ & Fault Name & $\begin{array}{l}\text { Average } \\
\text { Strike }\end{array}$ & Dip & Slip Sense & Comments & Source \\
\hline 11 & Grogan Fault & $337^{\circ}$ & $65^{\circ}-90^{\circ}$ & Dextral & & Hart, 1999a \\
\hline 12 & Bald Mountain-Big Lagoon FZ & $338^{\circ}$ & $30^{\circ} \mathrm{NE}$ & Thrust & & Hart, 1999b \\
\hline 13 & Mad River FZ & $322^{\circ}$ & $25^{\circ}-45^{\circ} \mathrm{NE}$ & Thrust & & Hart, 1999c \\
\hline 15 & Little Salmon FZ & $316^{\circ}$ & $25^{\circ}-35^{\circ} \mathrm{NE}$ & Thrust & & Hart, 1999d \\
\hline 17 & Eaton Roughs Fault & & & & & \\
\hline 19 & Garberville-Briceland FZ & & & & & \\
\hline 20 & Battle Creek Fault & & & & & \\
\hline $29 \mathrm{a}$ & $\begin{array}{l}\text { Bartlett Springs FS, Lake Mountain } \\
\text { Section }\end{array}$ & $345^{\circ}$ & $90^{\circ}$ & Dextral & & Bryant, 2000g \\
\hline
\end{tabular}


Table A.7 (Cont.)

\begin{tabular}{cccccc}
\hline $\begin{array}{c}\text { Fault } \\
\text { Number }\end{array}$ & Fault Name & $\begin{array}{c}\text { Average } \\
\text { Strike }\end{array}$ & Dip & Slip Sense & Comments \\
\hline
\end{tabular}

$150 \quad$ Russ FZ

156 Whale Gulch-Bear Harbor FZ

$158 \quad$ Corning Fault

160 Unnamed Fault between Eaton Roughs Fault and Garberville-

Briceland FZ

162 Unnamed FZ E. of Northern

Garberville-Briceland FZ

163 Unnamed FZ S.W. of Northern

Garberville-Briceland FZ 
Table A.8

USGS Quaternary Fault and Fold Database faults from the Susanville $1^{\circ} \times 2^{\circ}$ sheet.

\begin{tabular}{|c|c|c|c|c|c|c|}
\hline $\begin{array}{l}\text { Fault } \\
\text { Number }\end{array}$ & Fault Name & $\begin{array}{l}\text { Average } \\
\text { Strike }\end{array}$ & Dip & Slip Sense & Comments & Source \\
\hline 5 & Likely FZ & $325^{\circ}$ & $>45^{\circ}$ & Dextral & $\begin{array}{l}\text { Normal } \\
\text { Component }\end{array}$ & $\begin{array}{l}\text { Sawyer and Bryant, } \\
1995\end{array}$ \\
\hline 7 & Pittville Fault & $344^{\circ}$ & $>45^{\circ} \mathrm{W}$ & Normal & & Sawyer, 1995c \\
\hline 8 & McArthur FZ & $343^{\circ}$ & $>45^{\circ} \mathrm{W}$ & Normal & $\begin{array}{l}\text { Dextral } \\
\text { Component? }\end{array}$ & Sawyer, 1995a \\
\hline 9 & Hat Creek FZ & $345^{\circ}$ & $>45^{\circ} \mathrm{E}$ & Normal & $\begin{array}{l}\text { Dextral } \\
\text { Component? }\end{array}$ & Sawyer, 1995b \\
\hline 10 & Rocky Ledge FZ & $350^{\circ}$ & $>45^{\circ} \mathrm{W}$ & Normal & & Sawyer, 1995d \\
\hline 20 & Battle Creek Fault & & & & & \\
\hline 21 & Almanor FZ & $346^{\circ}$ & $>45^{\circ} \mathrm{W}$ & Normal & $\begin{array}{l}\text { Sinistral } \\
\text { Component? }\end{array}$ & Bryant, 2000h \\
\hline 22 & Honey Lake FZ & & & & & \\
\hline
\end{tabular}


Table A.8 (Cont.)

\begin{tabular}{|c|c|c|c|c|c|c|}
\hline $\begin{array}{c}\text { Fault } \\
\text { Number }\end{array}$ & Fault Name & $\begin{array}{l}\text { Average } \\
\text { Strike }\end{array}$ & Dip & Slip Sense & Comments & Source \\
\hline 23 & Indian Lake FZ & & & & & \\
\hline 24 & Fort Sage Fault & $341^{\circ}$ & $>45^{\circ}$ & Normal & & Sawyer, $1995 \mathrm{e}$ \\
\hline 159 & Chico Monocline & & & & & \\
\hline 179 & $\begin{array}{l}\text { Unnamed FZ in Susanville-Eagle } \\
\text { Lake Area }\end{array}$ & & & & & \\
\hline 189 & Butt Creek FZ & & & & & \\
\hline 190 & Walker Spring Fault & & & & & \\
\hline 191 & Keddie Ridge Fault & & & & & \\
\hline 192 & Skinner Flat Fault & & & & & \\
\hline 193 & Unnamed Faults E. of Eagle Lake & & & & & \\
\hline 197 & Hatchet Mountain Fault & & & & & \\
\hline
\end{tabular}


Table A.8 (Cont.)

\begin{tabular}{|c|c|c|c|c|c|c|}
\hline $\begin{array}{c}\text { Fault } \\
\text { Number }\end{array}$ & Fault Name & $\begin{array}{c}\text { Average } \\
\text { Strike }\end{array}$ & Dip & Slip Sense & Comments & Source \\
\hline 202 & Beaver Creek Fault & & & & & \\
\hline 203 & Cohasset Ridge Fault & & & & & \\
\hline 206 & Unnamed Faults W. of Hat Creek & & & & & \\
\hline 208 & Crablouse Ravine Fault & & & & & \\
\hline 210 & Mosquito Creek Fault & & & & & \\
\hline 211 & Queen Lily Fault & & & & & \\
\hline
\end{tabular}


Table A.9

USGS Quaternary Fault and Fold Database faults from the Lovelock $1^{\circ} \mathrm{x} 2^{\circ}$ sheet.

\begin{tabular}{|c|c|c|c|c|c|c|}
\hline $\begin{array}{l}\text { Fault } \\
\text { Number }\end{array}$ & Fault Name & $\begin{array}{l}\text { Average } \\
\text { Strike }\end{array}$ & Dip & Slip Sense & Comments & Source \\
\hline 1509 & Bloody Run Hills Fault & $354^{\circ}$ & NDA & Normal & & $\begin{array}{l}\text { Adams and Sawyer, } \\
1999 b\end{array}$ \\
\hline 1601 & Bonham Ranch FZ & $001^{\circ}$ & $70^{\circ}-74^{\circ} \mathrm{E}$ & Normal & $\begin{array}{l}\text { Dextral } \\
\text { Component }\end{array}$ & $\begin{array}{l}\text { Adams and Sawyer, } \\
1998\end{array}$ \\
\hline 1602 & $\begin{array}{l}\text { Dry Valley-Smoke Creek Ranch } \\
\text { FZ }\end{array}$ & $353^{\circ}$ & $>45^{\circ}$ & Normal & $\begin{array}{l}\text { Dextral } \\
\text { Component }\end{array}$ & $\begin{array}{l}\text { Adams and Sawyer, } \\
\text { 1999c }\end{array}$ \\
\hline 1603 & Unnamed FZ near Sand Pass & $047^{\circ}$ & $90^{\circ}(\mathrm{I})$ & Sinistral (I) & & $\begin{array}{l}\text { Adams and Sawyer, } \\
\text { 1999a }\end{array}$ \\
\hline 1604 & Alkali Flat Fault & $028^{\circ}$ & NDA & Normal (I) & & $\begin{array}{l}\text { Sawyer and Adams, } \\
\text { 1999c }\end{array}$ \\
\hline 1605 & Warm Springs Valley FZ & $319^{\circ}$ & $>45^{\circ}$ & Dextral & $\begin{array}{l}\text { Normal } \\
\text { Component }\end{array}$ & Sawyer et al., 1999 \\
\hline 1606 & Terraced Hills FZ & $338^{\circ}$ & $>45^{\circ}(\mathrm{I})$ & $\begin{array}{l}\text { Dextral } \\
\text { Oblique }\end{array}$ & & $\begin{array}{l}\text { Sawyer and Adams, } \\
\text { 1999a }\end{array}$ \\
\hline 1607 & Eastern Pyramic Lake Fault & $356^{\circ}$ & & Normal & & $\begin{array}{l}\text { Sawyer and Adams, } \\
\text { 1999d }\end{array}$ \\
\hline
\end{tabular}




\begin{tabular}{|c|c|c|c|c|c|c|}
\hline $\begin{array}{c}\text { Fault } \\
\text { Number }\end{array}$ & Fault Name & $\begin{array}{l}\text { Average } \\
\text { Strike }\end{array}$ & Dip & Slip Sense & Comments & Source \\
\hline 1608 & Fox Range FZ & $011^{\circ}$ & & Normal & $\begin{array}{l}\text { Dextral } \\
\text { Component? }\end{array}$ & $\begin{array}{l}\text { Adams and Sawyer, } \\
\text { 1999d }\end{array}$ \\
\hline 1609 & $\begin{array}{l}\text { Unnamed Faults near Squaw } \\
\text { Valley }\end{array}$ & $002^{\circ}$ & & Normal & & $\begin{array}{l}\text { Sawyer and Adams, } \\
1999 \mathrm{e}\end{array}$ \\
\hline 1610 & Wester Granite Range Fault & $347^{\circ}$ & & Normal & & $\begin{array}{l}\text { Adams and Sawyer, } \\
\text { 1999e }\end{array}$ \\
\hline 1611 & Eastern Granite Range Fault & $333^{\circ}$ & & Normal & & $\begin{array}{l}\text { Sawyer and Adams, } \\
\text { 1999f }\end{array}$ \\
\hline 1612 & Gerlach FZ & $037^{\circ}$ & & Normal & & $\begin{array}{l}\text { Sawyer and Adams, } \\
1999 \mathrm{~g}\end{array}$ \\
\hline 1613 & San Emido FZ & $015^{\circ}$ & & Normal & & $\begin{array}{l}\text { Sawyer and Adams, } \\
1999 \mathrm{~h}\end{array}$ \\
\hline 1614 & Nightingale Mountains FZ & $006^{\circ}$ & & Normal & & $\begin{array}{l}\text { Sawyer and Adams, } \\
\text { 1999i }\end{array}$ \\
\hline 1615 & $\begin{array}{l}\text { Unnamed FZ between Kumiva and } \\
\text { Sage Hen }\end{array}$ & $027^{\circ}$ & & Normal & & $\begin{array}{l}\text { Sawyer and Adams, } \\
1999 \mathrm{j}\end{array}$ \\
\hline 1616 & $\begin{array}{l}\text { Unnamed FZ on E. Side of Selenite } \\
\text { Range }\end{array}$ & $008^{\circ}$ & & Normal (I) & & $\begin{array}{l}\text { Sawyer and Adams, } \\
\text { 1999k }\end{array}$ \\
\hline 1617 & Selenite Range FZ & $009^{\circ}$ & & Normal & & $\begin{array}{l}\text { Sawyer and Adams, } \\
19991\end{array}$ \\
\hline
\end{tabular}




\begin{tabular}{|c|c|c|c|c|c|c|}
\hline $\begin{array}{c}\text { Fault } \\
\text { Number }\end{array}$ & Fault Name & $\begin{array}{l}\text { Average } \\
\text { Strike }\end{array}$ & Dip & Slip Sense & Comments & Source \\
\hline 1618 & Dry Mountain Fault & $020^{\circ}$ & & Normal & & $\begin{array}{l}\text { Adams and Sawyer, } \\
\text { 1999f }\end{array}$ \\
\hline 1619 & Kumiva Valley FZ & $036^{\circ}$ & & Normal & & $\begin{array}{l}\text { Sawyer and Adams, } \\
1999 \mathrm{~m}\end{array}$ \\
\hline 1620 & $\begin{array}{l}\text { Unnamed FZ along Bluewing } \\
\text { Mountains }\end{array}$ & $048^{\circ}$ & & Normal (I) & & $\begin{array}{l}\text { Sawyer and Adams, } \\
1999 \mathrm{n}\end{array}$ \\
\hline 1621 & $\begin{array}{l}\text { Unnamed Faults along Sahwave } \\
\text { Mountains }\end{array}$ & $033^{\circ}$ & & Normal (I) & & $\begin{array}{l}\text { Sawyer and Adams, } \\
19990\end{array}$ \\
\hline 1622 & Granite Springs Valley FZ & $014^{\circ}$ & & Normal & & $\begin{array}{l}\text { Sawyer and Adams, } \\
1999 p\end{array}$ \\
\hline 1623 & Unnamed FZ near the Lava Beds & $001^{\circ}$ & & Normal & & $\begin{array}{l}\text { Sawyer and Adams, } \\
1999 q\end{array}$ \\
\hline 1624 & The Lava Beds Fault & $020^{\circ}$ & & Normal & & $\begin{array}{l}\text { Sawyer and Adams, } \\
1999 \mathrm{r}\end{array}$ \\
\hline 1625 & Unnamed FZ near Sheep Spring & $022^{\circ}$ & & Normal (I) & & $\begin{array}{l}\text { Sawyer and Adams, } \\
1999 \text { s }\end{array}$ \\
\hline 1626 & KammaMountains FZ & $066^{\circ}$ & & Normal & & $\begin{array}{l}\text { Adams and Sawyer, } \\
1999 \mathrm{~g}\end{array}$ \\
\hline 1627 & Seven Troughs Range FZ & $022^{\circ}$ & & Normal & & $\begin{array}{l}\text { Adams and Sawyer, } \\
\text { 1999h }\end{array}$ \\
\hline
\end{tabular}




\begin{tabular}{|c|c|c|c|c|c|c|}
\hline $\begin{array}{c}\text { Fault } \\
\text { Number }\end{array}$ & Fault Name & $\begin{array}{l}\text { Average } \\
\text { Strike }\end{array}$ & Dip & Slip Sense & Comments & Source \\
\hline 1628 & $\begin{array}{l}\text { Unnamed Fault in Granite Springs } \\
\text { Valley }\end{array}$ & $001^{\circ}$ & & Normal (I) & & $\begin{array}{l}\text { Adams and Sawyer, } \\
\text { 1999i }\end{array}$ \\
\hline 1629 & Sage Valley FZ & $032^{\circ}$ & & Normal & & $\begin{array}{l}\text { Adams and Sawyer, } \\
1999 \mathrm{j}\end{array}$ \\
\hline 1630 & $\begin{array}{l}\text { Unnamed Faults in the Southern } \\
\text { Part of the Trinity Range }\end{array}$ & $356^{\circ}$ & & Normal & & $\begin{array}{l}\text { Adams and Sawyer, } \\
\text { 1999k }\end{array}$ \\
\hline 1631 & $\begin{array}{l}\text { Unnamed Faults W. of Rye Patch } \\
\text { Dam }\end{array}$ & $293^{\circ}$ & & Normal (I) & & $\begin{array}{l}\text { Adams and Sawyer, } \\
19991\end{array}$ \\
\hline 1632 & $\begin{array}{l}\text { Unnamed Faults around Majuba } \\
\text { Mountains }\end{array}$ & $296^{\circ}$ & & Normal (I) & & Adams, 1999a \\
\hline 1633 & $\begin{array}{l}\text { Unnamed Faults S. of the Antelope } \\
\text { Range }\end{array}$ & $294^{\circ}$ & & Normal (I) & & Adams, 1999b \\
\hline 1634 & Eugene Mountains Fault & $008^{\circ}$ & & Normal & & Adams, 1999c \\
\hline 1635 & Western Humboldt Range FZ & $012^{\circ}$ & $83^{\circ} \mathrm{NW}$ & Normal & & $\begin{array}{l}\text { Adams and Sawyer, } \\
1999 \mathrm{~m}\end{array}$ \\
\hline 1636 & Unnamed Faults near Packard Flat & $020^{\circ}$ & & Normal & & $\begin{array}{l}\text { Adams and Sawyer, } \\
\text { 1999n }\end{array}$ \\
\hline 1637 & Eastern Humboldt Range & $004^{\circ}$ & & Normal & & $\begin{array}{l}\text { Adams and Sawyer, } \\
\text { 1999o }\end{array}$ \\
\hline
\end{tabular}


Table A.9 (Cont.)

\begin{tabular}{|c|c|c|c|c|c|c|}
\hline $\begin{array}{c}\text { Fault } \\
\text { Number }\end{array}$ & Fault Name & $\begin{array}{l}\text { Average } \\
\text { Strike }\end{array}$ & Dip & Slip Sense & Comments & Source \\
\hline 1638 & Buena Vista FZ & $020^{\circ}$ & & Normal & & Adams et al., 2000 \\
\hline 1678 & $\begin{array}{l}\text { Unnamed FZ on N.W. side of } \\
\text { Trinity Range }\end{array}$ & $022^{\circ}$ & & Normal (I) & & $\begin{array}{l}\text { Adams and Sawyer, } \\
1999 p\end{array}$ \\
\hline
\end{tabular}




\section{REFERENCES}

Acocella, V., Funiciello, R., Marotta, G., and deVita, S., 2004, The role of extensional structures on experimental calderas and resurgence: Journal of Volcanology and Geothermal Research, v. 129, p. 199-217.

Adams, K.D., compiler, 1999a, Fault number 1632, Unnamed faults around Majuba Mountains, in Quaternary fault and fold database of the United States: U.S. Geological Survey website, http://earthquakes.usgs.gov/regional/qfaults, accessed 10/18/2008 04:23 PM.

Adams, K.D., compiler, 1999b, Fault number 1633, Unnamed faults on south side of the Antelope Range, in Quaternary fault and fold database of the United States: U.S. Geological Survey website, http://earthquakes.usgs.gov/regional/qfaults, accessed 10/18/2008 04:25 PM.

Adams, K.D., compiler, 1999c, Fault number 1634, Eugene Mountains fault, in Quaternary fault and fold database of the United States: U.S. Geological Survey website, http://earthquakes.usgs.gov/regional/qfaults, accessed 10/18/2008 04:27 PM.

Adams, K.D., and Sawyer, T.L., compilers, 1998, Fault number 1601, Bonham Ranch fault zone, in Quaternary fault and fold database of the United States: U.S. Geological Survey website, http://earthquakes.usgs.gov/regional/qfaults, accessed 10/18/2008 03:06 PM.

Adams, K.D., and Sawyer, T.L., compilers, 1999a, Fault number 1603, Unnamed fault zone near Sand Pass, in Quaternary fault and fold database of the United States: U.S. Geological Survey website, http://earthquakes.usgs.gov/regional/qfaults, accessed 10/18/2008 03:13 PM.

Adams, K.D., and Sawyer, T.L., compilers, 1999b, Fault number 1509, Bloody Run Hills fault, in Quaternary fault and fold database of the United States: U.S. Geological Survey website, http://earthquakes.usgs.gov/regional/qfaults, accessed 10/18/2008 02:59 PM.

Adams, K.D., and Sawyer, T.L., compilers, 1999c, Fault number 1602, Dry ValleySmoke Creek Ranch fault zone, in Quaternary fault and fold database of the United States: U.S. Geological Survey website, http://earthquakes.usgs.gov/regional/qfaults, accessed 10/18/2008 03:09 PM. 
Adams, K.D., and Sawyer, T.L., compilers, 1999d, Fault number 1608, Fox Range fault zone, in Quaternary fault and fold database of the United States: U.S. Geological Survey website, http://earthquakes.usgs.gov/regional/qfaults, accessed 10/18/2008 03:29 PM.

Adams, K.D., and Sawyer, T.L., compilers, 1999e, Fault number 1610, Western Granite Range fault, in Quaternary fault and fold database of the United States: U.S. Geological Survey website, http://earthquakes.usgs.gov/regional/qfaults, accessed 10/18/2008 03:39 PM.

Adams, K.D., and Sawyer, T.L., compilers, 1999f, Fault number 1618, Dry Mountain fault, in Quaternary fault and fold database of the United States: U.S. Geological Survey website, http://earthquakes.usgs.gov/regional/qfaults, accessed 10/18/2008 03:59 PM.

Adams, K.D., and Sawyer, T.L., compilers, 1999g, Fault number 1626, Kamma Mountains fault zone, in Quaternary fault and fold database of the United States: U.S. Geological Survey website, http://earthquakes.usgs.gov/regional/qfaults, accessed 10/18/2008 04:09 PM.

Adams, K.D., and Sawyer, T.L., compilers, 1999h, Fault number 1627, Seven Troughs Range fault zone, in Quaternary fault and fold database of the United States: U.S. Geological Survey website, http://earthquakes.usgs.gov/regional/qfaults, accessed 10/18/2008 04:11 PM.

Adams, K.D., and Sawyer, T.L., compilers, 1999i, Fault number 1628, Unnamed fault in northern Granite Springs Valley, in Quaternary fault and fold database of the United States: U.S. Geological Survey website, http://earthquakes.usgs.gov/regional/qfaults, accessed 10/18/2008 04:14 PM.

Adams, K.D., and Sawyer, T.L., compilers, 1999j, Fault number 1629, Sage Valley fault zone, in Quaternary fault and fold database of the United States: U.S. Geological Survey website, http://earthquakes.usgs.gov/regional/qfaults, accessed 10/18/2008 04:17 PM.

Adams, K.D., and Sawyer, T.L., compilers, 1999k, Fault number 1630, Unnamed faults in the southern part of the Trinity Range, in Quaternary fault and fold database of the United States: U.S. Geological Survey website, http://earthquakes.usgs.gov/regional/qfaults, accessed 10/18/2008 04:20 PM.

Adams, K.D., and Sawyer, T.L., compilers, 19991, Fault number 1631, Unnamed faults west of Rye Patch Dam, in Quaternary fault and fold database of the United States: U.S. Geological Survey website, http://earthquakes.usgs.gov/regional/qfaults, accessed 10/18/2008 04:22 PM. 
Adams, K.D., and Sawyer, T.L., compilers, 1999m, Fault number 1635, Western Humboldt Range fault zone, in Quaternary fault and fold database of the United States: U.S. Geological Survey website, http://earthquakes.usgs.gov/regional/qfaults, accessed 10/18/2008 04:28 PM.

Adams, K.D., and Sawyer, T.L., compilers, 1999n, Fault number 1636, Unnamed faults near Packard Flat, in Quaternary fault and fold database of the United States: U.S. Geological Survey website, http://earthquakes.usgs.gov/regional/qfaults, accessed 10/18/2008 04:32 PM.

Adams, K.D., and Sawyer, T.L., compilers, 1999o, Fault number 1637, Eastern Humboldt Range fault zone, in Quaternary fault and fold database of the United States: U.S. Geological Survey website, http://earthquakes.usgs.gov/regional/qfaults, accessed 10/18/2008 04:33 PM.

Adams, K.D., and Sawyer, T.L., compilers, 1999p, Fault number 1678, Unnamed fault zone on northwest side of Trinity Range, in Quaternary fault and fold database of the United States: U.S. Geological Survey website, http://earthquakes.usgs.gov/regional/qfaults, accessed 10/18/2008 04:36 PM.

Adams, K.D., Sawyer, T.L., and Anderson, R. E., compilers, 2000, Fault number 1638, Buena Vista Valley fault zone, in Quaternary fault and fold database of the United States: U.S. Geological Survey website, http://earthquakes.usgs.gov/regional/qfaults, accessed 10/18/2008 04:34 PM.

Anderson, C.A., 1941, Volcanoes of the Medicine Lake highland, California: University of California Publications in Geological Sciences, v. 25, p. 347-422.

Anderson, E.M., 1951, The dynamics of faulting and dyke formation: Eidenburgh, Oliver and Boyd, 206 p.

Blakely, R.J., Christiansen, R.L., Guffanti, M., Wells, R.E., Donnelly-Nolan, J.M., Muffler, L.J. P., Clynne, M.A., and Smith, J.G., 1997, Gravity anomalies, Quaternary vents, and Quaternary faults in the southern Cascade Range, Oregon and California: Implications for arc and backarc evolution: Journal of Geophysical Research, v. 102, p. 22513-22527.

BLM, 1999, Telephone Flat geothermal development project environmental impact statement, environmental impact report: DOI/FEIS-99-6. Bureau of Land Management, Northern California District, Alturas Resource Area, Alturas, CA.

Bryant, W.A., compiler, 1995, Fault number 6, Mayfield fault zone, in Quaternary fault and fold database of the United States: U.S. Geological Survey website, http://earthquakes.usgs.gov/regional/qfaults, accessed 10/19/2008 01:22 AM. 
Bryant, W.A., compiler, 2000a, Fault number 3, Gillem-Big Crack fault system, in Quaternary fault and fold database of the United States: U.S. Geological Survey website, http://earthquakes.usgs.gov/regional/qfaults, accessed 10/19/2008 01:17 AM.

Bryant, W.A., compiler, 2000b, Fault number 2a, Cedar Mountain fault system, Mahogany Mountain section, in Quaternary fault and fold database of the United States: U.S. Geological Survey website, http://earthquakes.usgs.gov/regional/qfaults, accessed 10/18/2008 07:16 PM.

Bryant, W.A., compiler, 2000c, Fault number 2b, Cedar Mountain fault system, Cedar Mountain section, in Quaternary fault and fold database of the United States: U.S. Geological Survey website, http://earthquakes.usgs.gov/regional/qfaults, accessed 10/18/2008 07:20 PM.

Bryant, W.A., compiler, 2000d, Fault number 2c, Cedar Mountain fault system, Ikes Mtn.-Mt. Hebron section, in Quaternary fault and fold database of the United States: U.S. Geological Survey website, http://earthquakes.usgs.gov/regional/qfaults, accessed 10/18/2008 07:23 PM.

Bryant, W.A., compiler, 2000e, Fault number 2d, Cedar Mountain fault system, Stephens Pass section, in Quaternary fault and fold database of the United States: U.S. Geological Survey website, http://earthquakes.usgs.gov/regional/qfaults, accessed 10/19/2008 01:15 AM.

Bryant, W.A., compiler, 2000f, Fault number 4, Surprise Valley fault, in Quaternary fault and fold database of the United States: U.S. Geological Survey website, http://earthquakes.usgs.gov/regional/qfaults, accessed 10/19/2008 01:20 AM.

Bryant, W.A., compiler, 2000g, Fault number 29a, Bartlett Springs fault system, Lake Mountain section, in Quaternary fault and fold database of the United States: U.S. Geological Survey website, http://earthquakes.usgs.gov/regional/qfaults, accessed 10/18/2008 07:06 PM.

Bryant, W.A., compiler, 2000h, Fault number 21, Almanor fault zone, in Quaternary fault and fold database of the United States: U.S. Geological Survey website, http://earthquakes.usgs.gov/regional/qfaults, accessed 10/18/2008 06:49 PM.

CalEnergy, 1998, Glass Mountain 31-17 temperature and pressure surveys: unpublished survey report.

California DONR, 1958, Geologic Map of California, Alturas Sheet, 1:250,000:

California Department of Natural Resources. 
Carrier, D. L., 1989a; Hydrothermal alteration and well lithologies for Glass Mountain Wells: GMF 68-8, GMF 31-17, and GMF 17A-6: unpublished Unocal Report UCA07.2701.

Carrier, D. L., 1989b, Glass Mountain borehole and well data: unpublished Unocal Report UCA05.0401.

Chiarabba, C., Amato, A., Evans, J.R., 1995, Variations on the NeHT high-resolution tomography method: a test of technique and results for Medicine Lake volcano, northern California: Journal of Geophysical Research, v. 100, p. 4035-4052.

Clausen, S., Nemčok, M., Moore, J., Hulen, J., and Bartley, J., 2006, Mapping Fractures in the Medicine Lake Geothermal System: Transactions, Geothermal Resources Council, v. 30, p. 383-386.

Cumming, W., and Mackie, R., 2007, MT Survey for Resources Assessment at the Glass Mountain KGRA: California Energy Commission, GRDDA Geothermal Resource Development Account, CEC-500-2007-xxx, p. 1-91.

Donnelly-Nolan, J.M., 1988, A magmatic model of Medicine Lake Volcano, California: Journal of Geophysical Research, v. 93, p. 4412-4420.

Donnelly-Nolan, J.M., 1990, Geology of Medicine Lake volcano, northern California Cascade range: Transactions, Geothermal Resources Council, v.14, p. 13951396.

Donnelly-Nolan, J.M., Champion, D.E., Miller, C.D., Grove, T.L., and Trimble, D.A., 1990, Post-11,000-year volcanism at Medicine Lake volcano, Cascade Range, northern California:

Journal of Geophysical Research, v. 95, p. 19,693-19,704.

Donnelly-Nolan, J.M., Grove, T.L., Lanphere, M.A., and Champion, D.E., 2008, Eruptive History and tectonic setting of Medicine Lake Volcano, a large rear-arc volcano in the southern Cascades: Journal of Volcanolgy and Geothermal Research, v. 177, p. 313-328.

Donnelly-Nolan, J.M., and Lanphere, M.A., 2005, Argon Dating at and near Medicine Lake Volcano, California: Results and Data: U.S. Geological Survey Open-File Report 2005-1416.

Donnelly-Nolan, J.M., Nathenson, M., Champion, D.E., Ramsey, D.W., Lowenstern, J.B., and Ewert, J.W., 2007, Volcano hazards assessment for Medicine Lake volcano, northern California: U.S. Geological Survey Scientific Investigations Report 2007-5174-A, p. 1-26. [http://pubs.usgs.gov/sir/2007/5174/a/]. 
Dzurisisn, D., Donnelly-Nolan, J.M., Evans, J.R., and Walter, S.R., 1991, Crustal subsidence, seismicity, and structure near Medicine Lake Volcano, California: Journal of Geophysical Research, v. 96, p. 16319-16333.

Dzurisisn, D., Poland, M.P., and Bürgmann, R., 2002, Steady subsidence of Medicine Lake volcano, northern California, revealed by repeated leveling surveys: Journal of Geophysical Research, v. 107(B12), 16 p.

Eichelberger, J.C., 1981, Mechanism of magma mixing at Glass Mountain, Medicine Lake Highland Volcano, California, guides to some volcanic Terranes in Washington, Idaho, Oregon, and Northern California: U.S.Geological Survey Circular 838.

Evans, J.R., and Zucca, J.J., 1988, Active high-resolution seismic tomography of compressional wave velocity and attenuation structure at Medicine Lake volcano, northernCalifornia Cascade Range: Journal of Geophysical Research, v. 93, p. 15016-15036.

Faulds, J.E., Christopher, D.H., and Nicholas, H.H., 2005, Kinematics of the Northern Walker Lane:An Incipient transform Fault along the Pacific-North American Plate Boundary: Geology, v.33, p. 505-508.

Finn, C., and Williams, D.L., 1982, Gravity evidence for a shallow intrusion under Medicine Lake Volcano, California: Geology, v. 10, p. 503-507.

Fuis, G.S., Zucca, J.J., Mooney, W.D., and Milkereit, B., 1987, A geologic interpretation of seismic-refraction results in northeastern California: Bulletin, Geological Society of America, v. 98, p. 53-65.

Hausback, B.P., 1984, Surficial Geology of the Medicine Lake Highland: unpublished Union Oil Company of California Report.

Glazner, A.F., Walker, J.D., Bartley, J.M., and Fletcher, J.M., 2002, Cenozoic evolution of the Mojave Block of Southern California: in Glazner, A.F., et al., eds., Geologic evolution of the Mojave Desert and southwestern Basin and Range: Geological Society of America Memoir 195, p. 19-41.

Gudmundsson, A, and Nilsen, K., 2006, Ring-faults in composite volcanoes: structures, models, and stress fields associated with their formation: Geological Society of London, Special Publications, v. 269, p. 83-108.

Hart, E.W., compiler, 1999a, Fault number 11, Grogan fault, in Quaternary fault and fold database of the United States: U.S. Geological Survey website, http://earthquakes.usgs.gov/regional/qfaults, accessed 10/18/2008 06:59 PM. 
Hart, E.W., compiler, 1999b, Fault number 12, Bald Mountain-Big Lagoon fault zone, in Quaternary fault and fold database of the United States: U.S. Geological Survey website, http://earthquakes.usgs.gov/regional/qfaults, accessed 10/18/2008 07:03 PM.

Hart, E.W., compiler, 1999c, Fault number 13, Mad River fault zone, in Quaternary fault and fold database of the United States: U.S. Geological Survey website, http://earthquakes.usgs.gov/regional/qfaults, accessed 10/18/2008 07:05 PM.

Hart, E.W., compiler, 1999d, Fault number 15, Little Salmon fault zone, in Quaternary fault and fold database of the United States: U.S. Geological Survey website, http://earthquakes.usgs.gov/regional/qfaults, accessed 10/18/2008 07:10 PM.

Hildreth, W., 2007, Quaternary magmatism in the Cascades; geologic perspectives: U.S. Geological Survey Professional Paper 1744, 125 p.

[http://pubs.usgs.gov/pp/pp1744/].

Hulen, Jeffrey B., 1984, Results of X-ray diffraction studies on 34 pulp samples: unpublished Union Geothermal Division, Union Oil Company of California Report.

Hulen, J.B., 1985a, X-ray diffraction study of Well 17A-6: unpublished Union Geothermal Division, Union Oil Company of California Report.

Hulen, J.B., 1985b, Analysis of 70 felsic- to mafic-composition volcanic rock cuttings samples by X-ray diffraction: unpublished Union Geothermal Division, Union Oil Company of California Report.

Hulen, J.B., and Lutz, S.J., 1999, Altered volcanic rocks as hydrologic seals on the geothermal system of Medicine Lake Volcano, California: Geothermal Resources Council Bulletin, v. 7, p. 217-222.

Jones, R., 1994, Sub-surface temperature survey for GMF 88-28: unpublished Pruett Industries, Inc. Report.

Konietzky, H. (ed.), 2004. Numerical Modeling of Discrete Materials in Geotechnical Engineering, Civil Engineering, and Earth Sciences: Taylor and Francis, London, UK, p. 1-318.

Lowenstern, J.B., Donnelly-Nolan, J.M., Wooden, J.L., and Charlier, B.L.A., 2003, Volcanism, plutonism, and hydrothermal alteration at Medicine Lake Volcano, California: Proceedings, Twenty-Eighth Workshop on Geothermal Reservoir Engineering, SGP-TR-173.

Lutz, Susan J., 1988a, Revised results of X-ray diffraction studies of the " 8 " series group: unpublished Unocal Geothermal Division, Unocal Corporation Report. 
Lutz, Susan J., 1988b, X-ray diffraction studies of the "17" series group: unpublished Unocal Geothermal Division, Unocal Corporation Report.

Lutz, Susan J., 1990, X-Ray diffraction studies of Well 13: unpublished Unocal Geothermal Division Report, Unocal Corporation Report.

Lutz, J.L., Hulen, J.B., and Schriener, A., 2000, Alteration, Geothermometry, and Granitoid Intrusions in Well GMF 31-17, Medicine Lake Volcano Geothermal System, California: Proceedings, Twenty-Fifth Workshop on Geothermal Reservoir Engineering, SGP-TR-165.

Moore, J.N., 2004, Predicting fracture characteristics in volcanic environments as a guide to locating enhanced geothermal system reservoirs: Department of Energy Project Narrative.

Nordquist, M., 1985, Updated geophysical interpretation of the Medicine Lake volcano: unpublishede Union Oil Company of California Report.

Nordquist, G.A., and Thompson, R.C., 1990, Integrated geophysical and geological interpretation of the Glass Mountain prospect, California: unpublished Unocal Report.

Nemčok, M., 2006, unpublished Medicine Lake volcano field notes.

Personius, S.F., compiler, 2002a, Fault number 1807, Mount Mazama ring faults, in Quaternary fault and fold database of the United States: U.S. Geological Survey website, http://earthquakes.usgs.gov/regional/qfaults, accessed 10/18/2008 07:31 PM.

Personius, S.F., compiler, 2002b, Fault number 1806, Newberry volcano ring faults, in Quaternary fault and fold database of the United States: U.S. Geological Survey website, http://earthquakes.usgs.gov/regional/qfaults, accessed 10/20/2008 10:11 PM.

Personius, S.F., compiler, 2002c, Fault number 843a, Klamath graben fault system, West Klamath Lake section, in Quaternary fault and fold database of the United States: U.S. Geological Survey website, http://earthquakes.usgs.gov/regional/qfaults, accessed 10/18/2008 07:29 PM.

Personius, S.F., compiler, 2002d, Fault number 828, Goose Lake graben faults, in Quaternary fault and fold database of the United States: U.S. Geological Survey website, http://earthquakes.usgs.gov/regional/qfaults, accessed 10/18/2008 06:15 PM. 
Personius, S.F., compiler, 2002e, Fault number 829a, Abert Rim fault, Lake Abert section, in Quaternary fault and fold database of the United States: U.S. Geological Survey website, http://earthquakes.usgs.gov/regional/qfaults, accessed 10/18/2008 06:18 PM.

Personius, S.F., compiler, 2002f, Fault number 830, Unnamed faults north of Abert Lake, in Quaternary fault and fold database of the United States: U.S. Geological Survey website, http://earthquakes.usgs.gov/regional/qfaults, accessed 10/18/2008 06:21 PM.

Personius, S.F., compiler, 2002g, Fault number 831a, Winter Rim fault system, Slide Mountain section, in Quaternary fault and fold database of the United States: U.S. Geological Survey website, http://earthquakes.usgs.gov/regional/qfaults, accessed 10/18/2008 06:22 PM.

Personius, S.F., compiler, 2002h, Fault number 831b, Winter Rim fault system, Winter Ridge section, in Quaternary fault and fold database of the United States: U.S. Geological Survey website, http://earthquakes.usgs.gov/regional/qfaults, accessed 10/18/2008 06:23 PM.

Personius, S.F., compiler, 2002i, Fault number 831c, Winter Rim fault system, Ana River section, in Quaternary fault and fold database of the United States: U.S. Geological Survey website, http://earthquakes.usgs.gov/regional/qfaults, accessed 10/18/2008 06:25 PM.

Personius, S.F., compiler, 2002j, Fault number 832, Faults east of Summer Lake, in Quaternary fault and fold database of the United States: U.S. Geological Survey website, http://earthquakes.usgs.gov/regional/qfaults, accessed 10/18/2008 06:27 PM.

Personius, S.F., compiler, 2002k, Fault number 839a, Chemult graben fault system, western section, in Quaternary fault and fold database of the United States: U.S. Geological Survey website, http://earthquakes.usgs.gov/regional/qfaults, accessed 10/18/2008 06:29 PM.

Personius, S.F., compiler, 20021, Fault number 840, Faults on the Modoc Plateau, in Quaternary fault and fold database of the United States: U.S. Geological Survey website, http://earthquakes.usgs.gov/regional/qfaults, accessed 10/18/2008 06:31 PM.

Personius, S.F., compiler, 2002m, Fault number 843b, Klamath graben fault system, East Klamath Lake section, in Quaternary fault and fold database of the United States: U.S. Geological Survey website, http://earthquakes.usgs.gov/regional/qfaults, accessed 10/18/2008 06:33 PM. 
Personius, S.F., compiler, 2002n, Fault number 843c, Klamath graben fault system, South Klamath Lake section, in Quaternary fault and fold database of the United States: U.S. Geological Survey website, http://earthquakes.usgs.gov/regional/qfaults, accessed 10/18/2008 06:35 PM.

Personius, S.F., compiler, 2002o, Fault number 819, Brothers fault zone, in Quaternary fault and fold database of the United States: U.S. Geological Survey website, http://earthquakes.usgs.gov/regional/qfaults, accessed 10/18/2008 04:41 PM.

Personius, S.F., compiler, 2002p, Fault number 821, Donner und Blitzen fault, in Quaternary fault and fold database of the United States: U.S. Geological Survey website, http://earthquakes.usgs.gov/regional/qfaults, accessed 10/18/2008 04:44 PM.

Personius, S.F., compiler, 2002q, Fault number 822, Unnamed fault near V Lake, in Quaternary fault and fold database of the United States: U.S. Geological Survey website, http://earthquakes.usgs.gov/regional/qfaults, accessed 10/18/2008 04:47 PM.

Personius, S.F., compiler, 2002r, Fault number 823, Unnamed fault near Dry Valley, in Quaternary fault and fold database of the United States: U.S. Geological Survey website, http://earthquakes.usgs.gov/regional/qfaults, accessed 10/18/2008 04:51 PM.

Personius, S.F., compiler, 2002s, Fault number 824a, Unnamed Catlow Valley faults, Catlow Valley section, in Quaternary fault and fold database of the United States: U.S. Geological Survey website, http://earthquakes.usgs.gov/regional/qfaults, accessed 10/18/2008 05:18 PM.

Personius, S.F., compiler, 2002t, Fault number 824b, Unnamed Catlow Valley faults, Hawksy Walksy Valley section, in Quaternary fault and fold database of the United States: U.S. Geological Survey website, http://earthquakes.usgs.gov/regional/qfaults, accessed 10/18/2008 05:20 PM.

Personius, S.F., compiler, 2002u, Fault number 829b, Abert Rim fault, northern section, in Quaternary fault and fold database of the United States: U.S. Geological Survey website, http://earthquakes.usgs.gov/regional/qfaults, accessed 10/18/2008 06:19 PM.

Personius, S.F., compiler, 2002v, Fault number 856b, Steens fault zone, Mann Lake section, in Quaternary fault and fold database of the United States: U.S. Geological Survey website, http://earthquakes.usgs.gov/regional/qfaults, accessed 10/18/2008 05:35 PM. 
Personius, S.F., compiler, 2002w, Fault number 856c, Steens fault zone, Alvord section, in Quaternary fault and fold database of the United States: U.S. Geological Survey website, http://earthquakes.usgs.gov/regional/qfaults, accessed 10/18/2008 05:37 PM.

Personius, S.F., compiler, 2002x, Fault number 856d, Steens fault zone, Fields Section, in Quaternary fault and fold database of the United States: U.S. Geological Survey website, http://earthquakes.usgs.gov/regional/qfaults, accessed 10/18/2008 05:41 PM.

Personius, S.F., compiler, 2002y, Fault number 856e, Steens fault zone, Tum Tum section, in Quaternary fault and fold database of the United States: U.S. Geological Survey website, http://earthquakes.usgs.gov/regional/qfaults, accessed 10/18/2008 05:55 PM.

Personius, S.F., compiler, 2002z, Fault number 857, Mickey Basin faults, in Quaternary fault and fold database of the United States: U.S. Geological Survey website, http://earthquakes.usgs.gov/regional/qfaults, accessed 10/18/2008 05:58 PM.

Personius, S.F., compiler, 2002aa, Fault number 858, Tule Springs Rims fault, in Quaternary fault and fold database of the United States: U.S. Geological Survey website, http://earthquakes.usgs.gov/regional/qfaults, accessed 10/18/2008 06:00 PM.

Personius, S.F., compiler, 2002ab, Fault number 1800, Unnamed Sheepshead Mountains fault, in Quaternary fault and fold database of the United States: U.S. Geological Survey website, http://earthquakes.usgs.gov/regional/qfaults, accessed 10/18/2008 06:03 PM.

Personius, S.F., compiler, 2002ac, Fault number 844, Sky Lakes fault zone, in Quaternary fault and fold database of the United States: U.S. Geological Survey website, http://earthquakes.usgs.gov/regional/qfaults, accessed 10/19/2008 01:33 AM.

Personius, S.F., and Lidke, D.J., compilers, 2002, Fault number 827c, Warner Valley faults, Coleman Valley section, in Quaternary fault and fold database of the United States: U.S. Geological Survey website, http://earthquakes.usgs.gov/regional/qfaults, accessed 10/18/2008 01:47 PM.

Personius, S.F., and Sawyer, T.L., compilers, 2002a, Fault number 827a, Warner Valley faults, East Warner Valley section, in Quaternary fault and fold database of the United States: U.S. Geological Survey website, http://earthquakes.usgs.gov/regional/qfaults, accessed 10/18/2008 05:22 PM. 
Personius, S.F., and Sawyer, T.L., compilers, 2002b, Fault number 827b, Warner Valley faults, West Warner Valley section, in Quaternary fault and fold database of the United States: U.S. Geological Survey website, http://earthquakes.usgs.gov/regional/qfaults, accessed 10/18/2008 05:29 PM.

Personius, S.F., and Sawyer, T.L., compilers, 2002c, Fault number 856f, Steens fault zone, Denio Section, in Quaternary fault and fold database of the United States: U.S. Geological Survey website, http://earthquakes.usgs.gov/regional/qfaults, accessed 10/18/2008 05:57 PM.

Personius, S.F., and Sawyer, T.L., compilers, 2002d, Fault number 826, Unnamed Guano Valley faults, in Quaternary fault and fold database of the United States: U.S. Geological Survey website, http://earthquakes.usgs.gov/regional/qfaults, accessed 10/18/2008 01:42 PM.

Petit, J.P., 1987, Criteria for the sense of movement on fault surfaces in brittle rocks: Journal of Structural Geology, v. 9, p. 597-608.

Poland, M., Bürgmann, R., Dzurisin, D., Lisowski, M., Masterlark, T., Owen, S., and Fink, J., 2006, Constraints on the mechanism of long-term steady subsidence at Medicine Lake volcano, northern California, from GPS, leveling, and InSAR: Journal of Volcanolgy and Geothermal Research, v. 150, p. 55-78.

Ritter, J.R., and Evans, J.R., 1997, Deep structure of Medicine Lake volcano, California: Tectonophysics, v. 275, p. 221-241.

Sawyer, T.L., compiler, 1995a, Fault number 8, McArthur fault zone, in Quaternary fault and fold database of the United States: U.S. Geological Survey website, http://earthquakes.usgs.gov/regional/qfaults, accessed 10/18/2008 06:45 PM.

Sawyer, T.L., compiler, 1995b, Fault number 9, Hat Creek fault zone, in Quaternary fault and fold database of the United States: U.S. Geological Survey website, http://earthquakes.usgs.gov/regional/qfaults, accessed 10/18/2008 06:47 PM.

Sawyer, T.L., compiler, 1995c, Fault number 7, Pittville fault, in Quaternary fault and fold database of the United States: U.S. Geological Survey website, http://earthquakes.usgs.gov/regional/qfaults, accessed 10/18/2008 06:43 PM.

Sawyer, T.L., compiler, 1995d, Fault number 10, Rocky Ledge fault, in Quaternary fault and fold database of the United States: U.S. Geological Survey website, http://earthquakes.usgs.gov/regional/qfaults, accessed 10/18/2008 06:49 PM.

Sawyer, T.L., compiler, 1995e, Fault number 24, Fort Sage fault, in Quaternary fault and fold database of the United States: U.S. Geological Survey website, http://earthquakes.usgs.gov/regional/qfaults, accessed 10/18/2008 06:52 PM. 
Sawyer, T.L., compiler, 1998a, Fault number 1463, Unnamed fault in Coppersmith Hills, in Quaternary fault and fold database of the United States: U.S. Geological Survey website, http://earthquakes.usgs.gov/regional/qfaults, accessed 10/18/2008 01:50 PM.

Sawyer, T.L., compiler, 1998b, Fault number 1464, Hays Canyon Range fault zone, in Quaternary fault and fold database of the United States: U.S. Geological Survey website, http://earthquakes.usgs.gov/regional/qfaults, accessed 10/18/2008 01:51 PM.

Sawyer, T.L., compiler, 1998c, Fault number 1465, Unnamed fault zone in the Hays Canyon Range, in Quaternary fault and fold database of the United States: U.S. Geological Survey website, http://earthquakes.usgs.gov/regional/qfaults, accessed 10/18/2008 01:52 PM.

Sawyer, T.L., compiler, 1998d, Fault number 1466, Vya fault, in Quaternary fault and fold database of the United States: U.S. Geological Survey website, http://earthquakes.usgs.gov/regional/qfaults, accessed 10/18/2008 01:54 PM.

Sawyer, T.L., compiler, 1998e, Fault number 1468, Unnamed fault southeast of Mosquito Valley, in Quaternary fault and fold database of the United States: U.S. Geological Survey website, http://earthquakes.usgs.gov/regional/qfaults, accessed 10/18/2008 01:55 PM.

Sawyer, T.L., compiler, 1998f, Fault number 1470, Unnamed fault zone in Long Valley, in Quaternary fault and fold database of the United States: U.S. Geological Survey website, http://earthquakes.usgs.gov/regional/qfaults, accessed 10/18/2008 01:56 PM.

Sawyer, T.L., compiler, 1998g, Fault number 1472, Duck Flat fault, in Quaternary fault and fold database of the United States: U.S. Geological Survey website, http://earthquakes.usgs.gov/regional/qfaults, accessed 10/18/2008 01:57 PM.

Sawyer, T.L., compiler, 1998h, Fault number 1474, Unnamed fault zone near Bordwell Spring, in Quaternary fault and fold database of the United States: U.S. Geological Survey website, http://earthquakes.usgs.gov/regional/qfaults, accessed 10/18/2008 01:58 PM.

Sawyer, T.L., compiler, 1998i, Fault number 1475, Unnamed fault near Pinto Peak, in Quaternary fault and fold database of the United States: U.S. Geological Survey website, http://earthquakes.usgs.gov/regional/qfaults, accessed 10/18/2008 02:00 PM. 
Sawyer, T.L., compiler, 1998j, Fault number 1476, Unnamed faults near Massacre Lake, in Quaternary fault and fold database of the United States: U.S. Geological Survey website, http://earthquakes.usgs.gov/regional/qfaults, accessed 10/18/2008 02:00 PM.

Sawyer, T.L., compiler, 1998k, Fault number 1479, Unnamed faults near Rock Spring Table, in Quaternary fault and fold database of the United States: U.S. Geological Survey website, http://earthquakes.usgs.gov/regional/qfaults, accessed 10/18/2008 02:03 PM.

Sawyer, T.L., compiler, 19981, Fault number 1480, Unnamed fault zone near Badger Mountain, in Quaternary fault and fold database of the United States: U.S. Geological Survey website, http://earthquakes.usgs.gov/regional/qfaults, accessed 10/18/2008 02:05 PM.

Sawyer, T.L., compiler, 1998m, Fault number 1481, Unnamed fault near Hanging Rock Canyon, in Quaternary fault and fold database of the United States: U.S. Geological Survey website, http://earthquakes.usgs.gov/regional/qfaults, accessed 10/18/2008 02:06 PM.

Sawyer, T.L., compiler, 1998n, Fault number 1482, Unnamed fault near High Rock Canyon, in Quaternary fault and fold database of the United States: U.S. Geological Survey website, http://earthquakes.usgs.gov/regional/qfaults, accessed 10/18/2008 02:07 PM.

Sawyer, T.L., compiler, 1998o, Fault number 1483, Unnamed faults near Hog Ranch Creek, in Quaternary fault and fold database of the United States: U.S. Geological Survey website, http://earthquakes.usgs.gov/regional/qfaults, accessed 10/18/2008 02:08 PM.

Sawyer, T.L., compiler, 1998p, Fault number 1486, Unnamed faults in northern Black Rock Desert, in Quaternary fault and fold database of the United States: U.S. Geological Survey website, http://earthquakes.usgs.gov/regional/qfaults, accessed 10/18/2008 02:14 PM.

Sawyer, T.L., compiler, 1998q, Fault number 1487, Unnamed faults southeast of Fivemile Flat, in Quaternary fault and fold database of the United States: U.S. Geological Survey website, http://earthquakes.usgs.gov/regional/qfaults, accessed 10/18/2008 02:16 PM.

Sawyer, T.L., compiler, 1998r, Fault number 1488, McGee Mountain fault zone, in Quaternary fault and fold database of the United States: U.S. Geological Survey website, http://earthquakes.usgs.gov/regional/qfaults, accessed 10/18/2008 02:17 PM. 
Sawyer, T.L., compiler, 1998s, Fault number 1491, Unnamed fault zone southwest of Pine Forest Range, in Quaternary fault and fold database of the United States: U.S. Geological Survey website, http://earthquakes.usgs.gov/regional/qfaults, accessed 10/18/2008 02:20 PM.

Sawyer, T.L., compiler, 1998t, Fault number 1492, Unnamed faults southeast Pine Forest Range, in Quaternary fault and fold database of the United States: U.S. Geological Survey website, http://earthquakes.usgs.gov/regional/qfaults, accessed 10/18/2008 02:22 PM.

Sawyer, T.L., compiler, 1998u, Fault number 1493, Unnamed faults west of Black Rock Desert, in Quaternary fault and fold database of the United States: U.S. Geological Survey website, http://earthquakes.usgs.gov/regional/qfaults, accessed 10/18/2008 02:23 PM.

Sawyer, T.L., compiler, 1998v, Fault number 1495a, Eastern Pine Forest Range fault zone, northern section, in Quaternary fault and fold database of the United States: U.S. Geological Survey website, http://earthquakes.usgs.gov/regional/qfaults, accessed 10/18/2008 02:26 PM.

Sawyer, T.L., compiler, 1998w, Fault number 1495b, Eastern Pine Forest Range fault zone, southern section, in Quaternary fault and fold database of the United States: U.S. Geological Survey website, http://earthquakes.usgs.gov/regional/qfaults, accessed 10/18/2008 02:27 PM.

Sawyer, T.L., compiler, 1998x, Fault number 1496, Eastern Bilk Creek Mountains fault zone, in Quaternary fault and fold database of the United States: U.S. Geological Survey website, http://earthquakes.usgs.gov/regional/qfaults, accessed 10/18/2008 02:28 PM.

Sawyer, T.L., compiler, 1998y, Fault number 1497, Unnamed fault zone southwest of Bilk Creek Mountains, in Quaternary fault and fold database of the United States: U.S. Geological Survey website, http://earthquakes.usgs.gov/regional/qfaults, accessed 10/18/2008 02:30 PM.

Sawyer, T.L., compiler, 1998z, Fault number 1498, Eastern Jackson Mountains fault zone, in Quaternary fault and fold database of the United States: U.S. Geological Survey website, http://earthquakes.usgs.gov/regional/qfaults, accessed 10/18/2008 02:31 PM.

Sawyer, T.L., compiler, 1998aa, Fault number 1499, Unnamed fault zone southeastern Jackson Mountains, in Quaternary fault and fold database of the United States: U.S. Geological Survey website, http://earthquakes.usgs.gov/regional/qfaults, accessed 10/18/2008 02:32 PM. 
Sawyer, T.L., compiler, 1998ab, Fault number 1501a, Montana Mountains/Desert Valley fault zone, northern section, in Quaternary fault and fold database of the United States: U.S. Geological Survey website, http://earthquakes.usgs.gov/regional/qfaults, accessed 10/18/2008 02:35 PM.

Sawyer, T.L., compiler, 1998ac, Fault number 1501b, Montana Mountains/Desert Valley fault zone, southern section, in Quaternary fault and fold database of the United States: U.S. Geological Survey website, http://earthquakes.usgs.gov/regional/qfaults, accessed 10/18/2008 02:37 PM.

Sawyer, T.L., compiler, 1998ad, Fault number 1502, Unnamed faults in the northern Double H Mountains, in Quaternary fault and fold database of the United States: U.S. Geological Survey website, http://earthquakes.usgs.gov/regional/qfaults, accessed 10/18/2008 02:38 PM.

Sawyer, T.L., compiler, 1998ae, Fault number 1503, Unnamed fault zone east of Trout Creek Mountains, in Quaternary fault and fold database of the United States: U.S. Geological Survey website, http://earthquakes.usgs.gov/regional/qfaults, accessed 10/18/2008 02:40 PM.

Sawyer, T.L., compiler, 1999a, Fault number 1478, Unnamed faults near Gooch Lake, in Quaternary fault and fold database of the United States: U.S. Geological Survey website, http://earthquakes.usgs.gov/regional/qfaults, accessed 10/18/2008 02:01 PM.

Sawyer, T.L., compiler, 1999b, Fault number 1494, Jackson Mountains fault zone, in Quaternary fault and fold database of the United States: U.S. Geological Survey website, http://earthquakes.usgs.gov/regional/qfaults, accessed 10/18/2008 02:24 PM.

Sawyer, T.L., and Adams, K.D., compilers, 1998a, Fault number 1484, Unnamed faults along western Calico Mountains, in Quaternary fault and fold database of the United States: U.S. Geological Survey website, http://earthquakes.usgs.gov/regional/qfaults, accessed 10/18/2008 02:10 PM.

Sawyer, T.L., and Adams, K.D., compilers, 1998b, Fault number 1485, Black Rock fault zone, in Quaternary fault and fold database of the United States: U.S. Geological Survey website, http://earthquakes.usgs.gov/regional/qfaults, accessed 10/18/2008 02:11 PM.

Sawyer, T.L., and Adams, K.D., compilers, 1999a, Fault number 1606, Terraced Hills fault zone, in Quaternary fault and fold database of the United States: U.S. Geological Survey website, http://earthquakes.usgs.gov/regional/qfaults, accessed 10/18/2008 03:24 PM. 
Sawyer, T.L., and Adams, K.D., compilers, 1999b, Fault number 1500, Unnamed faults bounding Blue Mountain, in Quaternary fault and fold database of the United States: U.S. Geological Survey website, http://earthquakes.usgs.gov/regional/qfaults, accessed 10/18/2008 02:33 PM.

Sawyer, T.L., and Adams, K.D., compilers, 1999c, Fault number 1604, Alkali Flat fault, in Quaternary fault and fold database of the United States: U.S. Geological Survey website, http://earthquakes.usgs.gov/regional/qfaults, accessed 10/18/2008 03:18 PM.

Sawyer, T.L., and Adams, K.D., compilers, 1999d, Fault number 1607, Eastern Pyramid Lake fault, in Quaternary fault and fold database of the United States: U.S. Geological Survey website, http://earthquakes.usgs.gov/regional/qfaults, accessed 10/18/2008 03:28 PM.

Sawyer, T.L., and Adams, K.D., compilers, 1999e, Fault number 1609, Unnamed faults near Squaw Valley, in Quaternary fault and fold database of the United States: U.S. Geological Survey website, http://earthquakes.usgs.gov/regional/qfaults, accessed 10/18/2008 03:36 PM.

Sawyer, T.L., and Adams, K.D., compilers, 1999f, Fault number 1611, Eastern Granite Range fault, in Quaternary fault and fold database of the United States: U.S. Geological Survey website, http://earthquakes.usgs.gov/regional/qfaults, accessed 10/18/2008 03:41 PM.

Sawyer, T.L., Adams, K.D., compilers, 1999g, Fault number 1612, Gerlach fault zone, in Quaternary fault and fold database of the United States: U.S. Geological Survey website, http://earthquakes.usgs.gov/regional/qfaults, accessed 10/18/2008 03:42 PM.

Sawyer, T.L., and Adams, K.D., compilers, 1999h, Fault number 1613, San Emidio fault zone, in Quaternary fault and fold database of the United States: U.S. Geological Survey website, http://earthquakes.usgs.gov/regional/qfaults, accessed 10/18/2008 03:45 PM.

Sawyer, T.L., and Adams, K.D., compilers, 1999i, Fault number 1614, Nightingale Mountains fault zone, in Quaternary fault and fold database of the United States: U.S. Geological Survey website, http://earthquakes.usgs.gov/regional/qfaults, accessed 10/18/2008 03:46 PM.

Sawyer, T.L., and Adams, K.D., compilers, 1999j, Fault number 1615, Unnamed fault zone between Kumiva and Sage Hen Valleys, in Quaternary fault and fold database of the United States: U.S. Geological Survey website, http://earthquakes.usgs.gov/regional/qfaults, accessed 10/18/2008 03:48 PM. 
Sawyer, T.L., and Adams, K.D., compilers, 1999k, Fault number 1616, Unnamed fault zone on east side of Selenite Range, in Quaternary fault and fold database of the United States: U.S. Geological Survey website, http://earthquakes.usgs.gov/regional/qfaults, accessed 10/18/2008 03:49 PM.

Sawyer, T.L., and Adams, K.D., compilers, 19991, Fault number 1617, Selenite Range fault zone, in Quaternary fault and fold database of the United States: U.S. Geological Survey website, http://earthquakes.usgs.gov/regional/qfaults, accessed 10/18/2008 03:50 PM.

Sawyer, T.L., and Adams, K.D., compilers, 1999m, Fault number 1619, Kumiva Valley fault zone, in Quaternary fault and fold database of the United States: U.S. Geological Survey website, http://earthquakes.usgs.gov/regional/qfaults, accessed 10/18/2008 04:01 PM.

Sawyer, T.L., and Adams, K.D., compilers, 1999n, Fault number 1620, Unnamed fault zone along Bluewing Mountains, in Quaternary fault and fold database of the United States: U.S. Geological Survey website, http://earthquakes.usgs.gov/regional/qfaults, accessed 10/18/2008 04:02 PM.

Sawyer, T.L., and Adams, K.D., compilers, 1999o, Fault number 1621, Unnamed faults along Sahwave Mountains, in Quaternary fault and fold database of the United States: U.S. Geological Survey website, http://earthquakes.usgs.gov/regional/qfaults, accessed 10/18/2008 04:03 PM.

Sawyer, T.L., and Adams, K.D., compilers, 1999p, Fault number 1622, Granite Springs Valley fault zone, in Quaternary fault and fold database of the United States: U.S. Geological Survey website, http://earthquakes.usgs.gov/regional/qfaults, accessed 10/18/2008 04:04 PM.

Sawyer, T.L., and Adams, K.D., compilers, 1999q, Fault number 1623, Unnamed fault zone near The Lava Beds, in Quaternary fault and fold database of the United States: U.S. Geological Survey website, http://earthquakes.usgs.gov/regional/qfaults, accessed 10/18/2008 04:05 PM.

Sawyer, T.L., and Adams, K.D., compilers, 1999r, Fault number 1624, The Lava Beds fault, in Quaternary fault and fold database of the United States: U.S. Geological Survey website, http://earthquakes.usgs.gov/regional/qfaults, accessed 10/18/2008 04:06 PM.

Sawyer, T.L., and Adams, K.D., compilers, 1999s, Fault number 1625, Unnamed fault zone near Sheep Spring, in Quaternary fault and fold database of the United States: U.S. Geological Survey website, http://earthquakes.usgs.gov/regional/qfaults, accessed 10/18/2008 04:07 PM. 
Sawyer, T.L., and Bryant, W.A., compilers, 1995, Fault number 5, Likely fault zone, in Quaternary fault and fold database of the United States: U.S. Geological Survey website, http://earthquakes.usgs.gov/regional/qfaults, accessed 10/18/2008 06:39 PM.

Sawyer, T.L., Adams, K.D., and Bryant, W.A., compilers, 1999, Fault number 1605, Warm Springs Valley fault zone, in Quaternary fault and fold database of the United States: U.S. Geological Survey website, http://earthquakes.usgs.gov/regional/qfaults, accessed 10/18/2008 03:20 PM.

Sawyer, T.L., and Personius, S.F., compilers, 2003, Fault number 1490, East Pueblo Valley fault zone, in Quaternary fault and fold database of the United States: U.S. Geological Survey website, http://earthquakes.usgs.gov/regional/qfaults, accessed 10/18/2008 06:01 PM.

Smith, J.G., and Donnelly-Nolan, J.M., 2005, Quantitative analysis of 0-2 Ma volcanic vent distribution in space, time, and composition centered on Medicine Lake volcano, northern California, USA: Eos, Transactions American Geophysical Union, v. 86, Fall Meeting Supplement, Abstract V53B-1563.

Stark, M., 2005, Medicine Lake logs and autocad files for Joe Moore: unpublished Calpine Corporation data files.

Toulokian, Y.S., Judd, W.R., and Roy, R.F., 1981, Physical properties of rocks and minerals: McGraw-Hill, New York.

Union Geothermal Division, 1975, Glass Mountain Prospect fault and lineament map, 1:63,360: Union Oil Company.

USGS, 1971, Geologic Map of Medicine Lake Volcano, California, 1:62,500: U.S. Geological Survey, Washington, D.C.

USGS, 1988a, Little Glass Mountain, California, 1:24,000, 7.5 Minute Series (Topographic): U.S. Geological Survey, Reston, Va.

USGS, 1988b, Bonita Butte Quadrangle, California, 1:24,000, 7.5 Minute Series (Topographic): U.S. Geological Survey, Reston, Va.

USGS, 1988c, Schonchin Butte Quadrangle, California, 1:24,000, 7.5 Minute Series (Topographic): U.S. Geological Survey, Reston, Va.

USGS, 1993, Medicine Lake Quadrangle, California, 1:24,000, 7.5 Minute Series (Topographic): U.S. Geological Survey, Reston, Va. 
Van Alstine, D.R., 2006, Paleomagnetic orientation of cores from four Medicine Lake wells: 88-28, 28-32,14-23, and 87-13: unpublished Applied Paelomagnetics Inc. Report.

Van Alstine, D.R., 2007, Paleomagnetic orientation of $2^{\text {nd }}$ batch of cores from four Medicine Lake wells: 88-28, 28-32, 14-23, 87-13, and 62-21: unpublished Applied Paelomagnetics Inc. Report.

Van Alstine, D. R., and Butterworth, J. E., 2002, Paleomagnetic core orientation helps determine the sedimentological, paleostress, and fluid-migration history in the Maracaibo Basin, Venezuela: Core Workshop for I Congreso Virtual de Sedimentología.

Wesnousky, S.G., 2005, The San Andreas and Walker Lane fault systems, western North America: transpression, transtension, cumulative slip and the structural evolution of a major transform plate boundary: Journal of Structural Geology, v. 27, p. 1505-1512.

Wood, A. and Kienle, J., 1990, Volcanoes of North America: United States and Canada (Contribution by Julie Donnelly-Nolan): Cambridge University Press, 354 p., p. 212-214. 
